Acta Cryst. (1992). A48, 353-405

\title{
International Union of Crystallography Fifteenth General Assembly and International Congress of Crystallography Bordeaux, France, 19-28 July 1990
}

Table of Contents

Introduction and Opening Ceremony . . . . . . 353

Fifteenth International Congress ........ 354

Minutes of the Fifteenth General Assembly

Introduction and list of delegates

First Session, Friday 20 July 1990, 7.35 p.m.

(1) Introductory remarks by the President . . . . . 355

(2) Procedural matters . . . . . . . . . 355

(3) Approval of the Agenda . . . . . . . . . . . 355

(4) Change in nature of the UK National Committee for Crystallography ...........

(5) Approval of the Minutes of the Fourteenth General Assembly . . . . . . . . . . . . .

(6) Approval of the Minutes of the Extraordinary General Assembly, London, England, 19 December 1989 . . . . E

(7) Report of the Executive Committee . . . . . . . 355

(8) Financial Report ............. 355

(9) Ewald Prize . . . . . . . . . . . . . . . . . . . . 356

(10) Commission on Journals . . . . . . . . . 356

(11) Commission on International Tables . . . . . . 356

(12) Commission on Structure Reports . . . . . . . . 356

(13) Working Party on Crystallographic Information . 356

(14) Reports of the non-publishing Commissions . . . 356

(15) Ad interim Commission on Modulated Structures, Polytypes and Quasi-crystals . . . . . . . .

(16) Proposal to establish a Commission on Synchrotron Radiation .............

(17) Determination of the number of elected members of each Commission ............

Second Session, Saturday 21 July 1990, 7.35 p.m.

(18) Reports of representatives on Scientific and Regional Associates ................

(19) Application by the American Crystallographic Association (ACA) to become a Regional Associate

(20) Reports of representatives on bodies not belonging to the Union .........................

(21) Sponsorship of meetings: Sub-committee on the Union Calendar ............

(22) IUCr/Oxford University Press Book Series . . .

(23) Determination of the general policy and the timetable for the period to the Sixteenth General Assembly

(24) Preliminary consideration of activities for the period

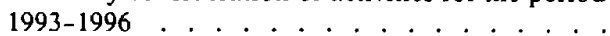

(25) Bud

(26) Confirmation of the date and place of the Sixteenth General Assembly . . . . . . . . . .

(27) Preliminary consideration of the date and place of the Seventeenth General Assembly . . . . 359

Third Session, Wednesday 25 July 1990, 7.30 p.m.

(28) Confirmation of the appointments of the Editors of the publications of the Union .......

(29) Election of Chairmen and members of Commissions

(30) Election of representatives on bodies not belonging to the Union and on Regional and Scientific Associates . . . . . . . . . . . . 359

(31) Election of Officers of the Union . . . . . . 359

Closing Ceremony, Saturday 28 July 1990

Annex I: Appendices to the Agenda of the Fifteenth General Assembly

(A) Report of the Executive Committee . . . . . . . 361

(B) Financial Report . . . . . . . . . . . 362

(C) Ewald Prize . . . . . . . . . . . . . . . 369

(D) Reports of the Commissions of the Union . . . 370

(E) Working Party on Crystallographic Information . 379

(F) Reports of the representatives on Scientific and Regional Associates . . . . . . . . . 380

(G) Reports of the representatives on bodies not belonging to the Union ...........

(H) Sponsorship of meetings: Sub-committee on the Union Calendar ...........

(I) IUCr/Oxford University Press Book Series . . .

(J) Budget estimates for the period to the Sixteenth General Assembly: determination of the unit contribution

Annex II: Statutes and By-Laws of the International Union of Crystallography ..... 389

Annex III: Committees, Commissions and representatives on Regional and Scientific Associates and bodies not belonging to the Union ....

Annex IV: Adhering Bodies and National Committees for Crystallography . .

402

\section{Introduction and Opening Ceremony}

By invitation of the Association Française de Cristallographie and' the Académie des Sciences, the Fifteenth General Assembly and International Congress of Crystal- lography were held on the campus of the three universities of Bordeaux, France, 19-28 July 1990.

The meetings were attended by 1852 scientists and 249 accompanying members from France and the following 45 countries: Algeria, Australia, Austria, Belgium, Brazil, 
Bulgaria, Canada, Chile, People's Republic of China, Czechoslovakia, Denmark, Arab Republic of Egypt, Finland, German Democratic Republic, Federal Republic of Germany, Greece, Hungary, India, Iraq, Israel, Italy, Japan, Korea, Libya, Mexico, Netherlands, New Zealand, Norway, Oman, Poland, Portugal, Romania, South Africa, Spain, Sweden, Switzerland, Taiwan, Tunisia, Turkey, UK, USA, USSR, Venezuela, Vietnam, Yugoslavia.

The General Assembly and Congress were opened on the afternoon of 19 July at the Palais des Sports in the centre of Bordeaux. Dr M. Hospital, Chairman of the Organizing Committee, chaired the ceremony. The welcoming addresses and the opening address by Professor $M$. NARDELLI, President of the IUCr, were followed by the Congress Discourse by Professor A. GUINiER. The Ewald Prize was presented to Professor B. K. VAINSHTEIN. After a short interval there was a performance of Beethoven's Ninth Symphony by the Orchestre National BordeauxAquitaine. The evening ended with a reception at the Parc Peixotto in Talence, near the university campus which was the site of the Congress.

\section{Fifteenth International Congress}

\section{Scientific programme}

Twenty Main Lectures and 52 Microsymposia and Open Commission Meetings were held during the morning sessions. The afternoons were reserved for poster sessions, with discussion sessions in the late afternoons to discuss the results presented in the posters and to extend the discussions on the Microsymposia. The 1600 abstracts received were all typeset and the figures scanned so that the published book of Collected Abstracts was prepared entirely by computer. These abstracts also appeared as a Supplement to Acta Crystallographica, Volume A46, dated 1 July 1990.

\section{Exhibitions and computer display}

A commercial exhibition, a book exhibition and a computer display were held in the Sports Hall, which was also used for all the poster sessions. There was also an exhibition of items of historical interest, including instruments related to the work of French crystallographers, to mark 200 years of crystallography in France.

\section{Social events}

In addition to the opening reception, there was a banquet in a large hall in the port of Bordeaux, a Congress excursion to vineyards and a farewell gathering after the close of the meeting. A more extensive social programme was arranged for those accompanying the Congress participants.

\section{Minutes of the Fifteenth General Assembly}

These Minutes have been prepared by J. N. King, Executive Secretary, under the authority of A. I. Hordvik, General Secretary and Treasurer of the IUCr and Secretary of the General Assembly.

\section{Introduction and list of delegates}

Sessions of the General Assembly were held on the evenings of Friday 20 July, Saturday 21 July and Wednesday $25 \mathrm{July}$. It was not found necessary to meet on Saturday 28 July, as originally planned. The following attendance list gives the names of official delegates appointed by the Adhering Bodies and of the alternates who substituted at one or more sessions. Dates of attendance are given in parentheses for those who were not present at every session. The names are listed by the countries to which the respective Adhering Bodies belong, and the number of votes of the Adhering Body is given in parentheses after the name of the country. The names of the Chairmen of the delegations are printed in bold type where they are known; those of alternates are marked by an asterisk. There were no delegates from Argentina, Chile or Mexico.

Australia (3): D. J. M. Bevan, H. C. Freeman, J. W. White. Austria (1): A. Preisinger.

Belgium (2): G. H. Evrard, G. S. D. King (20 and 21 July), J. Kuypers* (25 July).

Brazil (3): Y. Mascarenhas (21 and 25 July), I. Torriani (21 and 25 July).

Bulgaria (1): J. Macíček.

Canada (3): G. Bushnell, Y. Le Page, J. Trotter.

China, People's Republic of (4): J.-l. Huang, D.-c. Liang (20 and 21 July), M.-c. Shao, C.-t. Ye.

Czechoslovakia (1): K. Huml.

Denmark (1): B. Lebech.

Egypt (1): M. S. Ahmed.

Finland (1): T. Paakkari.

France (4): B. Capelle, Y. Epelboin, M. Frey* (25 July), M. Hospital (21 July), M. Marezio, J. Protas* (20 July). German Democratic Republic (1): P. Paufler.

Germany, Federal Republic of (4): J. Felsche* (21 July), K. F. Fischer, H. Fuess* (20 and 25 July), E. Koch $(20$ and 25 July), B. Krebs (20 and 21 July), E. Tillmanns (21 and 25 July).

Hungary (1): K. Simon.

India (2): G. R. Desiraju, S. P. Sen Gupta (20 and 25 July). Israel (1): J. Bernstein* (20 July), F. H. Herbstein (21 and $25 \mathrm{July})$.

Italy (3): A. Chiesi Villa, G. Filippini, A. Gavezzotti* (21 and 25 July).

Japan (4): T. Ashida (20 and 21 July), J. Harada, F. Marumo* (25 July), Y. Ohashi* (21 July), M. Tanaka (20 and 25 July), M. Tokonami.

Netherlands (2): D. Feil, J. Kroon.

New Zealand (1): W. T. Robinson.

Norway (1): B. F. Pedersen* (25 July).

Poland (1): R. Kubiak.

Portugal (1): L. Alte da Veiga.

South Africa (2); J. C. A. Boeyens, L. R. Nassimbeni.

Spain (3): J. M. Amigo, M. I. Arriortua* (25 July), J. Ruiz, $X$. Solans (20 and 21 July).

Sweden (2): R. Norrestam, I. Olovsson.

Switzerland (2): H. B. Bürgi (25 July), G. Chapuis, J. Daly* (20 July), H. D. Flack* (21 July).

UK (5): A. M. Glazer, J. R. Helliwell, J. A. K. Howard, J. I. Langford, M. M. Woolfson.

USA (5): C. P. Brock, R. F. Bryan, W. L. Duax, J. P. Glusker, W. A. Hendrickson.

USSR (5): K. S. Aleksandrov, L. A. Aslanov* (21 July), E. G. Harutyunyan, T. I. Malinowsky, M. A. PoraiKoshits (20 and 25 July), E. V. Suvorov* (21 July), B. K. Vainshtein (20 and 25 July).

Yugoslavia (1): L. Golic*.

Present as members of the Executive Committee: M. Nardelli (President), T.-q. Tang (Vice-President), A. I. Hordvik 
(General Secretary and Treasurer), Th. Hahn (Immediate Past President), A. Authier, P. Coppens, R. Diamond, A. Kálmán, E. N. Maslen and V. I. Simonov (Ordinary Members). J. N. King was in attendance as Executive Secretary.

First Session, Friday 20 July 1990, 7.35 p.m.

(1) Introductory remarks by the President

Professor NARDELLI welcomed the delegates and observers.

\section{(2) Procedural matters}

In order to verify the list of voting delegates, the President requested the General Secretary to read this list, and asked delegates to indicate their presence when their names were called. (This procedure was repeated at the beginning of each session of the General Assembly.)

Two delegates, G. R. Desiraju (India) and R. Norrestam (Sweden), were appointed to act as tellers when votes had to be counted during the Assembly.

\section{(3) Approval of the Agenda}

The Agenda and the Appendices to the Agenda had been distributed to Secretaries of National Committees in May 1990. It was agreed that the confirmation of the date and place of the Sixteenth General Assembly (Minute 26) should be dealt with immediately after the approval of the Minutes of the Extraordinary General Assembly of 19 December 1989 (Minute 6). The Agenda were approved.

(4) Change in nature of the UK National Committee for Crystallography

The Royal Society, the Adhering Body in the UK, had made major changes in its arrangements with the International Council of Scientific Unions (ICSU) and the international scientific Unions adhering to ICSU. These entailed the dissolution of the National Committee for Crystallography and other similar committees for other scientific Unions on 31 December 1989 and their replacement by an International Relations Committee. The new arrangements were designed (1) to facilitate more direct links between the international Unions, including the $\mathrm{IUCr}$, which adhered to ICSU and the relevant sections of the scientific community in the UK; (2) to address, in a UK context, the duplication and overlaps in the remits of ICSU's scientific committees and interdisciplinary programmes; and (3) using the savings from this administrative reorganization, to enhance UK participation in the scientific work of ICSU, its committees and the international Unions, especially by younger workers. The Royal Society would continue to be the Adhering Body to the IUCr, other Unions and ICSU. The membership of the International Relations Committee included one scientist representing each of the Unions adhering to ICSU, with M. M. Woolfson representing the IUCr. However, in the IUCr Statues, Statute 3.3 requires each Adhering Body to form a National Committee for Crystallography to represent it in the Union, while Statute 3.5 requires that any major change in the nature of an Adhering Body shall be considered valid only after it has been reported to and accepted by the General Assembly.

M. M. WoOlfSON, Chairman of the UK delegation, explained that the changes made by the Royal Society were made on the grounds of economy and of efficiency. Since the formation of the British Crystallographic Association
(BCA) it had been that body, rather than the National Committee for Crystallography, which had represented the interests of the UK crystallographers. Two years ago he was both the Chairman of the National Committee and President of the BCA. He adopted the practice of sending all papers relating to the IUCr both to members of the National Committee and to members of the BCA Council. In fact, about half the people involved were members of both bodies. The British crystallographic community was well represented by the $\mathrm{BCA}$, and the $\mathrm{BCA}$ Council met twice a year. Hence, when the Royal Society proposed the action it had now taken, he could see only benefits as far as crystallography was concerned. He was still of that opinion and he believed that the requirements of the $\mathrm{IUCr}$ were well met by the new arrangement.

R. DIAMOND, an Ordinary Member of the IUCr Executive Committee and current President of the BCA, endorsed the remarks made by Professor Woolfson. He had no doubt that the level of consultation amongst British crystallographers regarding the activities of the Union was much improved as a result of the new arrangement.

The General Assembly accepted the change in nature of the UK National Committee for Crystallography.

\section{(5) Approval of the Minutes of the Fourteenth General Assembly}

The Minutes, which were contained in the published Report of the Fourteenth General Assembly and International Congress of Crystallography [Acta Cryst. (1988), A44, 567-621], were approved and two copies were signed by the President and the General Secretary, in accordance with By-Law $1 \cdot 13$. There were no matters arising from the Minutes.

(6) Approval of the Minutes of the Extraordinary General
Assembly, London, England, 19 December 1989

The Minutes, which had been submitted to the National Committees and the Commissions in May 1990, were approved and two copies were signed by the President and the General Secretary, in accordance with By-Law 1.13. There were no matters arising from the Minutes, which were published subsequently [Acta Cryst. (1990), A46, 716719].

\section{(7) Report of the Executive Committee}

The Report of the Executive Committee on the activities of the IUCr since the Fourteenth General Assembly had been submitted to the National Committees and the Commissions in May 1990, in accordance with Statute 6.8 and follows these Minutes as Annex I, Appendix A. The report was accepted without discussion.

\section{(8) Financial Report}

A Financial Report, covering the calendar years 1987 , 1988 and 1989, had been prepared by the Treasurer and had been submitted to the National Committees and the Commissions in May 1990. The Report follows these Minutes as Annex I, Appendix B.

The Treasurer reported that the financial state of the Union was healthy. Rather than discussing the details of the Report, he spoke of the general trends. He presented figures showing (1) the increase in the total assets of the Union, (2) the excess of income over expenditure for Acta Crystallographica, (3) the income and the expenditure for 
Acta Crystallographica, including estimates for 1990 and 1991 , since this was the largest financial activity of the Union, and (4) the activities of the Research and Education Fund (REF) and the Publications and Journals Development Fund (PJDF). The PJDF was necessary to support the improvements and advances in the Union's publishing activities, particularly with its journals. The REF had so far mainly been used to enable young scientists to attend scientific meetings, but there were also plans for funding Visiting Professorships to enable scientists to visit developing countries. These two funds, REF and PJDF, had been built up by transfers from other funds. However, the Executive Committee aimed to make these funds self-supporting, so that the interest earned by the balances in these funds is sufficient to pay for the activities financed by the funds.

M. M. WOOLFSON (UK) expressed concern that the introduction of new technology for the journals, which had been expected to lead to reduced manpower requirements, had in fact led to a reduction in the number of pages published because of the extra workload placed on the editorial staff. He asked for a statement regarding the future savings in costs which will result from the introduction of new technology. He recalled the large increases in prices which had resulted in 1981 from the previous attempt to introduce new technology. He was concerned to hear that the Convener of the Finance Committee and the Treasurer had somewhat different views about how the expenditure on the journals would change over the next few years.

In reply, the Treasurer explained that, at present, it cost about $£ 26$ to typeset a page of Acta Crystallographica. If we could do this from electronically submitted material, it would cost $£ 6$. Acta Crystallographica Section C currently consisted of about 2500 pages per annum, so that if half of the pages in Acta $\mathrm{C}$ could be handled in this way there would be considerable savings.

The General Assembly accepted the Financial Report with acclamation.

\section{(9) Ewald Prize}

The General Assembly applauded Professor B. K. Vainshtein, to whom the second Ewald Prize had been presented at the Opening Ceremony. Details of the Prize and the citation are given in Annex I, Appendix C.

\section{(10) Commission on Journals}

The report of the Commission on Journals had been distributed to the National Committees and the Commissions in May 1990 and is reprinted in Annex I, Appendix D. The Chairman of the Commission, C. E. BUGG, had nothing to add to the report. There were no questions and there was no discussion of future activities.

The report was accepted by the General Assembly.

\section{(11) Commission on International Tables}

The report of the Commission on International Tables had been distributed to the National Committees and the Commissions in May 1990 and is reprinted in Annex I, Appendix D. The Chairman of the Commission, A. J. C. WILSON, had nothing to add to the report but he urged delegates to attend the Open Commission Meeting. There were no questions and there was no discussion of future activities.

The report was accepted by the General Assembly.

\section{(12) Commission on Structure Reports}

The report of the Commission on Structure Reports had been distributed to the National Committees and the Commissions in May 1990 and is reprinted in Annex I, Appendix D. The Chairman of the Commission, G. FERGUSON, was not present. There were no questions and there was no discussion of future activities.

The report was accepted by the General Assembly.

\section{(13) Working Party on Crystallographic Information}

The report of the Working Party had been distributed to the National Committees and the Commissions, with the other Agenda papers, in May 1990, and is reprinted in Annex I, Appendix E.

H. FREEMAN (Australia) complained that the detailed proposal for a standard file had not been submitted to the General Assembly, as had been promised in the report. E. N. MASLEN, the Chairman of the Working Party, explained that the distribution of this material had been delayed until suitable copyright protection of the standard file had been made. Although he was not certain of the exact date of distribution it had been received by some delegates two to three weeks before the General Assembly. Furthermore, there had been a full presentation of this standard file at a session of the Congress on the afternoon prior to the present session of the General Assembly.

The President thanked Dr Maslen and the members of the Working Party for their excellent work and their important conclusions and recommendations. Their work was completed and it marked the start of a new life in the technical aspects of the publishing activities for the Union. What had emerged was that the technological developments, with their high potential for scientific publication, presented a new challenge, making this an exciting time in the Union's history. It was also obvious that many other organizations are facing similar challenges. The Union's future would be affected significantly by the success or failure of the reorganization which was now in progress.

It was unlikely that the present structure of the Union Commissions was optimal for future activities. However, given the goodwill of those affected, reorganization of Commission structure was less urgent than the immediate technical challenges, and was envisaged as occurring in the next triennium.

The General Assembly accepted the report of the Working Party.

\section{(14) Reports of the non-publishing Commissions}

The reports of the Commissions on their activities since the Fourteenth General Assembly had been distributed to the National Committees and the Commissions in May 1990. The reports are reprinted in Annex I, Appendix D. No report was received on the activities of the ad interim Commission on Modulated Structures, Polytypes and Quasi-crystals (see also Minute 15). The reports were taken as read, but the Chairman of each Commission, or his alternate, was invited to say a few words about any further developments and to answer any questions. However, no Chairman wished to add anything and there were no questions.

The General Assembly accepted all the reports which had been received on the activities of the non-publishing Commissions. 
(15) Ad interim Commission on Modulated Structures, Polytypes and Quasi-crystals

This Commission had been established, ad interim, by the General Assembly at Perth in 1987. Although no written report had been received on the activities of this Commission, the Executive Committee had met with its Chairman, D. Gratias, immediately prior to the General Assembly.

The Immediate Past President explained that the Executive Committee was not proposing the confirmation of the Commission, but rather its dissolution. However, the Executive Committee considered the field to be a very important one, which should be covered within the Union. Discussions would take place in the next few days and the Executive Committee hoped to present a firm proposal to the General Assembly at a subsequent session.

Since there was no proposal to confirm the establishment of the Commission, no voting was required.

\section{(16) Proposal to establish a Commission on Synchrotron} Radiation

The proposal to establish the Commission, and its proposed terms of reference, had been circulated with the Agenda papers.

H. C. FREEMAN (Australia) reminded delegates that most countries represented in the Union did not have synchrotron-radiation facilities. Whilst the Australian delegation supported the establishment of the Commission, it proposed that, at all times, the membership should include one member from a country which had users of synchrotron radiation but which did not have its own synchrotronradiation facilities.

In reply, J. R. Helliwell (UK), the Chairman of the ad interim Commission, stated that the Commission membership had been made with the intention of covering the widest range of facilities. He, and all members of the Commission, were cognizant of the needs of users who did not have facilities of their own, but it was important for the Commission membership to reflect the various facilities currently available. There were more facilities than could be represented within the Commission membership, and he hoped that this deficiency, and representation such as proposed by Professor Freeman, could be covered by the use of Consultants. Delegates were also reminded that point (v) of the proposed functions of the Commission was specifically directed to meeting the needs raised by Professor Freeman. The President reminded delegates that, at this stage, the delegates were being asked only to decide whether they wished to establish the Commission. If they decided to establish the Commission, then the membership would be considered at a later stage.

The General Assembly formally established the Commission with the following terms of reference:

(i) Crystallography of small molecules and large molecules in the areas of very high resolution, large unit cells, microcrystals, reduced radiation damage, kinetic crystallography and multi-wavelength anomalous-dispersion phasing.

(ii) Fibre diffraction and small-angle scattering including time-resolved studies.

(iii) X-ray topography.

(iv) EXAFS (extended X-ray absorption fine structure).

(v) Diffuse scattering. (vi) X-ray optics and detectors of particular relevance to the utilization of the unique properties of synchrotron radiation.

(vii) Magnetic scattering.

(viii) High pressure diffraction.

The Commission will serve several functions as follows:

(i) To assist in the organization of relevant sessions at IUCr Congresses and other meetings that will catalyse developments and innovations in the subject.

(ii) To catalogue information on the available synchrotron-radiation sources and the instrumentation relevant to the above topics. This information will be made freely available and so improve the future planning, use and effectiveness of the global resources available for the community of crystallographers and diffractionists represented by the IUCr.

(iii) To provide a forum for comparing and contrasting the policies of the various centralized synchrotron facilities.

(iv) To facilitate scientific and technical studies aimed at improving standards of sources, equipment and procedures.

(v) To try to provide a mechanism whereby potential users of synchrotron radiation from anywhere in the world can be directed to the appropriate facility and helped with gaining access there.

The Commission will be distinct from, and complementary to, the other Commissions of the IUCr. There will be parallel interests with the Commission on Neutron Diffraction, which deals with centralized neutron facilities, and in instrumentation with the Commission on Crystallographic Apparatus. There will also be cooperation with the Commission on Crystallographic Teaching in the preparation of a booklet on synchrotron radiation.

(17) Determination of the number of elected members of each Commission

In accordance with Statute $5 \cdot 10(d)$, the Assembly had to determine the number of persons to be elected on the Commissions until the Sixteenth General Assembly; these numbers did not include Chairmen, Co-editors or ex officio members.

At its meeting in Perth in 1987, the Executive Committee agreed to propose that, for the period 1990-1993, the number of elected members be reduced for some Commissions, as set out below. The use of consultants was recommended instead of so many elected members.

Commission on Charge, Spin and

Momentum Densities

Commission on Electron Diffraction

From 11 to 9

Commission on Small Molecules

From 10 to 8

From 10 to 9

In addition, the Executive Committee now proposed that the membership of (1) the Commission on Crystallographic Data be increased from 8 to 9 members, and (2) the Commission on Powder Diffraction be increased from 6 to 9 members.

The numbers of elected members approved by the General Assembly (Chairmen not included) are set out below:

1. Commission on Journals

2. Commission on Structure Reports

3. Commission on International Tables

4. Commission on Biological Macromolecules 
5. Commission on Charge, Spin and Momentum Densities

6. Commission on Crystal Growth and Characterization of Materials

7. Commission on Crystallographic Apparatus

8. Commission on Crystallographic Computing

9. Commission on Crystallographic Data

10. Commission on Crystallographic Nomenclature

11. Commission on Crystallographic Teaching

12. Commission on Electron Diffraction

13. Commission on Neutron Diffraction

14. Commission on Powder Diffraction

15. Commission on Small Molecules

16. Commission on Synchrotron Radiation

The President then adjourned the session at 9.45 p.m.

Second Session, Saturday 21 July 1990, 7.35 p.m.

(18) Reports of representatives on Scientific and Regional Associates

In accordance with Statute 8.5 the reports of the representatives on Scientific and Regional Associates had been circulated with the Agenda papers in May 1990. These reports, with subsequent corrections, are reprinted as Annex I, Appendix F. The reports were accepted. The General Assembly welcomed the newly elected President of the Asian Crystallographic Association, N. Kasai (Japan).

(19) Application by the American Crystallographic Association ( $A C A$ ) to become a Regional Associate

The President read out a statement by the Executive Committee, which had considered the application immediately prior to the General Assembly. The Executive Committee unanimously recommended acceptance of the application. The statement noted that the Union currently had two Regional Associates, the European Crystallographic Committee and the Asian Crystallographic Association, representing the crystallographic communities in those areas. The Executive Committee welcomed the application of the ACA, representing the United States and Canada, to become the third Regional Associate, of a size roughly equal to that of the other two Associates. The application had the full support of the US and Canadian National Committees for Crystallography. The Executive Committee believed that acceptance of the ACA as a Regional Associate would strengthen the Union and ensure the participation of the North American community in the activities of the Union.

After a brief discussion the Assembly accepted the ACA as a Regional Associate of the Union.

(20) Reports of representatives on bodies not belonging to the Union

In accordance with Statute 8.5 the reports of these representatives had been circulated with the Agenda papers. All these reports are printed as Annex I, Appendix $G$ to these Minutes. None of the representatives had anything to add to these reports and there were no questions. All the reports were accepted.

(21) Sponsorship of meetings: Sub-committee on the Union Calendar

Since this is a sub-committee of the Executive Committee, the Assembly is not formally required to approve its report, but it did in fact do so. The report is printed as Annex I, Appendix $\mathrm{H}$ to these Minutes.

\section{(22) IUCr/Oxford University Press Book Series}

The report on this Book Series was accepted by the Assembly without comment. It is printed as Annex I, Appendix I.

(23) Determination of the general policy and the timetable for the period to the Sixteenth General Assembly

It was noted that several meetings to be held in this period had already requested Union sponsorship and financial support. The delegates made no further observations or comments.

(24) Preliminary consideration of activities for the period 1993-1996

There were no comments on this item.

(25) Budget estimates for the period to the Sixteenth General Assembly: determination of the unit contribution

These budget estimates had been distributed with the Agenda papers and are printed as Annex I, Appendix $J$ to these Minutes.

In answer to questions about the level of financial support for Congresses and their satellite meetings, the Executive Secretary referred delegates to the information given in the Finance Report (Appendix B), under the General Fund and the Research and Education Fund for the previous Congress. M. Hospital (France) reported on the financial support which the present Congress organizers had been able to give, including the funds donated by the Union.

The General Assembly accepted the budget estimates and approved the recommendation of the Executive Committee to continue the unit contribution unchanged, as Sw Fr 890 , for the years 1991, 1992 and 1993.

\section{(26) Confirmation of the date and place of the Sixteenth General Assembly}

M.C. SHAO (China) confirmed the invitation by the Chinese National Committee for Crystallography and the China Association for Science and Technology (CAST) to hold this General Assembly and Congress in Beijing. He reported that great progress had been made since the Extraordinary General Assembly in December 1989. CAST, as a National Member of ICSU, has always firmly observed the ICSU principles of the free circulation of scientists attending international scientific meetings. He confirmed that it was proposed to hold the General Assembly and Congress at the site of the Beijing Asian Games Athletes Village (BAGAV), which was situated about $9 \mathrm{~km}$ north of the Forbidden City and $20 \mathrm{~km}$ to the west of the international airport. There would be complete modern conference facilities which would fully meet the requirements of an IUCr General Assembly and Congress, including two main conference halls each capable of accommodating more than 1500 people, several rooms for microsymposia with capacities ranging from 50 to 600 people and exhibition halls with a total area of 5000 square metres. All the activities of the General Assembly and Congress could be held within the same building. In the vicinity of the BAGAV there is a range of accommodation up to luxury hotel standard, with prices ranging from US $\$ 20$ to US $\$ 140$ per person. Professor Shao assured delegates that the registration fee would be similar to that for the Bordeaux Congress, 
except for any adjustment as a result of inflation. Initially, in 1987, it had been proposed that the Congress be held at the end of August, but it was now proposed to hold it at the beginning of September, since in August the humidity and the temperature were perhaps too high for comfort. He concluded by showing a short film.

Several delegates requested that the Congress be held at the end of August, which Professor Shao said could be done.

The invitation, which had been preliminarily accepted in 1987 and at the Extraordinary General Assembly in December 1989, was formally accepted. The General Assembly requested that the dates should be changed back to the end of August 1993.

(27) Preliminary consideration of the date and place of the Seventeenth General Assembly

In accordance with By-Law 1.3, the General Assembly could give preliminary consideration to the place of the next but one General Assembly, namely the Seventeenth General Assembly to be held in 1996. The President announced that only one invitation had been received, from the US National Committee for Crystallography, on behalf of the National Academy of Sciences of the United States, and in collaboration with the American Crystallographic Association. He noted that, at present, the invitation did not specify a location. He invited the US delegation to give further information about the invitation and to answer questions.

R. F. BRYAN (USA) presented the formal invitation to the General Assembly and identified several possible locations. In answer to questions, he assured delegates that everything possible would be done to ensure that all intending participants at the Congress would receive visas but he was not in a position to give an absolute guarantee that everyone would receive a visa, since the US Government reserved the right to refuse entry to anyone. The US National Committee would receive full support and assistance in this matter from the National Academy of Sciences, which is the National Member for the US to ICSU.

After a full discussion the General Assembly gave preliminary acceptance to the invitation to hold the Seventeenth General Assembly in 1996 in the USA.

The President adjourned the session at 9.10 p.m.

\section{Third Session, Wednesday 25 July 1990, 7.30 p.m.}

(28) Confirmation of the appointments of the Editors of the publications of the Union

In accordance with Statute $7 \cdot 1$, the initial appointments and the reappointments of the Editors of the publications of the Union were made by the Executive Committee and were subject to confirmation by the General Assembly.

In addition to the appointments and reappointments notified to delegates in the Agenda papers, the Executive Committee had appointed the following Editors for International Tables. Professor A. Authier for Volume D (Physical Properties of Crystals) and Dr V. Kopsky and Dr D. B. Litvin for Volume E (Subperiodic Symmetry Groups).

The Assembly unanimously confirmed the following appointments and reappointments for the period of three years:

Editor of Acta Crystallographica: C. E. Bugg (USA)

Editor of Journal of Applied Crystallography: A. M. Glazer (UK)
Editor of Structure Reports: G. Ferguson (Canada)

Editor of International Tables and Editor of Volume C: A. J. C. Wilson (UK)

Editor of Volume A: Th. Hahn (Germany)

Editor of Volume B: U. Shmueli (Israel)

Editor of Volume D: A. Authier (France)

Editors of Volume E: V. Kopsky (Czechoslovakia) and D. B. Litvin (USA)

\section{(29) Election of Chairmen and members of Commissions}

The nominations made by the Executive Committee for the Chairmen and elected members of Commissions, after consultation with the Commissions through their Chairmen, had been notified to delegates. This list of nominations included ex officio members of the non-publishing Commissions, for information.

Since no other nominations had been made by the delegates, the persons nominated by the Executive Committee were considered elected.

The current full memberships of all the Commissions, including the ex officio members, together with the addresses of the Chairmen, are given in Annex III.

(30) Election of representatives on bodies not belonging to the Union and on Regional and Scientific Associates

The nominations made by the Executive Committee for those representatives to be elected by the General Assembly had been notified to delegates. As no other nominations were made, these persons were considered elected.

The names and addresses of the representatives of the Union, including those appointed ex officio, are given in Annex III.

\section{(31) Election of Officers of the Union}

The nominations made by the Executive Committee for Officers of the Union had been included in the Agenda papers distributed in May 1990. A. Authier was nominated for President, A. Kálmán for Vice-President, A. I. Hordvik for General Secretary and Treasurer, D. M. Kheiker (USSR) for Ordinary Member for the remaining three-year period of the vacancy created by the death of S. A. Semiletov (USSR) on 27 July 1988. J. Harada (Japan), K. Huml (Czechoslovakia) and H. Schenk (Netherlands) were nominated for Ordinary Members for the three vacancies for the normal six-year term. No other nominations were made by the delegates for the offices of President, Vice-President or General Secretary and Treasurer. However, there were nominations by the delegates for the offices of Ordinary Members. Y. T. Struchkov (USSR) was nominated for the three-year period. R. Chidambaram (India), P. W. Codding (Canada) and G. S. D. King (Belgium) were nominated for the normal six-year term. The President did not allow any discussion before the election but said that he would invite comments afterwards. Elections for these four offices of Ordinary Members were held by secret ballot. The following nominees were elected:

President:

A. Authier (France)

Vice-President:

A. Kálmán (Hungary)

General Secretary and Treasurer:

A. I. Hordvik (Norway)

Ordinary member (three years):

Y. Struchkov (USSR) 
Ordinary members (six years):

R. Chidambaram (India)

P. W. Codding (Canada)

J. Harada (Japan).

Following these elections, the President invited comments.

M. M. WoOLFSON (UK) considered that a pattern seemed to have been established for having contested elections. However, he hoped that this would not get out of hand, with a large number of candidates being nominated for a small number of places, because he thought that, under such circumstances, the possibility of achieving a good balance between subjects within crystallography and geographical distribution would be much reduced. He suggested that delegates might perhaps only make additional nominations to those presented by the Executive Committee if they feel that there was a good reason to do so. Secondly, he suggested that, if there were to be contested elections, then it was important that the delegates received brief biographical sketches of the candidates before the voting took place. Thirdly, he noted that, for the whole of the Union's existence over a period of over 40 years, there had always been someone from the UK, the USA and the USSR on the Executive Committee. He hoped that, someday, he would see an Executive Committee which did not contain a member from each of these countries.

In the absence of any other comments, the President suggested to the delegates that they could write to the new President after the General Assembly if they wished to express an opinion on the electoral procedure.

The newly elected President expressed his gratitude to the delegates for the high honour they had bestowed on him by electing him to join the distinguished line of Presidents of the Union. He was fully aware of the great responsibility which came with that office. With regard to the elections which had just been held for Ordinary Members of the Executive Committee, he considered all those who had been nominated to be excellent candidates. The fact that there could be so many excellent candidates was a healthy indication of the strength of the Union. He completely endorsed the comments of Professor Woolfson, who had said exactly what he intended to say in his Presidential Speech, including the suggestion for biographical informa- tion to be provided. He believed that there should be an opportunity for choice and he would be making suggestions to the new Executive Committee, with the objective that the Executive Committee should, in future, make more nominations than there are vacancies.

There being no further business, and therefore no need for the final session of the General Assembly which had been scheduled for 28 July, the President declared the Fifteenth General Assembly closed.

\section{Closing Ceremony, Saturday 28 July 1990}

M. Hospital, Chairman of the Congress Organizing Committee, spoke about the work of his committee in securing the success of the Congress. He was happy to see that the various difficulties had all been successfully overcome, particularly those caused by the extremely hot weather. He presented all the members of his committee, thanking them for all their hard work.

M. NARDELLI, the retiring President, introduced the newly elected President and the other new members of the Executive Committee. He expressed his satisfaction at the scientific success of the Congress, which had considered the most advanced aspects of crystallography, showing the importance of this discipline in many fields of modern science. On behalf of all the participants, he thanked the Chairmen of the Organizing Committee and the Programme Committee for their work, which had been so essential for the success of the Congress. He also thanked the members of the Executive Committee, the Finance Committee, the Commissions of the Union and the delegates at the General Assembly for their help and cooperation. He concluded by wishing every success to the Union, its new President and new Executive Committee.

M. MORETON MOORE (UK) then presented the prize for the best poster. NATACHA KLOKOVA (USSR) spoke on behalf of the young scientists.

In his concluding remarks A. AUTHIER, the new President, said that he looked forward to meeting everyone in Beijing in 1993. He then declared the Fifteenth General Assembly and Congress officially closed. 


\section{ANNEX I}

\section{Appendices to the Agenda of the Fifteenth General Assembly}

\section{Appendix A: Report of the Executive Committee}

Executive Committee and Finance Committee meetings

The Executive Committee met in Perth in August 1987 before and during the General Assembly, in Vienna, Austria, in September 1988 at the time of ECM-11, and in Rowton, near Chester, England, in July 1989. It also held a special meeting in London on 19 December 1989 prior to the Extraordinary General Assembly on that day. The Finance Committee met twice a year, the second time being prior to the Executive Committee meeting, to prepare its advice and recommendations on finances, establishment and staff matters.

The most important items of business dealt with by the Executive Committee during the triennium at these meetings and in postal ballots between meetings were:

(1) Editorial policy, pricing policy and subscription rates, approval of appointments of Co-editors and other matters concerning the IUCr journals.

(2) Appointment of new staff in the IUCr office in Chester.

(3) Upgrading of office technology in the IUCr office in Chester and expansion of this office.

(4) Future of Structure Reports and their cooperation with databases, including relations between the $\mathrm{IUCr}$ and the Cambridge Crystallographic Data Centre.

(5) Establishment of a Working Party on Crystallographic Information, to assess the need for a Commission on Crystallographic Information, and consideration of that Working Party's reports.

(6) Development of electronically assisted publication.

(7) Publication and pricing of new editions of current volumes and approval of section authors for new volumes of International Tables.

(8) Approval of publications, jointly with the Oxford University Press, in the IUCr/OUP Book Series.

(9) World Directory of Crystallographers.

(10) Historical Atlas of Crystallography.

(11) Approval of the audited accounts for the previous year.

(12) The General Fund estimates and the level of the unit contribution.

(13) Investment policy.

(14) Funding and uses of the Publications and Journals Development Fund and the Research and Education Fund.

(15) Consolidation of the Ewald Fund and appointment of the Selection Committee for the second Ewald Prize.

(16) Sponsorship of meetings and and possible financial support for meetings.

(17) Young scientists' support to meetings.

(18) Free circulation of scientists.

(19) Approval of the membership of the Programme Committee for the Bordeaux Congress.

(20) Discussion of the arrangements for the Bordeaux General Assembly and Congress with the Programme Committee.
(21) Level of financial support for the Bordeaux Congress and its satellite meetings, including a separate fund for young scientists.

(22) Review of the activities of the Commissions.

(23) Establishment of an ad interim Commission on Synchrotron Radiation.

(24) Review of IUCr representation on the Scientific and Regional Associates and on other bodies.

(25) Nominations for Officers of the IUCr and for Chairmen and members of Commissions, and proposals from the National Committees for these positions.

\section{Publications}

The subscription prices (in Danish kroner) of Acta Crystallographica were increased by $10 \%$ for 1990 , having been kept virtually constant since 1983, but it was not found necessary to increase the subscription prices of the Journal of Applied Crystallography.

The total annual number of pages published in 1987, 1988 and 1989 were:

$\begin{array}{lrrr} & 1987 & 1988 & 1989 \\ \text { Acta Cryst. Section A } & 840 & 1104 & 920 \\ \text { Acta Cryst. Section B } & 584 & 680 & 600 \\ \text { Acta Cryst. Section C } & 2472 & 2240 & 2030 \\ \text { J. Appl. Cryst. } & 538 & 996 & 642 \\ \text { Total } & 4434 & 5020 & 4192\end{array}$

In addition, in 1987 Acta Cryst. Section A included a Supplement of 360 pages of abstracts communicated to the Perth Congress. The December 1988 issue of J. Appl. Cryst. included 43 papers ( 305 pages) contributed to the International Conference on Small-Angle Scattering, Argonne, Illinois, USA, 26-29 October 1987. The low number of pages published in Acta Cryst. Section C in 1989 resulted from backlogs of these structural papers, both in the editorial office in Chester and at the typesetters. The appointment of more staff in the editorial office and the use of new equipment at the typesetters should reduce this backlog in 1990. The total number of subscriptions has stayed almost constant during the triennium. More details are given in the Report of the Commission on Journals.

The introduction of a Fast Communications section in Acta Cryst. Section A for quickly reporting important results in all areas of crystallography, the increased frequency of publication (monthly) of this Section, and the active encouragement of Lead Articles in Acta Cryst. and J. Appl. Cryst. are all steps introduced by the Commission on Journals and encouraged by the Executive Committee to improve the attractiveness of these journals.

Full details on the publication of volumes of Structure Reports and of International Tables for Crystallography are given in the Reports of these Commissions.

The Eighth Edition of the World Directory of Crystallographers, edited by E. N. Maslen, will be published during 1990.

The establishment, jointly with Oxford University Press, of the IUCr/OUP Book Series has been very successful. Details are given in the relevant Appendix to the Agenda. 


\section{Sponsorship of meetings}

The Executive Committee has a Sub-committee on the Union Calendar to consider and to advise the Executive Committee on requests for IUCr sponsorship and financial support of meetings. The Chairman of the Sub-committee has been E. N. Maslen in this triennium. Because of its improved financial status, the IUCr could be more generous than earlier in providing financial support to help young scientists attend meetings. A list of IUCr-sponsored meetings is given in the Report of the Calendar Sub-committee.

Applications for sponsorship and financial support are normally only considered if they are submitted at least six months in advance of the date of the meeting. Requests from satellite meetings must be submitted, and possible financial support requested, through the organizing committee of the main meeting.

The IUCr continues to support and uphold ICSU's policy of non-discrimination and adheres to their decisions and procedures concerning free circulation of scientists. Organizers of any meetings seeking IUCr sponsorship or support must assure the Calendar Sub-committee that the authorities of the country in which the meeting is to take place guarantee free entrance of bona fide scientists from all countries.

\section{Commissions of the $\mathrm{IUCr}$}

Each Commission Chariman is required to provide a written triennial report to the General Assembly. These reports are included as Appendices to the Agenda. Financial assistance has again been offered to the Commission Chairmen, to enable them to attend the General Assembly for the presentation and discussion of their reports and to meet the Executive Committee prior to the General Assembly.

In July 1989 the Executive Committee decided to establish a Commission on Synchrotron Radiation, ad interim until the Bordeaux General Assembly. Professor J. R. Helliwell kindly accepted the Executive Committee's invitation to chair this Commission and to draft its terms of reference.

\section{Regional Associates, Scientific Associates and other bodies}

The reports of the representatives on these bodies are given as separate Appendices to the Agenda.

\section{IUCr staff}

There have been some staff changes during the triennium. The present members of staff in the IUCr office in Chester are: Dr J. N. King (Executive Secretary), Mrs A. Cawley (Administrative Assistant to the Executive Secretary), Mr M. H. Dacombe (Technical Editor), Miss S. E. Lowe and Mr P. R. Strickland (Assistant Technical Editors), Mr B. McMahon (Editorial Assistant and Computer Supervisor), Mr S. R. Anderson, Miss A. S. Berry, Miss M. J. Godden (who leaves in June 1990) and Dr M. Hurst (Editorial Assistants), Ms L. Allsop (Secretary) and Mrs C. Cash (part-time Secretary).

Additional editorial staft will need to be appointed in 1990 to handle the increased workload resulting from (1) the transfer of the consistency and duplication checking from the journals' Co-editors to the Chester office, (2) the increased number of manuscripts being submitted for publication in Acta Cryst. and J. Appl. Cryst., (3) the introduction of the facility for the submission of manuscripts in electronic form, and (4) the archiving of structural data in connection with (3) above. The above expansion in staff has necessitated the IUCr acquiring more office accommodation in Abbey Square.

\section{Acknowledgements}

On behalf of the IUCr, the Executive Committee wishes to express its deep gratitude to the Association Française de Cristallographie and the Académie des Sciences for the invitation to hold the Fifteenth General Assembly and International Congress of Crystallography in Bordeaux. It particularly wishes to thank the Chairman of the Programme Committee, Professor A. Authier, and the Chairman of the Organizing Committee, Dr M. Hospital.

The continuing support shown by Unesco in the form of its annual subvention received by the $\mathrm{IUCr}$ through ICSU, and the support of ICSU itself, is gratefully acknowledged.

Finally, the Executive Committee wishes to thank all crystallographers who have assisted in the work of the JUCr in so many ways. This cooperation between crystallographers of different nationalities constitutes a most valuable aspect of the IUCr's activities.

\section{Appendix B: Financial Report}

\section{The fund's structure}

The accounts of the IUCr for the calendar years 1987 and 1988 have already been published [Acta Cryst. (1988), A44, 741-764 and (1989), A45, 739-764]. The accounts for 1989 have been audited and will be published in due course in Acta Crystallographica Section A. The accounts for the three years 1987, 1988 and 1989 are summarized in Tables 1-14. All amounts are expressed in Swiss Francs. The notations used in this report for the various currencies of the IUCr's activities are CHF $=$ Swiss Franc, GBP $=$ Pound Sterling, USD = US Dollar, NLG = Netherlands Guilder, DKK = Danish Krone.

\section{General financial development}

Table 1 shows a comparison of the fund accounts at the beginning and the end of the triennium. No new funds were established in this period. The total assets of the IUCr have increased by CHF 1375269 , or $36 \%$, over the triennium. Of this amount, CHF 230406 , corresponding to one-sixth of the increase, is due to fluctuations in exchange rates.

Table 2 shows the distribution of the assets. The amount of CHF 342577 for debtors at 31 December 1989 is normal. It includes, in part, the IUCr's funding of the XV General Assembly and Congress paid in advance, but the largest part relates to amounts due at that date in respect of the publishing operations during 1989, from Munksgaard for the journals and from Kluwer for International Tables, Structure Reports and other publications. These amounts, due in early 1990, and the great majority of the other amounts under debtors and creditors, have since been settled.

The nature of the assets was changed to some degree during the triennium, mainly by reducing the amounts held with the banks in deposit and savings accounts and by increasing the holdings in investments. The total investments at 31 December 1989 are CHF 4477612 , as shown in Table 2, of which $16.85 \%$ is held by Rothschild Asset Management, $25.0 \%$ by Merrill Lynch, and $58.15 \%$ by Foreign \& Colonial. The IUCr bank accounts and shortterm deposits are held with the Union Bank of Switzerland, 
Table 1. Balance Sheet, Fund Accounts (Swiss Francs)

\begin{tabular}{|c|c|c|c|}
\hline & 31 December 1986 & $\begin{array}{l}\text { Fluctuations } \\
\text { in rates } \\
\text { of exchange }\end{array}$ & 31 December 1989 \\
\hline General Fund & 801077 & 55665 & 1170342 \\
\hline President's Fund & 15573 & 705 & 16686 \\
\hline Acta Crystallographica & 1577901 & 94623 & 2090433 \\
\hline Journal of Applied Crystallography & 329591 & 18400 & 442674 \\
\hline Structure Reports & 110460 & 3551 & 134260 \\
\hline International Tables & 176461 & 9515 & 176773 \\
\hline Book Fund & 11440 & 632 & 11989 \\
\hline Molecular Structures and Dimensions & 5861 & 259 & 6120 \\
\hline Publications and Journals Development Fund & 366651 & 21584 & 543020 \\
\hline Research and Education Fund & 292000 & 14905 & 372377 \\
\hline Ewald Fund & 120884 & 10567 & 218494 \\
\hline TOTAL ACCUMULATED BaLANCE & 3807899 & 230406 & 5183168 \\
\hline
\end{tabular}

the National Westminster Bank, the AmsterdamRotterdam Bank and Merrill Lynch, involving the currencies CHF, GBP, NLG and USD.

As an association incorporated in Switzerland, the IUCr is exempt from Swiss Federal and Geneva Cantonal Tax. Under the terms of the United Kingdom/Switzerland Double Taxation Agreement dated 8 December 1977, investment income arising within the UK under present circumstances is not subject to United Kingdom Tax. Investment income received from other countries with which Switzerland has a Double Taxation Agreement is also exempt from tax. In October 1985 a recognition of tax-exempt status in the USA was received from the Internal Revenue Service, Department of the US Treasury.

\section{General Fund}

Table 3 shows the accounts for the General Fund (GF) and Table 4 compares these accounts for the triennium with the budget approved by the Perth General Assembly. This fund carries the income and expenditure related to the IUCr's administration and its regular scientific activities other than publications. The income has two main sources, the subscriptions from Adhering Bodies and the interest income from investments and bank accounts. The subscriptions from Adhering Bodies are based on the unit contribution, which has been CHF 890 for all three years. The total number of membership units was 148 for 1987 and 150 for 1988 and 1989, while the budget was based on 147 units for each year. The yield from investments exceeds the budgeted amount by CHF 233035 . This positive difference makes it possible for the IUCr to expand its scientific activities somewhat faster than planned.

The amount charged to the journals is calculated as $30 \%$ of the general administration costs of the IUCr, including the work of the Executive Secretary and his office and of the General Secretary and Treasure. The Executive Committee met annually, while the Finance Committee held two meetings each year. The cost of these meetings vary, as seen from Table 3, depending on the location and the circumstances. In Table 4 they are included in the expenses of administrative meetings, together with the costs of the report of the Hamburg General Assembly and Congress in 1984, the Extraordinary General Assembly in December 1989, the logo competition, and the IUCr representatives on other bodies. The expenses of scientific meetings in

Table 2. Balance Sheet, Assets (Swiss Francs)

Table 4 include the travel grants for the Perth Congress in 1987, the cost of the meeting in 1989 of the Programme Committee for the Bordeaux Congress, the expenses of the non-publishing Commissions and the Working Party on Crystallographic Information and financial support to meetings and schools. The financial support for young scientists attending meetings and schools is charged to the Research and Education Fund, see Table 13.

During the triennium CHF 102000 was transferred to the Ewald Fund.

\section{President's Fund}

Table 5 gives the account for the President's Fund. It is intended for use in emergencies and under special or 
Table 3. General Fund (Swiss Francs)

INCOME

Subscriptions from Adhering Bodies

Yield from investments and bank accounts

Grants from Unesco to ICSU and from ICSU

Grant from ICSU COSTED

Amount charged to:

Acta Crystallographica

Journal of Applied Crystallography

Molecular Structures and Dimensions

EXPENDITURE

Administration

Subscriptions to ICSU/ICSU bodies

Executive Committee

Finance Committee

XIII General Assembly and Congress:

Publication of report

XIV General Assembly and Congress:

Travel grants

Travel grants to Commissions

Executive Committee

Finance Committee

Extraordinary General Assembly

XV General Assembly and Congress:

Programme Committee

IUCr representatives on other bodies

Working Party on Crystallographic Information

Expenses of Commissions

Sponsorship of meetings

Logo Competition

Transfers to other Funds:

Publication and Journals

Development Fund

Research and Education Fund

Ewald Fund

EXCESS OF INCOME OVER EXPENDITURE

Fluctuations in Rates of Exchange

ACCUMUlated BALANCE AT THE END OF THE YEAR
1987

1988

1989
131720

188503

8814

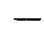

41164

13721

735

-182953

182953

4238

$9 \overline{753}$

7137

59655

22088

42749

7102

-

$3 \overline{658}$

851

16642

-

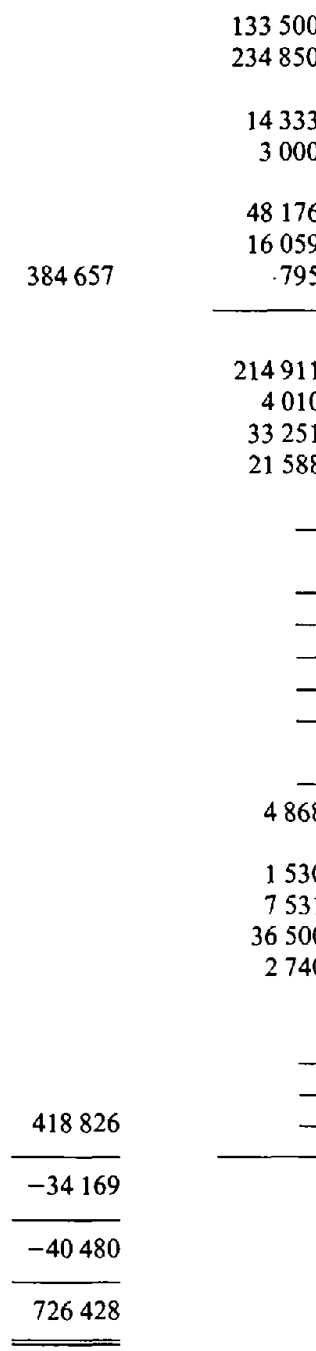

133500

389682

16428

44682

14894

450713

755

599941

199340

4835

30360

15313

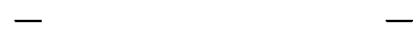

-

-

$-$

-

23306

11114

4873

7438

14056

6500

-

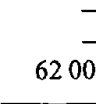

$\begin{array}{r}326929 \\ \hline 123784 \\ \hline+50393 \\ \hline 900605 \\ \hline\end{array}$
375956

223985

$+45752$

1170342

Table 4. General Fund. Comparison of budget and accounts for the years 1987-1989 inclusive (Swiss Francs)

INCOME

Budget

Accounts

Difference

Subscriptions from Adhering Bodies

Yield from investments and bank accounts

Grants from Unesco, ICSU and COSTED

392490

580000

EXPENDITURE

Administration (net)

Subscriptions to ICSU/ICSU bodies

Administrative meetings

Scientific meetings

Transfers to other fund accounts

FAVOURABLE VARIANT FROM BUDGET

ESTIMATED PROFIT

EXCESS OF INCOME OVER EXPENDITURE

\section{0}

16500

206000

278000

130000
$60000 \quad 1032490$
1032490

813035

42575

13083

214954

194470

1031600

$\begin{array}{r}+6230 \\ +233035 \\ 1254330 \quad-17425 \\ \hline\end{array}$

$+15123$

$-3417$

$+8954$

$-83530$

940730

$-28000$
$+221840$

$-90870$ 
Table 5. President's Fund (Swiss Francs)

\begin{tabular}{|c|c|c|c|}
\hline & 1987 & 1988 & 1989 \\
\hline $\begin{array}{l}\text { INCOME } \\
\text { Donations }\end{array}$ & 408 & - & 一 \\
\hline EXPENDITURE & & & \\
\hline Grants & - & - & 一 \\
\hline $\begin{array}{l}\text { EXCESS OF INCOME } \\
\text { OVER EXPENDITURE }\end{array}$ & 408 & nil & nil \\
\hline $\begin{array}{l}\text { FLUCTUATIONS IN } \\
\text { RATES OF EXCHANGE }\end{array}$ & -844 & +897 & +652 \\
\hline $\begin{array}{l}\text { ACCUMULATED BALANCE } \\
\text { AT THE END OF THE YEAR }\end{array}$ & 15137 & 16034 & 16686 \\
\hline
\end{tabular}

difficult circumstances, to help crystallographers to take part in the activities of the IUCr.

\section{The Journals Funds}

Tables 6 and 7 give the accounts for Acta Crystallographica (AC) and the Journal of Applied Crystallography (JAC). One notes from the numbers given there that the profit for both journals has stayed rather constant during the triennium. The Finance Committee (FC) and the Executive Committee (EC) have monitored the financial development for both journals very closely and, according to the predicted number of printed pages for $\mathrm{AC}$ in 1989, considered that the journal would operate at a loss in 1990. The EC therefore decided to increase the AC subscription rates by $10 \%$ for 1990 . Subscription rates had not been increased since 1983. Table 7 shows that AC came out on the positive side also in 1989. This however, should be seen in relation to the fact that the number of pages for the journal were considerably less than predicted. The final numbers of pages, including unnumbered pages, for Sections A, B and C were 924,600 and 2064 , respectively, against the predicted numbers 960,672 and 2496 .

There are temporary backlogs of manuscripts in Chester and papers at the printers, both backlogs resulting from extra work connected with the introduction of improved technologies, but there are good reasons to believe that the number of printed papers for $\mathrm{AC}$ will be back to normal in 1990. In fact, a small increase is indicated by the manuscript flow.

There was a small, although smaller than expected, decrease in the number of subscriptions, about $2 \%$, for both journals during the triennium. For further details see the Triennial Report by the Chairmen of the Commission on Journals.

\section{Structure Reports}

The Structure Reports accounts are shown in Table 8. The printing and binding costs, as well as the major part

Table 6. Acta Crystallographica (Swiss Francs)

INCOME

Subscriptions

Sale of back numbers and single copies

Airfreight charges to subscribers

Sale of microfiche

Profit on reprints

Royalties, copyright fees

Less Publisher's commission

Yield from advertisements

EXPENDITURE

Printing and binding

Distribution and postage

Airfreight costs

Loss on reprints

Annual Index

5-Year Index

Congress Supplement

Microfiching back volumes

Editorial expenses

Administration expenses

Transfers to other Funds:

Publications and Journais

Development Fund

Research and Education Fund

EXCESS OF INCOME OVER EXPENDITURE

FLUCTUATIONS IN RATES OF EXCHANGE

ACCUMULATED BALANCE AT THE END OF THE YEAR

1987

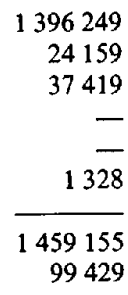

1359726

379

1360105

479154

67625

19100

18414

17261

17813

$351 \overline{403}$

41164

120000

80000

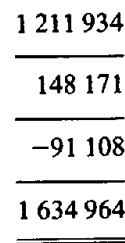

1988

1989

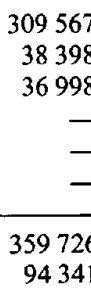

1290622

104877

$\frac{3500}{1294122}$

473815

96150

20020

11538

15165

24843

364586

48176

(1940

462305

427257

60000

60000

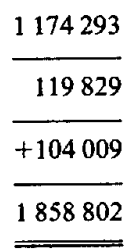

98801

38825

$15 \overline{338}$

51735

921

44682

1367631

2142

1369773

40000

40000

1219864

149909

$+81722$

2090433 
Table 7. Journal of Applied Crystallography (Swiss Francs)

INCOME

Subscriptions

Sale of back numbers and single copies

Airfreight charges to subscribers

Sale of microfiche

Royalties, copyright fees

Less Publisher's commission

Yield from advertisements

Contribution towards cost of printing Conference Proceedings

\section{EXPENDITURE}

Printing and binding

Distribution and postage

Airfreight costs

20-Year Index

Loss on reprints

Microfiching back volumes

Editorial expenses

Administration expenses

Transfers to other Funds:

Publications and Journals

Development Fund

Research and Education Fund

EXCESS OF INCOME OVER EXPENDITURE

Fluctuations IN RATES OF EXCHANGE

ACCUMUlated balance AT THE END OF THE YEAR
1987

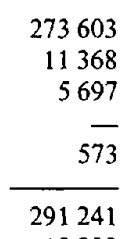

19932

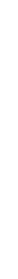

1988

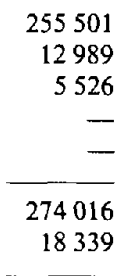

271309

430

$\frac{-}{271739}$

77160

8996

3985

2745

59793

13721

30000

20000

$\begin{array}{r}216400 \\ \frac{55339}{-20318} \\ \hline 364612 \\ \hline\end{array}$

1989

$\begin{array}{r}266492 \\ 12166 \\ 7691 \\ 1428 \\ 253 \\ \hline 255677 \quad 288030 \\ \hline\end{array}$

268424

10800

266477

127562

12322

5015

$75 \overline{42}$

2760

83580

16059

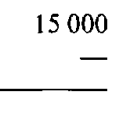

225717

42707

$+17306$

442674

Table 8. Structure Reports (Swiss Francs)

INCOME

Sale of copies

Less Publisher's commission

EXPENDITURE

Printing and binding new volumes

Typing of manuscripts

Editorial expenses

EXCESS OF INCOME OVER EXPENDITURE

FLUCTUATIONS IN RATES OF EXCHANGE

ACCUMUlated BALANCE AT THE END OF THE YEAR
1987

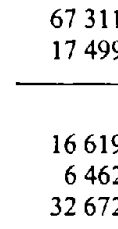

67311

7499

49812

69510

19205

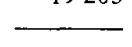

14761

8500

61619

1988

1989

\begin{tabular}{rrr}
50305 & $\begin{array}{r}213499 \\
55510\end{array}$ & 157989 \\
& & \\
& $\begin{array}{r}46450 \\
13593\end{array}$ \\
\hline 84880 & 37181 & \\
\hline-34575 & & $\frac{97224}{60765}$ \\
\hline+3819 & & +5249 \\
\hline 68246 & & +34260 \\
\hline
\end{tabular}

of the sales income in a particular year, are for the volumes published in that year, i.e. Volumes $51 \mathrm{~A}$ and $52 \mathrm{~A}$ in 1987 , Volumes $50 \mathrm{~A}$ and $53 \mathrm{~A}$ in 1988 and Volumes $49 \mathrm{~A}, 49 \mathrm{~B}$ and $54 \mathrm{~A}$ in 1989. The other expenses of a year always include editorial work for several volumes yet to be published.

In 1986 the EC decided to discontinue the publication of the Organic Compounds volumes of Structure Reports after the publication of the volume for 1985 (Volume 52B). Furthermore, it was decided to continue with the Metals and Inorganic volumes in a modified format, and to explore ways of collaborating in the production of these volumes with the inorganic and metals crystallographic databases. The Chairman of the Commission on Structure Reports agreed to inform the $\mathrm{EC}$ as soon as he considered that the time was ripe to discontinue the Metals and Inorganic Compounds volumes of Structure Reports also, and let conveniently accessible database information take over. With these changes, the editorial costs will decline in the 
Table 9. International Tables (Swiss Francs)

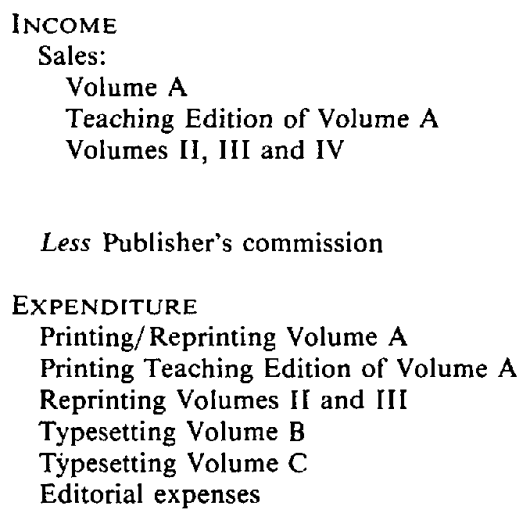

EXCESS OF INCOME OVER EXPENDITURE

FLUCTUATIONS IN RATES OF EXCHANGE

ACCUMULATED BALANCE AT THE END OF THE YEAR
1987

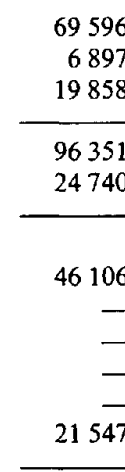

Table 10. Book Fund (Swiss Francs)
1987

INCOME

Sale of copies (net):

Escher kaleidozyklen

Crystallographic Databases

Fifty Years of X-ray Diffraction

Escher Drawings

Early Papers

Fifty Years of Electron Diffraction

World Directory of Crystallographers:

7 th edition

Sundry publications

Royalties:

Escher Drawings

Book Series. IUCr Crystallographic Symposia

EXPENDITURE

Escher kaleidozyklen

Crystallographic Databases

Book Series expenses

Historical Atlas of Crystallography

World Directory of Crystallographers: 8th edition

EXCESS OF INCOME OVER EXPENDITURE

Fluctuations in Rates of EXChange

ACCUMULATED BALANCE AT THE END OF THE YEAR
1988

1989

\begin{tabular}{|c|c|c|c|c|}
\hline & $\begin{array}{r}82636 \\
9797 \\
31243\end{array}$ & & $\begin{array}{r}77731 \\
6771 \\
35097\end{array}$ & \\
\hline 71611 & $\begin{array}{r}123676 \\
32035\end{array}$ & 91641 & $\begin{array}{r}119599 \\
31073\end{array}$ & 88526 \\
\hline 67653 & $\begin{array}{r}7523 \\
- \\
8321 \\
16643 \\
25448\end{array}$ & 57935 & $\begin{array}{r}34905 \\
7580 \\
26362 \\
9559 \\
14339 \\
47648\end{array}$ & 135303 \\
\hline $\begin{array}{l}-3958 \\
-9523\end{array}$ & & $\begin{array}{r}33706 \\
+12127\end{array}$ & & $\begin{array}{r}-46867 \\
+6911\end{array}$ \\
\hline 170896 & & 216729 & & 176773 \\
\hline
\end{tabular}

1989

1988

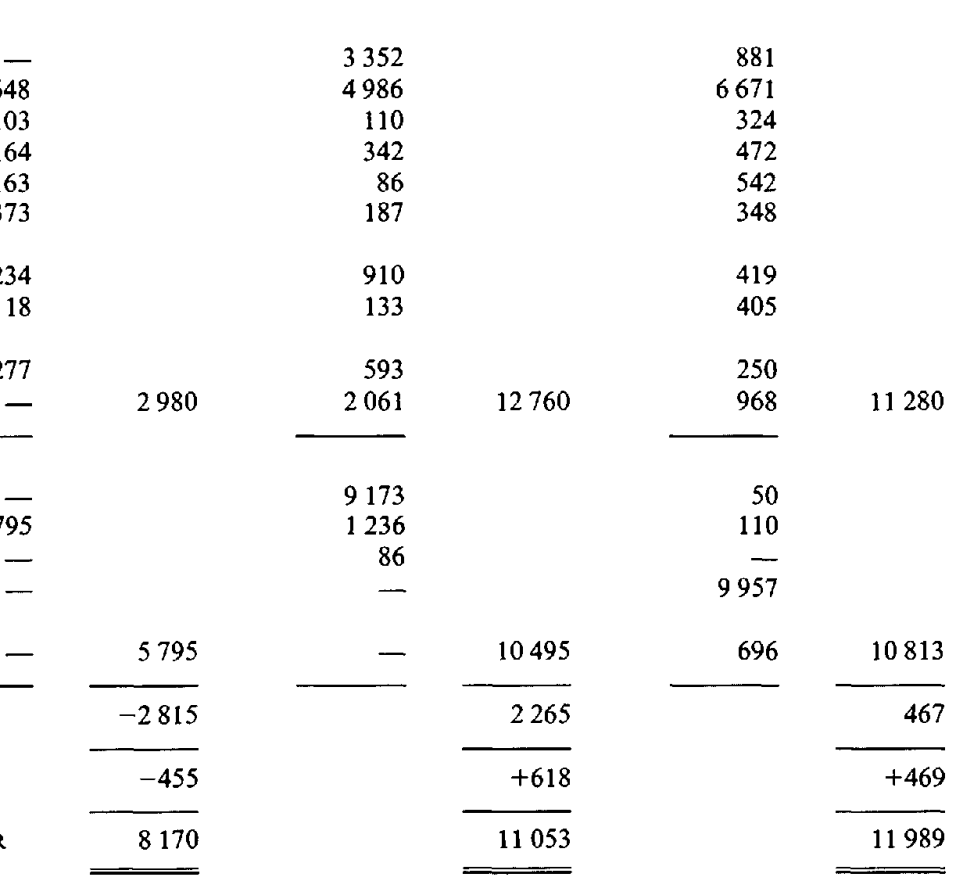

near future and that gives reason to believe that the balance of the Structure Reports accounts will remain positive. For further details see the Triennial Report by the Chairman of the Commission on Structure Reports.

\section{International Tables}

The International Tables accounts are shown in Table 9. The sales figures there show that there have been rather constant sales of Volume A, the Teaching Edition of Volume $A$, and Volumes II, III and IV during the triennium.
The costs connected with the printing and reprinting of the second edition of Volume A are charged to the 1987 and 1989 accounts, respectively, and the costs connected with reprinting Volumes II and III are charged to the 1989 accounts. The editorial expenses for the triennium are mostly related to the work on the two new volumes, Volumes $B$ and $C$. The accounts for 1988 and 1989 also include expenditure on the typesetting of these two volumes. For further details see the Triennial Report by the Chairman of the Commission on International Tables. 
Table 11. Molecular Structures and Dimensions (Swiss Francs)

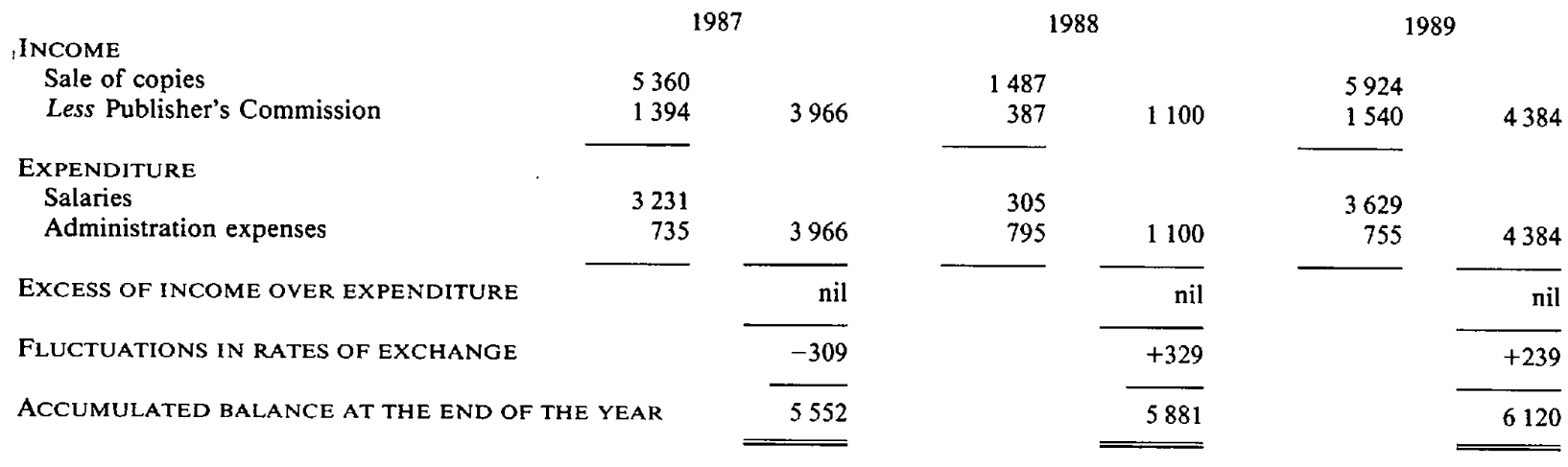

Table 12. Publications and Journals Development Fund (Swiss Francs)

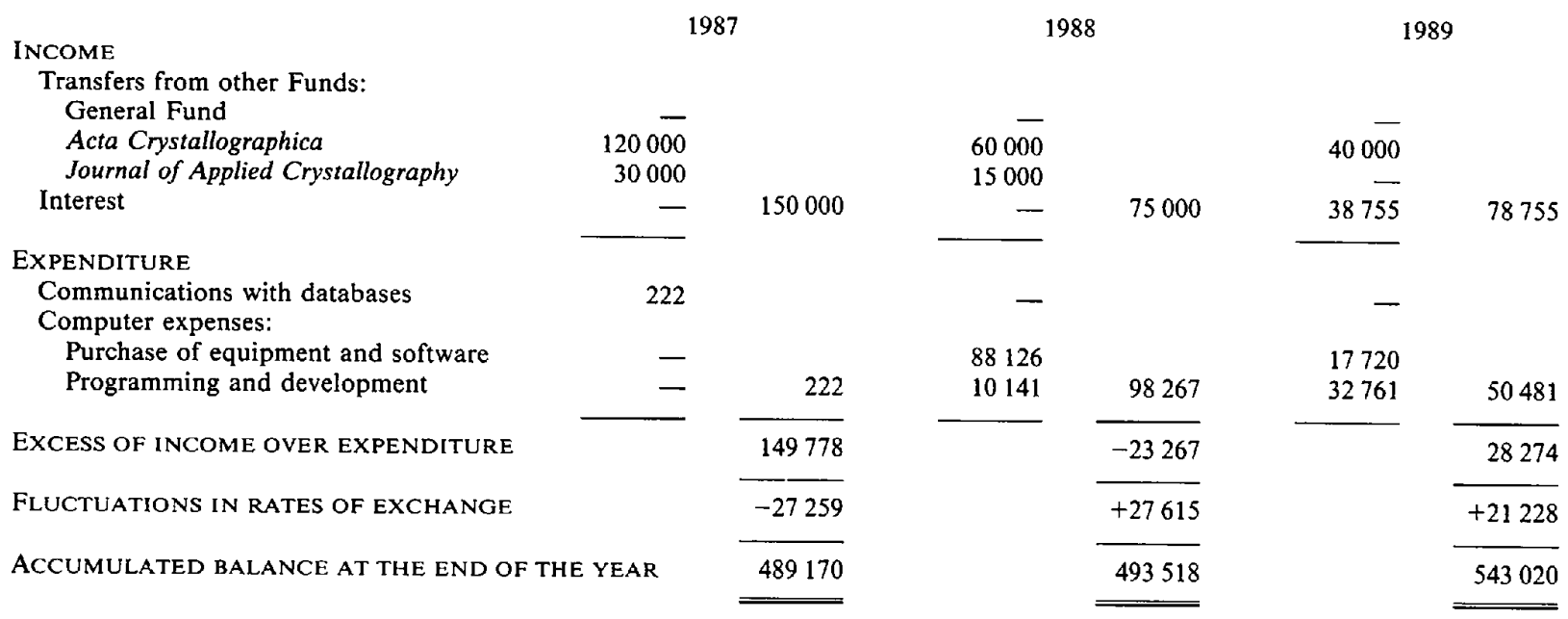

\section{The Book Fund}

Table 10 gives the accounts of the Book Fund. The increase in the accumulated balance of this fund during the triennium is small, and the numbers are compatible with those given for the 1984-86 triennium [Acta Cryst. (1988), A44, 587].

\section{Molecular Structures and Dimensions}

The Molecular Structures and Dimensions accounts are shown in Table 11. One notes that the income and expenditure shown in the accounts balance exactly. This is according to an agreement between the Cambridge Crystallographic Data Centre and the IUCr. See Acta Cryst. (1988), A44, 588 for further information.

\section{Publications and Journals Development Fund}

Table 12 shows the accounts of the Publications and Journals Development Fund (PJDF). The fund was established in 1984 and has been built up through transfers from other funds, such as $\mathrm{AC}$ and JAC. In order to build up the fund further and in a systematic way, with the goal to make it 'self-supporting', the EC decided to increase its balance by crediting it with interest calculated as $8 \%$ of the balance in the fund, from 1989 onwards, as shown in Table 12.
Furthermore, one notes from that table that the main expenses during the triennium are related to the purchase of computer hardware and software and, to a smaller degree, to programming and development.

It is the EC's policy to support and encourage the IUCr's highly qualified staff by supplying them with the best equipment.

\section{Research and Education Fund}

Table 13 shows the account of the Research and Education Fund (REF). The fund was also established in 1984 and, like the PJDF, has been built up through transfers from other funds. As for the PJDF, the EC decided to increase this fund by $8 \%$ per year, taken from the interest income, with the goal to make it 'self-supporting'. One notes that about CHF 190000 was given as young scientists' support during the triennium.

\section{Ewald Fund}

The accounts of the Ewald Fund are given in Table 14. The last transfer to the fund was in 1987 , being a transfer from the General Fund of an amount comparable with the funds received in that year from the Ewald family. The interest on the capital is intended to cover the costs of the 
Table 13. Research and Education Fund (Swiss Francs)

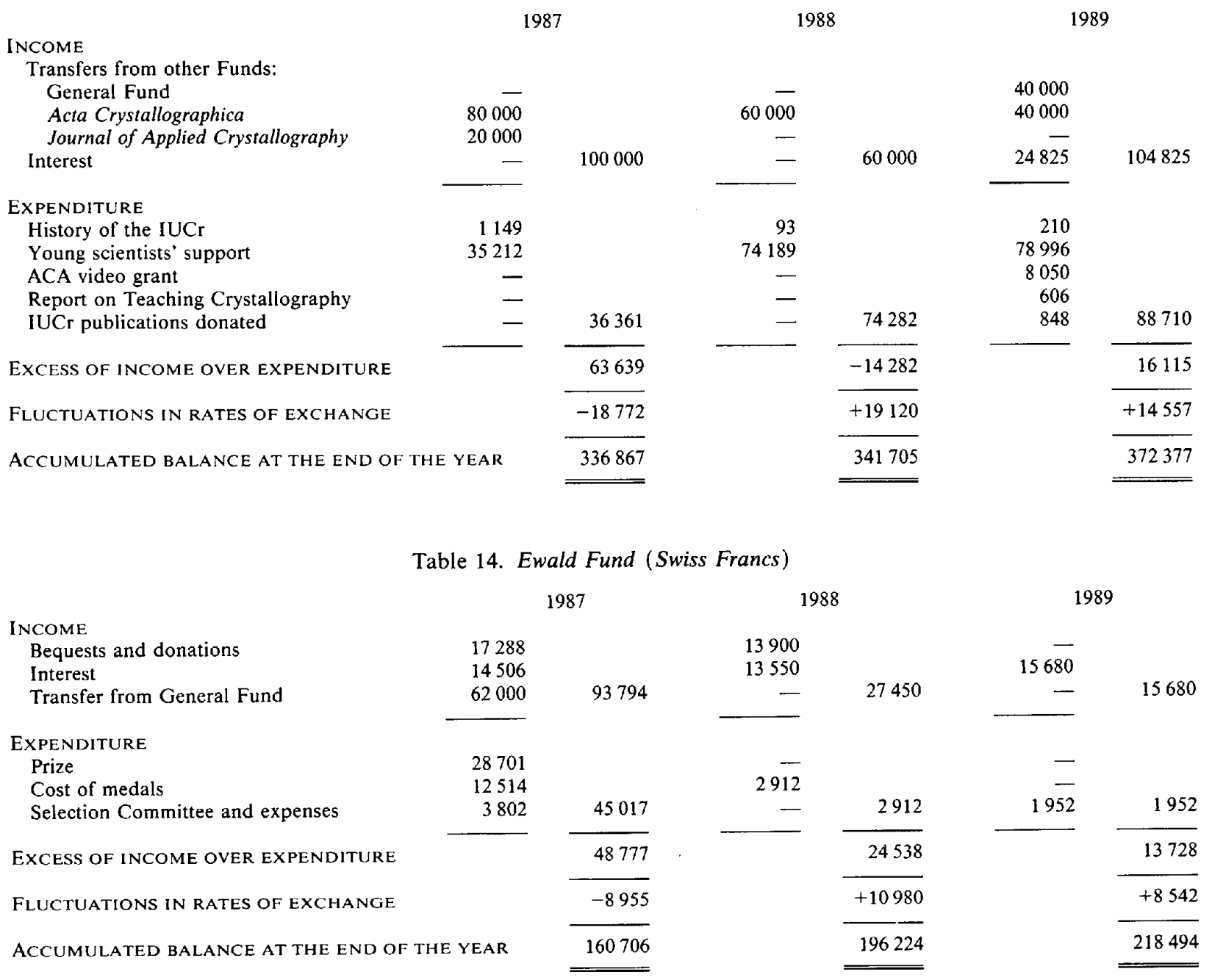

Prize. It is calculated as $8 \%$ of the balance in the fund, and is taken from the total annual interest income received from the IUCr's investments, in the same way as for the interest credited to the PJDF and the REF. The balance of the interest from the investments is credited to the GF.

\section{Appendix C: Ewald Prize}

The establishment of the Ewald Prize, for outstanding contributions to the science of crystallography, was announced in February 1986 and was given wide publicity. The name of the Prize was chosen with the kind consent of the late Paul Peter Ewald, to recognize Professor Ewald's significant contributions to the foundations of crystallography and to the founding of the International Union of Crystallography, especially his services as the President of the Provisional International Crystallographic Committee from 1946 to 1948, as the first Editor of the IUCr's publication Acta Crystallographica from 1948 to 1959 , and as the President of the IUCr from 1960 to 1963.

Shortly after the death of Professor Ewald, his family informed the President that Professor Ewald had wished to make a bequest to the IUCr. After consulting Mrs Ewald, this generous bequest, together with a donation from the Ewald family and a further donation from the IUCr, was used as capital for the Ewald Prize. The interest from this capital is used to finance the Prize.

The Prize consists of a medal, a certificate and an award of US $\$ 20000$. It is presented once every three years during the triennial International Congress of Crystallography. The first Prize was presented during the Perth Congress, being awarded jointly to Professor J. M. Cowley and Dr A. F. Moodie.

In April 1990 it was announced that the second Ewald Prize, for outstanding contributions to the science of crystallography, had been awarded to Professor B. K. Vainshtein for his contribution to the development of theories and methods of structure analysis by electron and X-ray diffraction and for his theories to structural investigations of polymers, liquid crystals, peptides and proteins.

Professor Boris Konstantinovich Vainshtein is a full member of the USSR Academy of Sciences, and is Director of the Institute of Crystallography, the USSR Academy of Sciences, Lenirnsky prospekt 59, 117333 Moscow, USSR. 
The presentation of the Ewald Prize to Professor Vainshtein will be made during the Congress Opening Ceremony on 19 July. Professor Vainshtein will give a General Lecture on the evening of $26 \mathrm{July}$.

\section{Appendix D: Reports of the Commissions of the Union}

\section{Commission on Journals}

Acta Crystallographica and the Journal of Applied Crystallography have been published on or close to schedule throughout the triennium. The Commission approved a new category of paper, Fast Communications, for Acta Cryst. Section A, that appeared in January 1989, at which time Section $A$ was also conveited to a monthly publication. The Fast Communications section is to be used for reporting (within three or four months of receipt) important results in all areas of crystallography, as well as for printing Letters to the Editor, reports from other IUCr Commissions and other items relating to IUCr policies. Seven of these papers were published in 1989 within an average publication time of 1.4 months. The Short Format papers in Section C, initiated in 1985, continue to increase: from eight papers published in 1985, the number increased to 239 in 1989.

Commitments have been made by selected authors for publication of 17 future Lead Articles in Acta Cryst. and seven in J. Appl. Cryst. The five-year cumulative indexes for Acta Cryst. for the period 1983-1987 were distributed in December 1989, and were prepared in-house in Chester and sent to the printer as camera-ready copy. The 20-year $J$. Appl. Cryst. index for the period 1968-1987, similarly prepared, will be complete in 1990.

The total number of papers in Acta Cryst. in this triennium was $21 \%$ more, at 3426 , than in the previous triennium, and that in J. Appl. Cryst. was $26 \%$ more, at 399 . The increase in J. Appl. Cryst. reflects the 'Small-Angle Scattering' issue in 1988 that resulted in an additional 69 papers for that year. Papers from 57 different countries have been published in the triennium. Mean times between published acceptance and nominal publication dates for full papers were 5.1 months for Section A, 5.2 months for Section B, 4.9 months for Section C and 5.4 months for J. Appl. Cryst. The backlog of Section C structural papers in the Technical Editor's office, which resulted in an increase in publication time for this section, is expected to lessen with the installation of new computer facilities, planned expansion of the staff in the Technical Editor's office, and the development of centralized checking routines.

Subscription rates (in Danish kroner) remained constant during the triennium, with an institutional cost in 1989 of 3.9 US cents per 1000 characters for Acta Cryst. and 5.2 US cents per 1000 characters for J. Appl. Cryst. While the number of subscribers taking all three sections of Acta Cryst. decreased slightly by $4 \%$, the number of subscriptions to the individual sections increased. J. Appl. Cryst. subscriptions declined slightly, $2 \%$, during the triennium.

Acta Cryst. Co-editors appointed during the triennium were J. Albertsson, B. M. Craven, G. Ferraris, A. Gavezzotti, J. P. Glusker, R. O. Gould (Book-Review Editor), M. M. Harding, P. F. Lindley, K. W. Muir, C. Pascard, W. H. E. Saenger and J. C. H. Spence, Retiring Co-editors were R. Colella, J. Drenth, G. Ferraris, M. Hospital, M. Nardelli, C. E. Nordman, R. Norrestam, J. H. Robertson (BookReview Editor) and B. T. M. Willis. C. E. Bugg succeeded
S. C. Abrahams as Editor of Acta Cryst. following the Perth Congress in 1987. G. Kostorz retired as a Co-Editor of $J$. Appl. Cryst. The Commission greatly appreciates the time spent by the Co-editors in performing their editorial and administrative duties, and looks forward to their help with the journals during the next triennium.

Staff changes in the Technical Editor's office in Chester during the triennium included the departure of A. J. Sharpe and the appointment of S. R. Anderson, A. S. Berry and M. Hurst as Editorial Assistants and C. Cash as part-time Secretary. Because of his excellent work implementing checking software and making preparation for the banking of structural data at Chester, B. McMahon was appointed Editorial Assistant and Computer Supervisor. The editorial staff will be increased during the coming triennium due to the increased use of in-house computing facilities for checking and archiving of structural data. The Commission commends all members of th : Technical Editor's staff for their excellent and loyal work.

6 April $1990 \quad$ C. E. BugG, Chairman M. SCHLENKER, Co-Chairman

\section{Commission on Structure Reports}

Volume 49A (Metals and Inorganic Compounds for 1982 , 396 pages), Volume 50A (Metals and Inorganic Compounds for 1983, 381 pages), Volume 51A (Metals and Inorganic Compounds for 1984,384 pages), Volume 53A (Metals and Inorganic Compounds for 1986, 287 pages), Volume 54A (Metals and Inorganic Compounds for 1987, 328 pages) and Volume 55A (Metals and Inorganic Compounds for 1988,320 pages) have been published. Volume 49B (Organic Compounds for 1982,1861 pages in two volumes) has been published. Co-editorial work is nearing completion for Volumes $50 \mathrm{~B}$ and $51 \mathrm{~B}$, and is in progress for $52 \mathrm{~B}$ (Organic Compounds for 1983, 1984 and 1985 respectively). Material is being gathered for the Cumulative Index for 1971-1980 (Volume 47B).

4 March 1990

G. Ferguson, Chairman

\section{Commission on International Tables}

The Commission held an Open Meeting during the Perth Congress. Each Editor presented his plans for his Volume, and profited from the discussion. In addition, many formal and informal meetings between the Editors and Commissions took place, and the Editors were able to discuss many individual contributions with their authors, and to invite many new authors. Work continued actively throughout the triennium, chiefly by correspondence, though the Editors and a few others were able to meet occasionally at conferences and otherwise. The networks BITNET and EARN have been used to great advantage in speeding communications between the Editors and with some contributors. Early attempts at network transmission of contributions were only partially successful, primarily because of the great diversity of marking-up schemes and control characters. The problems can be overcome; see the report on Volume $B$.

Withdrawal of authors has posed problems for the Editors of Volumes B and C; several authors in each volume failed to meet their promised deadlines, and it was not possible to find suitable replacements in all cases. The IUCr Executive Committee considered the situation at its meeting 
Table 1. Sales and stocks of volumes published to date

\begin{tabular}{lccccc} 
Volume & \multicolumn{1}{c}{ II } & III & IV & A & Brief A \\
Date of publication & 1959 & 1962 & 1974 & 1983 & 1985 \\
Dates of reprinting & 1967 & 1968 & 1989 & 1984 & 1988 \\
& 1972 & 1983 & - & 1986 & 1989 \\
& 1985 & 1985 & - & 1987 & - \\
& 1989 & - & - & 1989 & - \\
Number of copies sold & & & & & \\
Up to 31 December & & & & & \\
$\quad 1986$ & 8825 & 8130 & 3663 & 2387 & 1266 \\
in 1987 & 99 & 71 & 80 & 400 & 490 \\
in 1988 & 135 & 124 & 134 & 455 & 591 \\
in 1989 & 110 & 112 & 104 & 370 & 360 \\
Up to 31 December & 9169 & 8437 & 3981 & 3612 & 2707 \\
$\quad 1989$ & & & & & \\
Stock at 31 December & 359 & 441 & 390 & 755 & 985 \\
$\quad 1989$ & & & & &
\end{tabular}

in July 1989, and interviewed the Editors of Volumes B and $C$ on 18 July. Though certain gaps in the original plans for these volumes still remained, it was felt that the contributions already received plus those that could be confidently expected within a few months would make acceptable publications. The Editors of Volumes $\mathrm{B}$ and $\mathrm{C}$ were therefore instructed to send to the Technical Editor the remaining section for publication, with an absolute deadline of 31 December 1989 , and to hold over to a second edition any contributions still outstanding at that date. Reports on the individual Volumes A-D are given below, and details of sales and stocks of Volumes II-IV and A are given in Table 1 .

During the triennium the Commission devoted much thought to possible future volumes. At the beginning of the triennium Volume $A$ had been in print for four years, and Volumes B and C were in preparation. Volume D (Physical Properties of Crystals) was authorized in September 1988. The following are the topics now under active consideration:

1. V. Kopsky and D. B. Litvin have prepared a detailed plan for a volume on Subperiodic Symmetry Groups. Their plan will be considered by the Commission and the Executive Committee at their meetings in Bordeaux in July 1990.

2. Much time has been spent by the Chairman of the Commission and others within the IUCr in studying the practicability of preparing a volume on multidimensional crystallography. The quantity of material makes it difficult to plan even a volume on four-dimensional crystallography, and it is not entirely clear whether the theory is complete for higher dimensions. The subject is very important in connection with modulated structures and quasi-crystals, and the Commission hopes to be able to make definite proposals at Bordeaux.

3. Discussion continued on two other proposals (Crystallographic Computing and Mathematics for Modern Crystallography). During the 1989 Executive Committee meeting, the Editor of Volume B put forward outline proposals for these volumes. Such volumes are likely to be of great value to the crystallographic community, but the appropriate format needs further consideration. The formats so far considered are (i) Volumes of International Tables and (ii) Monographs, such as those in the IUCr/Oxford University Press series: IUCr Monographs on Crystallography. This question will be further discussed during the Bordeaux meetings of the Commission.
Volume A (Space-Group Symmetry; Editor Th. Hahn)

The following editions and reprints of Volume A were published in the period 1987-1989:

1. The second, enlarged and fully revised, edition appeared in June 1987 and was displayed at the Perth Congress, when its features were explained during the Open Meeting of the Commission.

2. A second list of Errata in the first edition $(1983,1984)$ was published in Acta Cryst. (1987), A43, 836-838.

3. A reprint of the second (1987) edition with corrections was published in May 1989.

4. The second edition of the Brief Tecching Edition was published in February 1988.

5. The second (1988) edition of the Brief Teaching Edition was reprinted with corrections in September 1989.

Preparation of new or revised diagrams was begun, and the new diagrams were incorporated in the reprinted editions as they became available. The 1989 reprint contains new diagrams for the plane groups, the tetragonal crystal class $4 / \mathrm{mmm}$ and the trigonal and hexagonal space groups. The remaining tetragonal diagrams were completed in December 1989 and the cubic diagrams are being thoroughly revised.

Preparations for a third revised edition of Volume $A$ are under way, with two main objectives: (1) incorporation of new or revised diagrams for all space groups, and (2) a more detailed characterization of the subgroups of the space groups with respect to conjugacy relations and conjugating elements.

\section{Volume B (Reciprocal Space; Editor U. Shmueli)}

The earlier part of the triennium was devoted to the commissioning and collection of contributions, the latter part to reviewing and editing them, and to the completion of the Editor's own contributions. It appears that Volume B will consist of 19 chapters, comprising a selection of mathematical and statistical methods of crystallography, methods of crystal-structure determination from X-ray and electron-diffraction data, computational and graphical treatments of crystal and molecular geometry, topics in crystal physics related to diffuse scattering and scattering from paracrystalline phases, and dynamical theories of $X$-ray and electron diffraction. Two contributions are still in the final stages of revision, and four invited contributions have been postponed to a later edition of the volume.

The possibility of transferring via electronic mail almost arbitrarily complicated texts manifested itself to the Editor during the period of this report. It should be pointed out that most scientific word processors are equipped with relevant translating routines, and transmission of scientific material between author and editor, via this route, is a convenient and rather inexpensive proposition. It requires that transmitter and receiver use jdentical systems.

Volume C (Mathematical, Physical and Chemical Tables; Editor A. J. C. Wilson)

Volume $C$ has presented problems rather different from those of Volume B. Volume C was originally planned as an editorial condensation of the existing Volumes II, III and IV, with obsolete or readily available material eliminated, and tables for which a pocket calculator would be an acceptable substitute reduced to a skeleton tabulation. Consultation with the Chairmen of relevant Commissions, 
however, convinced the Editor that much fundamental rewriting would be necessary if Volume $\mathrm{C}$ were to be a worthy companion to Volumes $\mathrm{A}$ and $\mathrm{B}$. The material is widely disparate, and it was therefore necessary to invite a large number of authors to contribute, some of them responsible for only a couple of pages, others for substantial chapters. A few gaps in the original plan remained at the expiry of the deadline set by the Executive Committee; some are being filled by condensation and updating of material from Volumes II-IV.

Volume D (Physical Properties of Crystals; Editor B. T. M. Willis) [Since this report was prepared $\mathrm{Dr}$ Willis has resigned.]

Work on Volume D officially began in September 1988, though preparations had begun considerably earlier. The Table of Contents was approved by the Executive Committee and is published in Acta Cryst. (1989), A45, 753. It consists of six parts.

The first part, 'Mathematicai Introduction', is substantially complete. It is concerned with the use of tensors to represent the physical properties of crystals, at a level of presentation similar to that of the book Physical Properties of Crystals by J. F. Nye (1985). The last chapter in this part deals with the reduction in the number of independent components of a tensor by the symmetry operations of the crystallographic point group.

The remaining parts describe the macroscopic properties of crystals, intrinsic or extrinsic. The intrinsic properties depend on the inherent nature of the crystal (structure, chemical composition etc.), whereas extrinsic properties are associated with faults (point defects, dislocation etc.). Most of the properties to be dealt with in Volume D are extrinsic. The second part, 'Mechanical Properties', is in first draft.

\section{March 1990 \\ A. J. C. WILSON, Chairman}

\section{Commission on Biological Macromolecules}

The three years since the Perth Congress have seen dramatic growth in macromolecular crystallography; the award of the Nobel Prize to the Munich group in 1989 for their analysis of the photoreaction centre underlines the scientific importance of the discipline and its contribution to biological science. The most pronounced expansion has been in North America where a number of new academic and industrial laboratories have been established, but there has also been an expansion in Europe, though to a somewhat lesser extent.

The growth of the subject has presented problems. First, there is a shortage of well trained crystallographers and steps must be taken to ensure that there are enough trained crystallographers in the future. Second, the growth of datacollection techniques and the power of computational procedures has meant that the analysis and refinement of protein structures, particularly mutant protein structures, can sometimes be carried out very quickly indeed, even by relatively inexperienced workers. Thus it is necessary to ensure that the rapidly growing amount of crystallographic information will be published in a useful way. Linked to this is the necessity of establishing criteria that demonstrate the correctness and the quality of the crystallographic determination. The Commission decided to draw up proposals for criteria, which will be considered at the Bordeaux
Congress. If accepted, these criteria will be widely publicized and sent to journals and referees.

As a result of the growth in X-ray studies of macromolecules, there have been many conferences and workshops over the three year period. Some of these have been outstanding and have taken place in many countries of the world. One practice, which is becoming more developed, is a workshop in which a small group of crystallographers concentrates on some aspect or technique in the discipline. Thus there have been workshops on synchrotron radiation, new techniques in refining molecular calculations and, always important, crystallization. The community is divided as to whether the growing of crystals in space is a promising option, but experiments continue and the expectation is that the advantages and disadvantages of this approach will soon be well understood. Finally, there are a growing number of short schools devoted to training and improving crystallographic skills for beginners in the field.

The Commission has produced a policy on the deposition of crystallographic data and it is hoped that this will ensure a uniform and fair practice throughout the community. In formulating its policy, the Commission and the community discussed different procedures and finally agreed to a policy in which atomic coordinates can be delayed for one year and structure factors for four years after publication, if the authors so wish.

\section{March 1990}

G. Dodson, Chairman

\section{Commission on Charge, Spin and Momentum Densities}

The Commission continues to encourage and promote work related to many aspects of electron-density distributions with emphasis on new fields of application, new experimental techniques and theoretical approaches for the interpretation of the data. The activities have been described in two Newsletters published in the Fast Communications section of Acta Crystallographica Section A and sent to all scientists on the 'Sagamore Mailing List'.

The most important activity of the Commission was the IX Sagamore Conference on Charge, Spin and Momentum Densities held at Luso, Portugal, in the summer of 1988. The special theme of the conference was the electronic structure of $3 d$ transition metals; attention was also given to $\mathrm{X}$-ray scattering experiments on magnetic materials. The conference programme included 18 invited lectures and about 60 poster contributions. There were approximately 100 participants. The conference proceedings will be published in Portugaliae Physica.

During the conference the Commission met to discuss its projects and the future of the Sagamore Conferences. It was agreed that these conferences are still very well suited for bringing together theoreticians and experimentalists and they should be continued. It was appreciated that those members of the Sagamore community who are specialists in new experimental or theoretical fields are able to explain their work in a language comprehensible to crystallographers. It was decided to hold Sagamore $\mathrm{X}$ in Konstanz, Federal Republic of Germany, in the summer of 1991.

Prior to Sagamore IX the Commission organized a twoday workshop on Density Matrices as Intermediates between Wavefunctions and Experiments in Coimbra, Portugal. One-particle density matrices are considered the most appropriate quantity for combining the information 
on the ground-state wavefunction obtained from chargeand momentum-density measurements. The nine invited lectures presented will be published in Portugaliae Physica.

As a result of the workshop, a new Commission project on Quantum Mechanical Description of Electronic Structure from Experimental Charge and Momentum Densities has been proposed. A project on Evaluation and/or Measurement of the Electron Density in Perovskite Structures has also been suggested. Both proposals will be discussed in a Commission meeting during the Bordeaux Congress.

For the Bordeaux Congress the Commission initiated microsymposia on Extinction and on The Use of Charge Densities in Computer Simulation and Molecular Design and is directly involved in planning an Open Commission Meeting on Accuracy of Experimental Electron Densities. 19 March 1990 J. R. SCHNEIDER, Chairman

\section{Commission on Crystal Growth and Characterization of Materials}

In the triennium 1987-90, the guidelines of the Commission have been to continue the expansion of crystalgrowth and crystallographic activities in the field of modern materials science, with the aim of proposing and underlining new interesting areas of potential involvement for the crystallographic community, especially as regards new materials (e.g. superconductors, electronic and biological materials), devices (e.g. superlattices and quantum-well devices) and technologies (e.g. epitaxy, microgravity). Many topics in science and technology are now seen to be dependent on various aspects of crystal growth, whose assessment is, in turn, largely dependent on the application of crystallographic tools. These facts, when coupled with the great diversity of activities and disciplines which are currently being drawn into crystal-growth research, offer a unique opportunity to introduce crystallography into the most advanced topics of materials science.

Hence the Commission has undertaken the following initiatives. Firstly, it recommended IUCr sponsorship and actively assisted in the organization of the First International Conference on Epitaxial Crystal Growth, which will be held in Budapest, Hungary, 1-7 April 1990, and will be concerned with all aspects of expitaxy, including new materials, technologies and characterization. Secondly, the Commission is organizing a microsymposium on Crystal Growth in Microgravity during the Bordeaux Congress. This microsymposium will concentrate on how crystallographic methods are expected to play a role in the structural definition of space materials, rather than on reports of new trends and developments as regards crystal growth in space.

The Commission has also continued the series of successful schools on crystal growth and crystallography, intended to provide information on fundamental and applied aspects to young scientists from developing countries. This series of schools, sponsored by the IUCr and organized by the Commission in the last decade, has been continued with an International School on Crystal Growth and Characterization of Advanced Materials, La Habana, Cuba, 30 November-10 December 1987, and an International School on Crystal Growth and Crystallographic Assessment of Industrial Materials, Sitges, Spain, to be held 13-25 May 1990.
The plans of the Commission to organize a school in India in 1988 had to be abandoned when no assurance could be obtained by the local organizers that the ICSU principles of free circulation would be adhered to. For the same reasons, the Commission could not recommend IUCr sponsorship of the International Conference on Crystal Growth (ICCG-9) or the International Summer School on Crystal Growth (ISSCG-7), both held in Japan under the auspices of the $10 \mathrm{CG}$. This situation created, and continues to create, difficulties for the Commission, as no further formal activities can be undertaken with two of the largest crystal-growth communities in the world, in developing and developed countries respectively, until the situation changes.

During 1988 the proceedings of two international schools organized by the Commission were published. They are Epitaxial Electronic Materials, edited by A. Baldereschi \& C. Paorici; Proc. Int. School on Technology, Characterization and Properties of Epitaxial Electronic Materials, Trieste, 13-24 January 1986; World Scientific, Singapore, London (1988), and Crystal Growth and Characterization of Advanced Materials, edited by A. N. Christensen, F. Leccabue, C. Paorici \& O. Vigil; Proc. Int. School held in La Habana, Cuba, 30 November-10 December 1987; World Scientific, Singapore, London (1988).

20 March 1990

C. PAORICI, Chairman

\section{Commission on Crystallographic Apparatus}

The Commission has as its prime function the study of factors which adversely influence the proper conduct of experiments and the interpretation of the data therefrom. For some time now the Commission has been directly concerned in the study of those parameters which are widely used by crystallographers, in which crystallographers place their trust, but in which their trust may be misplaced, viz $\mathrm{X}$-ray attenuation coefficients, anomalous-dispersion corrections, X-ray emission wavelengths. It has received requests from the Commissions on Journals and on International Tables for assistance in solving problems faced by these Commissions. It seeks to redress problems associated with the use of specific instrumental techniques [e.g. singlecrystal X-ray diffraction and X-ray absorption fine structure (XAFS)]. The Commission is also involved from time to time in the organization of specialist meetings and workshops. It it expected that members of the Commission will take an active part in at least one of its projects.

In the present triennium the Commission has been engaged in the following activities:

1. The X-ray Attenuation Project (D. C. Creagh and J. H. Hubbell)

Although this project commenced more than a decade ago, it still excites interest and a number of laboratories throughout the world are involved in experiments using the standard specimens. Two papers have been published [Creagh \& Hubbell (1987). Acta Cryst. A43, 102-112; Creagh \& Hubbell (1990). Acta Cryst. A46, 402-408] and others are planned. The experience gained in conducting this project was invaluable for the production of a contribution to Volume $\mathrm{C}$ of International Tables for Crystallography. 
2. The Single-Crystal Lattice Parameter Project (G. de Titta and S. Martinez-Carrera)

The necessary steps to set up this project have been completed. About 20 laboratories have indicated that they would be interested in participating. The project is now at the stage where careful examination and characterization of specimens to be used in the project are taking place. It is noteworthy that two national bodies have thought fit to hold workshops or conferences on the subject of accuracy in lattice-parameter measurement.

3. The Accuracy in XAFS Project (G. Materlik, R. Frahm, H. Oyanagi, J. Wong and D. C. Creagh)

This project commenced with an enquiry from the Commission on Journals regarding the inadequate presentation of XAFS papers in journals. A further initiative by the XAFS standards committee, of which I am a member, confirmed that this project was timely. As with all of the Commission's projects, the participation of a wide range of laboratories in a collaborative project is the key to success. Before such a project can be undertaken, laboratories have to indicate their willingness to cooperate and specimen materials have to be acquired, characterized and tested. The first set of such specimens was tested by Oyanagi and Creagh in Japan in 1989 and some materials were found to be inadequate as test materials. Further discussion on the matter will be undertaken at the XAFS VI Conference (August 1990, York, England) and further experimentation is scheduled in May 1990 (DESY) and November 1990 (Photon Factory).

4. International Tables for Crystallography, Volume $C$

One of the paradoxes of modern times is that, whilst the standard of instrumentation available has reached unprecedented heights of reliability, accuracy and reproducibility, the quality of the information used in the analysis of the data is inferior. People who are interested in improving this situation are involved in the time-consuming task of producing data for new sets of tables. The Commission has been involved in the production of sections on X-ray spectroscopy, X-ray absorption, anomalous dispersion and radiation safety, and sought to initiate a project to remeasure a number of X-ray wavelengths tabulated in Volume IV of International Tables for $X$-ray Crystallography, which were thought to be in error. Unfortunately, insufficient funds were available to undertake this project, although a demonstrable need exists for better, more accurate, data.

5. Possible Inter-Congress Conference on Anomalous Scattering (G. Materlik)

Professor Materlik is investigating the possibility of holding an Inter-Congress Conference on Anomalous Scattering. The anomalous-dispersion corrections have become very important parameters in X-ray diffraction experiments, and a conference would be of great benefit to the crystallographic community. The Inter-Congress Conference which was held in Madrid in 1974 stimulated wide interest and promoted the use of anomalous-scattering techniques in $\mathrm{X}$-ray diffraction experiments. It is believed that the proposed conference would have a similar beneficial effect.

6. Open Commission Meeting - Bordeaux (H. Hashizume and D. C. Creagh)

As a result of enthusiastic activity by Professor Hashizume, nearly 200 abstracts have been received for this meeting on Area Detectors in X-ray Diffraction.

Since the Perth General Assembly the Commission has been host to two special committees, the High Pressure
Group and the Inter-Commission Committee on Synchrotron Radiation, the latter being organized jointly with the Commission on Neutron Diffraction.

(i) The High Pressure Group (H. Schulz) organized a highly successful workshop in Munich in 1989, following the AIRAPT meeting in Paderborn, Federal Republic of Germany. 82 participants from 13 countries attended the Workshop on Crystal Structure Determination at High Pressure - Future Developments. It was most encouraging that 15 young scientists took part. This augurs well for the future of this group.

(ii) The Inter-Commission Committee on Synchrotron Radiation was set up to establish the need, or otherwise, for a separate IUCr Commission on Synchrotron Radiation, but it never really started to function. This led the IUCr Executive Committee to decide in July 1989 to set up such a Commission on an ad interim basis until the Bordeaux General Assembly. The Inter-Commission Committee has therefore been disbanded.

It is hoped that during the next triennium the Commission will continue its interest in the provision of the best compilations of fundamental parameters and its investigations into sources of inaccuracies in important experimental techniques.
16 March 1990
D. C. CREAGH, Chairman

\section{Commission on Crystallographic Computing}

In the second half of 1987 the main activities of the Commission were focused on presentations at the Perth Congress and at the following Winter School on Crystallographic Computing in Adelaide, South Australia. In Perth the Commission organized an Open Meeting jointly with the Commission on Crystallographic Teaching, around the theme 'Microcomputers in Crystallography'. It was a very popular theme with a large number of participants. The programme consisted of many different applications, from number crunching via experiment control to teaching. Another attractive item was the jointly organized Microcomputer Laboratory. Ten micros were available for the participants to show and test software. This was also very successful and will be repeated in Bordeaux. In two Closed Commission Meetings the policy for the coming three years was decided. The Commission appointed new editors for the Computer Program Abstracts section in the Journal of Applied Crystallography and H. D. Flack conducted a campaign to popularize this section amongst program authors.

In Adelaide the local organizers, under the chairmanship of M. R. Taylor, ran an outstanding Winter School on Crystallographic Computing. Over 100 participants gathered and enjoyed the way Dr Taylor and his crew put the school together. There was a very relaxed atmosphere which helped the programme, compiled by a committee led by $\mathrm{N}$. W. Isaacs, including the practical work sessions which were most useful because of the many different computer options available. Papers presented at the school have been published under the title Crystallographic Computing 4. Techniques and New Technologies, as Volume 3 in the joint IUCr/Oxford University Press series of IUCr Crystallographic Symposia.

The Commission planned a new school in France in 1990 with D. Moras as Programme Chairman. After very long discussions, the character of the school changed more and 
more from that of a traditional school to that of a symposium. This compromise appeared necessary to attract protein crystallographers. The school will be held in the week after the Bordeaux Congress, with a programme covering the computing side of small-molecule and protein crystallography.

Members of the Commission participated in joint interCommission activities, in particular for data file structures. The Commission looked into the possibility of running a bulletin board with downloading facilities for software in EARN or BITNET. Although at least one computer centre has been found willing to house the bulletin board, the Commission was not able to establish the necessary infrastructure to set'up the actual board and to guarantee its maintenance. This is a major job, not easily absorbed into anyone's daily work. The Commission will organize an Open Commission Meeting in Bordeaux, and found in Y. Epelboin a very enthusiastic co-worker to set up a computing laboratory at the Congress where the most popular microcomputers and workstations will be available for participants to demonstrate their newest software. Discussions in the Commission are under way with regard to the problem of commercial software versus public domain/shareware software. This may be a problem in the future. However, it is not expected to become as serious as in molecular modelling.

17 April 1990

H. SCHENK, Chairman

\section{Commission on Crystallographic Data}

\section{Meetings of the Commission}

The Commission organized two Open Meetings (one jointly with the Commission on Journals) and one Closed Meeting at the Perth Congress, and was responsible for coordinating computerized database demonstrations at the Congress. Informal meetings were also held at ECM-11 in Vienna in September 1988, and at the ACA Meeting in Seattle in July 1989. The Commission gave some informal assistance to the organizers of a Workshop on Inorganic Databases held in association with ECM-11. A microsymposium on Machine-Readable Submission of Crystallographic Data to Journals and Databases has been organized for the Bordeaux Congress, in collaboration with the Commission on Journals.

2. Publications and reports

A monograph entitled Crystallographic Databases was prepared and published by the Commission in 1987. It has now sold over 350 copies and its production costs have been recovered from sales. The possibility of an updated edition for publication in 1993 has been discussed. The report on Standardization of Crystallographic Unit Cell Data was discussed at the Perth Congress and ECM-11 in Vienna. It is hoped to finalize it at the Bordeaux Congress.

3. Commission recommendations

The card-image Standard Crystallographic File Structure SCFS-87 was approved by the Commission at the Perth Congress. A recommendation that fax and e-mail addresses be included in the next edition of the World Directory of Crystallographers was approved and communicated to the Gerieral Editor.

4. Machine-readable submissions to Acta Crystallographica and to crystallographic databases

The desirabitity of a free-format Crystallographic Information File (CIF) to expedite data capture by Acta
Cryst. and by the databases was first discussed at the Perth Congress. Since that time, very considerable progress has been made, in collaboration with the IUCr Commission on Journals and the Working Party on Crystallographic Information. A free-format CIF, based on the STAR (Selfdefining Text Archive and Retrieval) concept of S. R. Hall has been developed. Descriptor names have been established for a broad spectrum of crystallographic information types, drawing on the experiences with the Standard Crystallographic File Structure (SCFS) compiled by I. D. Brown. The expertise of Commission members has been sought in covering major structural areas, i.e. metals/alloys, inorganic/minerals, molecular compounds and proteins, and some work on generalization remains to be done. Precise definitions for most descriptors have been drawn up and will be finalized in time for the Bordeaux Congress. The STAR concept has been modified as a result of this practical application. A test manuscript, including a discussion section, has been transferred by electronic mail to the Chester office. It has been successfully processed to camera-ready copy for Acta Cryst. by desktop publishing software. The Commissions on Crystallographic Data and on Journals and the Working Party are now examining the systematics of CIF submissions on a routine basis. Authors of structuredetermination software packages are being asked to generate structural results in CIF format, as a basis for the complete machine-readable manuscript. This is an ongoing project which will continue to develop in the next triennium.

19 March 1990

F. H. Allen, Chairman

\section{Commission on Crystallographic Nomenclature}

The Commission has conducted its work during the last triennium either by letter or by electronic mail, with its principal activities having been carried out by its three committees, all of which completed their charges and published their final reports during this period.

The Subcommittee on Statistical Descriptors in Crystallography (Chairman: D. Schwarzenbach) published its report in Acta Cryst. (1989), A45, 63-75. In addition to providing a definition of the major statistical terms used in papers on crystallography, the report discusses the statistical basis upon which crystal-structure-refinement procedures depend, considers the influence of defects in the model used for refinement and the choice and significance of the weighting schemes employed and makes a series of recommendations designed to improve the use of statistical methodologies in crystallography.

The ad hoc Committee on the Nomenclature of Symmetry (Chairman: P. M. de Wolff) published its report entitled 'Definition of Symmetry Elements in Space Groups and Point Groups' in Acta Cryst. (1989), A45, 494-499. The report redefines symmetry elements in terms of their fundamental and carefully defined geometric elements. The work of the ad hoc Committee was extended during the year by charging it with considering the recommendation of printed and graphical symbols for symmetry elements.

The Subcommittee on the Nomenclature of Inorganic Structure Types (Chairman: J. Lima-de-Faria) published its report in Acta Cryst. (1990), A46, 1-11. The report develops a self-consistent nomenclature of crystal-chemical formulas that offers much greater structural insight for inorganic materials than is possible with traditional chemical formulas. 
Following extensive electronic communication, the Commission voted in late February 1990 to form a new Subcommittee on the Nomenclature of $N$-Dimensional Crystallography.

Close contact has been maintained throughout the triennium with a number of international bodies concerned with nomenclature matters.

13 March 1990

S. C. Abrahams, Chairman

\section{Commission on Crystallographic Teaching}

\section{Teaching Schools}

A Summer School, sponsored and financially supported by the IUCr, was held in Tianjin, People's Republic of China, 15-24 September 1988. There were approximately 20 teachers and 90 students, of whom 80 were from China. The Local Chairman was F.-m. Miao of Tianjin Normal University, Several Commission members participated. The sessions consisted of lectures followed by tutorial sessions, so that each student could receive as much attention as possible.

A Winter School was held in Bangkok, Thailand, 7-15 February 1990, at Chulalongkorn University. The Local Chairman was P. Phavanantha of Chulalongkorn University. Many aspects of crystallography, particularly those involving minerals and natural materials, were taught. There were 120 students from 14 different countries, including 78 from Thailand. The lectures on the first day were held jointly with a meeting of natural products chemists. Since Thailand is famous for its gemstones, many aspects of teaching involved these.

2. The IUCr Visiting Professorship Programme

Information on this programme, initiated by H. Schenk, is being circulated widely to many countries. Different countries and organizations have their own specific requirements for input of crystallographic teaching. The Thailand Winter School resulted from a preliminary investigation of a possible Visiting Professorship there, but it was shown that there was sufficient interest for a school to be held instead. Some locations for Visiting Professors are currently being considered, including the People's Republic of China.

3. Congress activities

A session on The Teaching of Crystallography; How to Engage and Encourage Science Students of the 1990s and Beyond has been organized for the Bordeaux Congress.

\section{The Pamphlet Series}

The Pamphlet Series will continue. The pamphlets are concise descriptions of selected topics produced in a form suitable for teachers. The Chairmen of this Series are $\mathrm{H}$. Schenk and J. P. Glusker. Polycrystal Book Service, Dayton, Ohio, USA, will distribute the pamphlets when they are published. A list of possible subjects has been prepared and is being evaluated.

\section{Resources for teachers}

Several aspects of teaching and presenting teaching materials have been debated by the Commission. A formal request to the $\mathrm{IUCr}$ has been made to include the 17 plane groups in the next Teaching Edition of Volume A of International Tables for Crystallography. The possibility of preparing slides for teaching purposes is being considered, and the feasibility of using the video tapes from various countries around the world is being investigated by $\mathrm{H}$. von Philipsborn. Video tapes present difficulties because of their different specifications in different parts of the world.

6. Uses of historical material in teaching

Items of historical interest add to the interest in teaching certain aspects of crystallography. J. Lima-de-Faria raised the question of starting a collection of material on the history of crystallography and also preparing a catalogue that lists where other collections of such material can be found. This idea is being investigated by a sub-committee of the Commission chaired by A. Mackay. The Historical Atlas of Crystallography, edited by J. Lima-de-Faria, is being published by the IUCr, through Kluwer Academic Publishers, Dordrecht, The Netherlands.

23 April 1990

J. P. Glusker, Chairman

\section{Commission on Electron Diffraction}

The main project of the Commission, arising from discussions at the meeting of the Commission during the Perth Congress, has been the organization of a multi-author book, Electron Diffraction Techniques, to be published in the IUCr/Oxford University Press series: IUCr Monographs on Crystallography. After preliminary discussion to establish the need for such a book, the project was initiated with J. M. Cowley as Editor. The timetable established called for camera-ready copy to be supplied by the chapter authors by December 1989 and a publication date in mid-1990. The authors selected included Commission members and other scientists prominent in the work on particular aspects of electron diffraction. The emphasis of the book is to be on the experimental and interpretive techniques for highenergy electron diffraction from solids in transmission, convergent-beam and reflection modes with some mention of gas diffraction. The project has been delayed by the tardiness of a few authors but a publication date in 1990 may still be possible.

A further suggestion made at the Perth Congress was for a survey of the computer programs now employed for the dynamical electron diffraction calculations used for the simulation of the images of crystal structures and their defects, obtained using high-resolution electron microscopy, and of the many-beam electron diffraction patterns obtained from thin crystals. The coordinator for this project is D. van Dyck, who has formulated a survey document which will be distributed in the near future. Publication of the results of the survey is planned.

Members of the Commission and other electron diffraction experts have been active in advising the Editors of Volumes B and C of International Tables for Crystallography and in contributing the sections or subsections of these volumes relating to electron diffraction. The Commission is assisting further with the proofing and the providing of critical comments on the submitted manuscripts.

The Commission's proposals for topics for an Open Commission Meeting and a microsymposium at the Bordeaux Congress were accepted, with the result that there will be sessions there of great value for the electron diffraction community, namely an Open Commission Meeting on Convergent Beam Electron Diffraction and a microsymposium on Surface Structure by Electron Diffraction and Other Methods. 
In accordance with the recommendation of the IUCr Executive Committee made at the time of the Perth General Assembly, the number of members of the Commission will be reduced from ten to eight at Bordeaux, with a probable increase in the number of consultants, including one in the area of electron diffraction studies of biological materials.

22 March 1990

J. M. COWLEY, Chairman

\section{Commission on Neutron Diffraction}

At the Perth General Assembly, the IUCr Executive Committee requested the Commissions on Neutron Diffraction and on Crystallographic Apparatus to appoint a subcommittee of four, two from each Commission, to coordinate activities of their Commissions with the synchrotron community whenever possible, and to make recommendations to the Executive Committee on the desirability of establishing a Commission on Synchrotron Radiation. The two members appointed from the Commission on Neutron Diffraction were D. E. Cox and G. Lander. Although the sub-committee Chairman failed to report to the Executive Committee, the above-mentioned two members, after discussions with members of the Commission and other members of the neutron and synchrotron community, recommended that a separate Commission on Synchrotron Radiation be established. This was done by the Executive Committee on an ad interim basis until the Bordeaux General Assembly.

Two summer schools on neutron scattering were held in 1988; in June at Chalk River, Canada, and in September at Oxford, England. Both were well attended and attracted students from numerous countries. A brief summary of the schools' activities was reported in the Commission's Newsletter in late 1988.

That neutron scattering is alive and well was exemplified by the high attendance at the Neutron Scattering Conference in Grenoble in July 1988; approximately 450 scientists participated in a very active programme.

Two neutron scattering newsletters were published by the Commission in 1988. The first, edited by B. M. Powell, was devoted to 'The Industrial Applications of Neutron Diffraction'. The second, edited by S. A. Mason, was devoted mostly to the new instrumentation upgrades at the Institut Laue-Langevin, Grenoble, France. There was a request to Gordon and Breach from some members of the neutron scattering community to consider publishing a newsletter about neutron scattering centres and activities, similar to the widely received Synchrotron Radiation News. Initially there was some concern among Commission members and the IUCr Executive Committee about making the mailing list available to Gordon and Breach and about the right of the Commission to resume publication of the newsletter if it was discontinued by Gordon and Breach. After suitable safeguards had been agreed, Gordon and Breach were given permission by the IUCr to use the Commission's mailing list in their publication of a newsletter, Neutron News, to be mailed to a very large audience, about 6000 people compared with mailings to 800 for the previous newsletters. Registered users will receive copies free of charge, similar to the arrangement whereby synchrotron users receive Synchrotron Radiation News free. The first issue of Neutron News was mailed in early March 1990 and the second issue went to press later that month.
The Commission supported and helped organize a microsymposium at the Bordeaux Congress on Dynamical Aspects of Neutron Scattering. Another microsymposium, on Neutron Diffraction in Materials Science Research, was organized by other members of the neutron community. The Commission also gave its support to two satellite meetings of the Congress; one in Paris beforehand, on Short Range Order in Ill-Ordered Materials, and one in L'Alpe d'Huez, near Grenoble, afterwards, on Complementary Applications of Diffraction by Neutrons and by X-ray Synchrotron Radiation.

23 March 1990

H. G. SMITH, Chairman

\section{Commission on Powder Diffraction}

The Commission on Powder Diffraction was established in 1987 by the Perth General Assembly. At its meetings in Perth immediately following its establishment, the Commission determined to give first consideration to seven tasks:

(1) Production and distribution of a biannual newsletter.

(2) Production of an International Workshop on the Rietveld Method.

(3) Development of a new book, or books; the first perhaps being based on the Rietveld workshop.

(4) Organizing and managing a round-robin on the Rietveld method.

(5) Establishment of an exchange 'bank' for computer programs for analyses, of all kinds, of powder diffraction data.

(6) Organization of a satellite meeting on Powder Diffraction in connection with the Bordeaux Congress in 1990.

(7) Promotion of sessions on powder diffraction at the Bordeaux Congress.

All of these seven tasks plus one other have been established, completed, or initiated, as appropriate to the nature and timeframe of the task. Four newsletters have now appeared, each edited by a different member of the Commission. More than 3500 copies of the first were distributed, partly with the help of national crystallographic societies who sent it to their general membership. A better-targeted mailing list of about 1500 persons has now been developed.

An International Workshop on the Rietveld Method was held with IUCr sponsorship, 13-15 June 1989, at the ECN in Petten, The Netherlands. There were about 150 participants, a number very much at the upper limit of what the planners had felt was desirable. It was at the ECN that Rietveld wrote the seminal programs and papers (in 1967 and 1969) which have caused his name to be attached to the method. He is still there, though no longer working very much in diffraction, and was a very prominant and much appreciated participant in the meeting and its organization. The ECN took care of all financial aspects of the meeting except the IUCr grants to young scientists. Fifteen grants totalling US $\$ 5055$ were approved but two persons were not able to come because of illness or adminstrative problems. The workshop was very successful. A book tentatively entitled The Rietveld Method, based on the 18 invited talks at the workshop, is in the scientific editing process. It will be published in the IUCr/Oxford University Press series: IUCr Monographs on Crystallography. 
The round-robin on the Rietveld refinement method is under way. Preliminary results should be reported at the Congress satellite meeting on Powder Diffraction in Toulouse, 16-19 July 1990. Each participant has received samples of two materials, one simple and one moderately complicated, from which to collect X-ray or neutron powder data and to refine the structure with the usually used local programs. Each has also received a copy of an X-ray data set and a neutron data set on lead sulfate from which the structure is to be refined with the local usually used program. All of the new data sets will then be used for structure refinement by the Commission with a single program. R. J. Hill is directing this large task.

As discussions about a program exchange bank proceeded within the Commission after the Perth meeting, it was realized that the Commission's role should be that of exchanging information about the capabilities and availability of the various programs but not the programs themselves. Accordingly, a Program Information Exchange 'Bank' has been established. It is an extension of work begun for other reasons by D. K. Smith, who was appointed as a Consultant to the Commission with the task of further developing and operating the 'Bank' for the Commission.

The satellite meeting at the Bordeaux Congress is being organized by J. Galy and D. Louër. Dr Louër is a Consultant to the Commission. An excellent programme and attendance are expected. IUCr direct sponsorship consists of some IUCr grants to young scientists and some 'start-up' funds to be repaid at the end of the financially successful meeting. However, the fund-raising efforts of Dr Galy and Dr Louer are so successful that these funds may not be needed.

The Commission has played a role in the specification of two microsymposia at the Bordeaux Congress and in the development of the second of them. They are Advances in Structure Determination from Powder Diffraction Data and Powder Diffraction Studies of Fibrous, Polymeric, and Similarly Imperfectly Ordered Materials.

In addition to the above tasks, foreseen at Perth, the Commission obtained IUCr sponsorship for the Rietveld Summer School for Beginners, which it will hold 9-11 August 1990, Cieszyn, Poland, at the site of the 14th Applied Crystallography Conference. Attendance is limited to 50 persons, so that everyone has hands-on-experience in running a simple Rietveld refinement problem on a personal computer. There are only four lecturers. IUCr sponsorship consists of IUCr grants for young scientists and some travel expenses within Europe for the lecturers.

The Commission was fortunate in having a three-part face-to-face meeting involving all members, a Consultant and the JCPDS representative in June 1989 in The Netherlands before and after the workshop. Because almost all of the participants at these meetings were also attending the workshop, the extra costs to be covered from Commission funds were very modest.
19 March 1990
R. A. YOUNG, Chairman

\section{Commission on Small Molecules}

In the second triennium of its existence the Commission has continued to foster the participation of crystallographers in interdisciplinary events such as international symposia. These activities have been described in the Annual Reports for 1987,1988 and 1989.
The efforts of the Commission to arrange for the collection of single-crystal X-ray diffraction data for colleagues without direct access to a diffractometer continue to be a success. A number of joint publications has resulted and some long-range collaborations are emerging.

One of the reasons for establishing the Commission was the concern that small-molecule crystallography, especially in the fields of inorganic and organic chemistry, was being relegated to a service function. In an effort to counter this trend, the Commission stresses the importance of interactions between crystallographers, spectroscopists and theoreticians to provide comprehensive structural studies designed to establish correlation between structure and chemical, physical and biological properties of 'molecular systems'. The Commission's suggestions for the scientific programme of the Bordeaux Congress reflect these efforts.

The Commission is concerned about the commercialization of crystallographic software and databases especially when access to not-for-profit organizations (e.g. universities and research institutes) is threatened either because of cost or contractual problems. The Commission has sought help from the IUCr, through its Executive Committee, to find solutions to such problems that are acceptable to the distributors and users alike.

Where possible the Commission has organized one-day workshops or tutorials on topics of current interest prior to the European Crystallographic Meetings. In addition to being informative, they also offer young scientists an opportunity to give short oral presentations relevant to the topic.

The Commission publishes a newsletter to inform the community of past and future events relevant to smallmolecule crystallography. The newsletter is published and distributed with the understanding that it will be circulated further by recipients.

4 April 1990

J. J. Stezowsk I, Chairman W. L. DuAX, Secretary

Ad interim Commission on Modulated Structures, Polytypes and Quasi-crystals

No report has been received from the Commission Chairman (D. Gratias).

\section{Ad interim Commission on Synchrotron Radiation}

At its meeting in July 1989, the IUCr Executive Committee decided to set up this Commission ad interim until the Bordeaux General Assembly. It invited J. R. Helliwell to serve as Chairman, and he readily accepted. A draft set of terms of reference was drawn up by him, after wide consultation with members of the relevant scientific community, and was then approved by the Executive Committee. The agreed draft terms are being published in a variety of crystallographic newsletters. The goals of the Commission, briefly, are to provide a focus of organization and information for various aspects of diffraction experiments at synchrotron-radiation sources worldwide, and so facilitate access to appropriate instruments, to maintain and improve standards and to organize meetings.

Proposals for the membership of the commission were made and were accepted by the Executive Committee. All the proposed members agreed to serve on the ad interim Commission, which has now started its work.

16 February $1990 \quad$ J. R. Helliwell, Chairman 
Appendix E: Working Party on Crystallographic Information

Membership: E. N. Maslen (Chairman), F. H. Allen, G. Bergerhoff, C. E. Bugg, M. H. Dacombe, G. Ferguson, S. R. Hall, T. F. Koetzle, C. K. Prout, M. Schlenker.

\section{Introduction}

At the Perth General Assembly in 1987 there were discussions about the impact of new means of accumulating, checking, transmitting and storing data and information on the publishing activities of the IUCr. The Executive Committee was asked to report to the Bordeaux General Assembly on the desirability of creating a Commission on Crystallographic Information to replace the present Commissions on Journals, on Structure Reports and on Crystallographic Data. The Executive Committee decided to handle this task by setting up a Working Party on Crystallographic Information.

The Working Party's first task was to assess the effect of technological changes in information processing on the IUCr's publications and on the support which it provides to crystallographic databases. Far-reaching changes must be expected, but it is logistically impossible to adapt to all the new developments simultaneously. It is important to identify the relative priority of the changes which are necessary, especially as some of these require extensive preparation.

At a meeting held in Vienna, Austria, in August 1988, the Working Party assigned top priority to establishing a powerful but flexible standard for the archiving and transmission of crystallographic information. The proposed standard file prepared by F. H. Allen, I. D. Brown and S. R. Hall (Chairman) required some new techniques for information handling. The new ideas have general applications, and it became advisable to seek software protection of the IUCr's right to unhindered use of these ideas in future. This resulted in a short delay before details of the file structure could be published. Details have been released so far only to IUCr Committees and Commissions and a few individuals, and always on a confidential basis. However, full details will be available in time for the Bordeaux General Assembly and Congress.

A high-priority task was to link the IUCr publishing activities at Chester to the global e-mail network, ideally via the JANET network for academic users in the UK. Such permission was obtained after delicate negotiations for the IUCr by R. Diamond. This e-mail link will become the gateway to a more powerful system for computer-aided IUCr publication, based on graphics workstations, to be installed shortly. These activities represent the start of a new era in IUCr publishing, and plans will be considered by the Commissions on Crystallographic Data and on Journals at Bordeaux.

\section{Progress to date}

The Working Party's activities can be described succinctly by relating them to the recommendations in its reports. Recommendation 1 . That the Chester office have a direct link to the UK academic network JANET, and be provided with full e-mail facilities.

Action: Agreement in principle having been secured, costs have been determined and the link will be established shortly.
Recommendation 2. That a standard file suitable for archiving and transmission of crystallographic data be developed. Action: The detailed proposal will be submitted to the Bordeaux General Assembly.

Recommendation 3. That improved hardware, textprocessing software and graphics facilities be installed at Chester.

Action: Costs have been determined, considered by the Finance Committee and approved by the Executive Committee.

Recommendation 4. That electronic submission of Acta Cryst. Section C manuscripts be encouraged.

Action: Referred to the Commission on Journals.

Recommendation 5. That Acta Cryst. Section C manuscripts be submitted to the Chester office for checking before undergoing the editing and refereeing processes.

Action: Referred to the Commission on Journals.

Recommendation 6. That electronic submission of the crystallographic data related to crystal structure analyses should be encouraged.

Action: Referred to the Commissions on Journals and on Crystallographic Data.

Recommendation 7. That floppy disk and printed information be allowed (though less strongly preferred) alternatives to electronic submission of Acta Cryst. Section C manuscripts.

Action: Agreed in principle and incorporated in planned purchases of equipment and software.

Recommendation 8. That structure-factor data for smallmolecule structures and lattice structures should normally be archived by the authors of Acta Cryst. Section C papers, but that the archive should also be provided by the authors for retention at Chester, if so requested by the authors, editors or referees.

Action: Referred to the relevant Commissions and to the Executive Committee for attention.

Recommendation 9. That PostScript be adopted as the standard language for communication with word processors and electronic devices.

Action: Approved in principle and incorporated in planning the purchase of computing equipment and software.

\section{Future action}

Because new technological advances have so many potential applications in the IUCr's activities, only the most urgent can be studied thoroughly in the initial stages. The further changes which are desirable should follow behind tasks of higher priority. Recommendations on which progress is less advanced are:

Recommendation 10. That manuscript submission guidelines be prepared for authors wishing to use electronic means for manuscript submission.

Comment: Implementation is expected to follow after the Bordeaux General Assembly.

Recommendation 11. That the IUCr offer to all crystallographic databases a service which would provide all or part of the archived data, and that this be transmitted electronically to the database centres at regular intervals.

Comment: Although reducing the costs of providing checked information to databases is an important objective, this will be possible only when the new computing facilities at Chester are operational. 
Recommendation 12. That the IUCr offer to other journals publishing crystallographic data a service for receiving and transmitting data in the standard file format.

Comment: This is envisaged as being a later stage in development beyond that recognized in Recommendation 11.

Recommendation 13. That the World Directory of Crystallographers be established as a database.

Comment: Collection of data for the Eighth Edition of the World Directory was in progress when this idea emerged. Although the data format as set out originally imposed some limitations, a rudimentary DBASEIII database has been prepared and sent to Chester for testing. The experience gained will be valuable for planning the future of the World Directory.

Recommendation 14. That the roles of Structure Reports, IUCr journals and handbooks be re-examined in the light of new developments in electronic archiving and publication.

Comment: Decisions on this matter will be made at the appropriate time, as the IUCr gains more experience.

\section{Conclusion}

What has emerged is that the technological developments, with their high potential for scientific publication, present a new challenge, making this an exciting time in the IUCr's history. It is also obvious that many other organizations are facing similar challenges. The IUCr's future will be affected significantly by the success or failure of the reorganization which is now in progress.

It is unlikely that the present structure of the IUCr Commissions is optimal for future activities. However, given the goodwill of those affected, reorganization of Commission structure is less urgent than the immediate technical challenges, and is envisaged as occurring in the next triennium.

Finally, I must note that this brief report merely hints at a large amount of dedicated work by a number of those involved, especially the group responsible for the archive file (Frank Allen, David Brown and Syd Hall), Bob Diamond on e-mail, and a University of Western Australia computing science student (Mike Kennett) on the World Directory database.

10 April 1990

E. N. Maslen, Chairman

Appendix F: Reports of the representatives on Scientific and Regional Associates

\section{Asian Crystallographic Association (AsCA)}

The Asian Crystallographic Association (AsCA) was constituted during the Perth Congress in 1987 and was accepted as a Regional Associate of the IUCr at the Perth General Assembly. An IUCr representative to AsCA was then appointed. The objectives of the Association are to promote and coordinate crystallographic research and teaching in the Asian region. AsCA is composed of the following member countries and regions: Australia, People's Republic of China, Hong Kong, India, Japan, Korea, Malaysia, New Zealand, Pakistan, Philippines, Sri Lanka, Taiwan and Thailand.

The AsCA Council representatives for 1988-1990 are P. M. Colman, G. J. Gainsford, R. P. Gunawardane, S. R.
Hall, A.-U. Haq, J. Harada, S. Hoshino, T. F. Lai, K. Lal, F.-m. Miao, A. H. Othman, Y. J. Park, W. Patalinghug, P. Phavanantha, M. A. Viswamitra, Y. Wang. The elected Executive is S. R. Hall (President), M. A. Viswamitra (VicePresident) and J. Harada (Secretary-Treasurer).

The principal function of AsCA in its first triennium has been to disseminate information about crystallographic activities in the region and in a number of interested societies. This was done mainly through AsCA Newsletters which were distributed to all member countries. These each contained details of meetings and research activities in the area over a six-month period, and a summary of crystallographic news from North America and Europe. For many members of AsCA, especially those in countries without national societies, these newsletters represent an important source of general crystallographic news.

In the future, it is expected that AsCA will play a more prominent role in the organization and the sponsorship of schools and workshops in the region and, ultimately, will be in a position to organize conferences of its own. Initially this will probably be done in conjunction with one of the regular national meetings in the region.
6 April 1990
S. R. HAll, AsCA President

\section{European Crystallographic Committee (ECC)}

The IUCr representative attended the meetings of the European Crystallographic Committee held on 17 August 1987 during the Perth Congress, on 31 August 1988 during ECM-11 in Vienna, Austria, and on 22 August 1989 during ECM-12 in Moscow, USSR. During these meetings the representative participated in the discussions of various topics, e.g. in Perth it was agreed to suggest to the ECM organizers that the registration fee should be limited to one-fifth of the unit contribution to the IUCr (at present SwFr 890). The representative also intermediated between the Organizing Committee of ECM-11 and the IUCr Executive Committee, to ease the troubles generated by the financial limits of sponsorship applied for by an exceptionally large number (about 40) of young scientists from Eastern Europe.

During the meeting at ECM-11 in Vienna, the organization of ECM-12 was examined and proposals to hold ECM-13 in Ljubljana, Yugoslavia, in August 1991 and ECM-14 in Twente, The Netherlands, in 1992 were accepted. The invitation to meet in the German Democratic Republic in 1994 was accepted, there being no ECM in 1993 as this is an IUCr Congress year. In the course of the Moscow meeting, the President of the IUCr met the delegates and briefed them personally about the delicate problems which had occurred previously in connection with the location of the XVI IUCr Congress in 1993.

The present officers of the ECC are as follows: President, G. S. D. King (Belgium); Vice-President, K. Huml (Czechoslovakia); Secretary, G. Filippini (Italy). New officers will be elected at the meeting of the ECC which will be held during the Bordeaux Congress.
20 March, 1990
A. KÁlmáN, Representative

\section{International Organization of Crystal Growth (IOCG)}

The main activities of the IOCG during the triennium are, according to its Statutes, the organization of an international conference and an international summer school 
on crystal growth, usually referred to as ICCG and ISSCG respectively. Both events are intended to be plenary in character and to cover all relevant aspects of the crystal growth area, such as technology, theory, application, characterization etc.

In this triennium both events (ICCG-9) and ISSCG-7) were hosted in Japan by the Japanese Association for Crystal Growth. ICCG-9 was held in Sendai, 20-25 August 1989. There were over 1000 participants and the conference, which was structured into symposia and general sessions, consisted of 5 plenary papers, 79 invited papers and 740 contributed papers. When compared with the total numbers of papers presented at the previous three ICCGs $(600,400$, 500 approximately), the 840 papers presented at ICCG-9 reffect the remarkable expansion of research activities and interests in the field. The proceedings of ICCG-9 will be published in 1990 as a single issue of $J$. Cryst. Growth. ISSCG-7, held in Zao, 26-31 August 1989, had about 120 participants. The school provided a high-level programme of lectures that covered a wide range of topics. Unfortunately, because Japan does not adhere to the ICSU principles on the free circulation of bona fide scientists, sponsorship could not be given.

During the IOCG General Assembly, which took place during ICCG-9, the composition of the new IOCG Executive Council was approved for the triennium 1989-92. Its membership is now as follows: President, B. Cockayne (UK): Vice-President, A. A. Chernov (USSR); Vice-President, R. F. Sekerka (USA); Secretary, M. Schieber (Israel); Treasurer, E. Kaldis (Switzerland); Past President, R. Kern (France); Full Members, K. W. Benz (FRG), R. Feigelson (USA), D. T. J. Hurle (UK), H. Komatsu (Japan); ex officio members, J. Sunagawa (Japan), W. Bonner (USA), R. A. Laudise (USA), C. Paorici (Italy); V. V. Osiko (USSR).

20 March 1990

C. PAORICI, Representative

Joint Committee on Powder Diffraction Standards - International Centre for Diffraction Data (JCPDS-ICDD)

The IUCr representative attended several of the semiannual meetings of the JCPDS-ICDD during the triennium. It is a not-for-profit organization. Its purpose can be described as to gather, cull, edit and disseminate useful diffraction data, mostly powder data useful for crystalline phase identification, in the international arena. It is a substantial organization with a paid staff of more than 20 persons under the direction of a General Manager, its own building in Swarthmore, Pennsylvania, USA, and 114 volunteer members in more than ten countries. It is governed by a non-staff Board of Directors chaired, during this triennium, by D. K. Smith. A great amount of the work of acquiring new or improved powder diffraction patterns, setting policy and new directions, generating new ideas for services and testing out new products and ideas is done by volunteers organized into committees, subcommittees and task groups.

The JCPDS-ICDD operates a very substantial Grants-inAid programme which directly generates powder diffraction patterns deemed desirable but which are not otherwise available. During 1988, 37 such grants totalling US $\$ 360000$ were funded. Two-thirds of them were for work outside the USA. There are four types of grants. For more information about the programme and how to apply for a grant, write to Mr J. Messick, General Manager, JCPDS-ICDD, 1601
Park Lane, Swarthmore, PA 19081, USA. There is a constant emphasis on improvement of pattern quality, and of searchmatch and other retrieval techniques, on expansion of the data file both in numbers and kinds of patterns (e.g. digitized data, electron diffraction data) and in the kind of additional physical and chemical data encoded with the diffraction data. The advent of the CD-ROM medium for data storage and retrieval is having a profound positive influence.

The JCPDS-ICDD holds several workshops each year and co-sponsors various diffraction meetings, including the forthcoming Symposium on Powder Diffraction to be held 16-19 July 1990 in Toulouse as a satellite meeting of the Bordeaux Congress. It continues to stress its international character and to stress an international presence. More than half its revenue comes from outside the USA. It publishes the journal Powder Diffraction, whose editors, together with the editors of the Journal of Applied Crystallography, attempt to exchange or transfer manuscripts submitted to one journal which might better belong in the other. In so far as the IUCr representative has determined, this cooperation is working well.

20 April 1990

R. A. YOUNG, Representative

\section{Appendix G: Reports of the representatives on bodies not belonging to the Union}

IUPAP Commission on the Structure and Dynamics of Condensed Matter

The main activity of this Commission is to give preliminary examination to applications for sponsorship by IUPAP of conferences within its field of interest and to make appropriate recommendations to IUPAP. The work is done by correspondence. For the period under review, there are no remarkable actions to be reported.

28 March 1990

A. KALMAN, Representative

Action Committee on Conferences and the Condensed Matter Division of the European Physical Society

The meeting of the Committee on Conference in May 1987 was attended by the then IUCr representative, M. Nardelli. Reports were given on the 7th European Physical Society (EPS) General Conference, held in Helsinki in 1987, and on preparations for the 8th EPS General Conference to be held in Amsterdam in 1990. The general guidelines for EPS Divisional Conferences were considered and approved, as were guidelines for preparing and presenting talks at scientific meetings. Although there were some discussions of visa problems, it was decided to take no action. At the next meeting, in March 1988, members expressed concern at the low impact of the EPS on industry, and the wide disparity between research and industry. They considered the long list of meetings seeking EPS sponsorship, and noted with regret the proliferation of overlapping meetings. No good solution could be suggested, however. The Committee gave approval or sponsorship to about 90 EPS meetings. In March 1989, the Committee discussed the refereeing system in connection with the handling of confernce proposals. The main questions were (1) should referees also look into the selection of invited speakers and their geographical distribution, and (2) could it be tolerated that, in certain conferences, the same people rotate in the International Programme Committee? About 70 EPS meetings received approval or sponsorship. 
At a special meeting in November 1989, the EPS President summarized recent decisions of the council. The former Advisory Committees had been renamed Action Committees. The newly named Action Committee on Conferences would aim to coordinate the works of other committees, divisions and national societies via a 'task force' of four or five people. The Committee also considered how to organize study conferences in physics and in other domains, similar to the Gordon Conferences in the USA, perhaps under the appealing name of Fermi Conferences.

The former IUCr representative, while attending the 1986 meeting of the Condensed Matter Division (CMD) of the EPS, established direct contacts with this Division, which has common interests with the IUCr on various topics. Consequently, the IUCr representative on the EPS Action Committee on Conferences has been invited regularly to the meetings of the CMD board, in December 1987, April 1988, December 1988 and December 1989. He will also attend the next meeting, in Lisbon, Portugal, on 9 April 1990. At these meetings he repeatedly drew the Division's attention to the activities of those IUCr Commissions of particular relevance to the Division, and requested all members to inform the IUCr Executive Secretary of meetings for announcement in the Forthcoming Meetings section of the Journal of Applied Crystallography. During the December 1989 meeting, the IUCr representative suggested cooperation between the ad interim Commission on Synchrotron Radiation of the IUCr and the corresponding, recently created, Interdivisional Group of the EPS. M. Colapietro acts for both communities. The CMD organizes annual conferences, which include topics close to crystallography. In addition to the unavoidable financial problems, standard items on the agendas include the selection of topics, invited speakers and the members of the international programme committees. It is worth noting that the CMD has continuously been amending its list of Who's Who in Condensed Matter Physics in Europe, which is also available on floppy disk.

\section{March $1990 \quad$ A. KÁLMÁN, Representative}

IUPAC Interdivisional Committtee on Nomenclature and Symbols (IDCNS)

The IDCNS is the central organization that reviews all relevant recommendations originating within IUPAC Commissions and Divisions for publication in Pure \& Applied Chemistry. Typically, the IDCNS reviews about 50 such documents each year and a copy of each is received by the IUCr representative for comment. An important principle used by the IDCNS is that no rule in science should be regarded as sacrosanct, and that those who draft new recommendations are free to transgress any rule if two conditions are met: (1) they must be aware of the former rule and quote it, and (2) full rationale must be given for the new or modified proposed rule or usage. The IDCNS meets on alternate years in association with IUPAC General Assemblies, and in the UK on the other years. The IUCr representative or his alternate (A. J. C. Wilson) partiejpates at the meeting location that results in the greatest economy for the IUCr. The 1987 meeting colacided the XIV IUCr Congress, and the IUCr could not be tepresented The alternate took part in the meeting held in $0 \times$ ford, 9-10 September 1988, and the representative in that held in Lund,
8-9 August 1989. The IDCNS provides a valuable platform for viewing the complex interactions between major international bodies charged with standardizing the names and values of important quantities, in addition to the other intrinsic advantages it offers the IUCr. Among the most influential international nomenclature bodies is the Comité Consultatif des Unités du Conférence Générale des Poids et Mesures. IUCr representation on this committee may be advantageous.

13 March 1990

S. C. Abrahams, Representative

International Council for Scientific and Technical Information (ICSTI)

The triennium 1985-1986 saw major changes: a constitutional reorganization whereby the Abstracting Board of the International Council of Scientific Unions (ICSU AB) became the International Council for Scientific and Technical Information (ICSTI), and a resumption of a substantial technical programme by ICSTI. This report, for the triennium 1987-1989, focuses mainly on those aspects of the technical programme that appear to be of greatest interest to the IUCr.

Numeric Data Group. The Numeric Data Group was organized in 1986, and several possible activities were discussed at the annual meeting in 1987 . The one that has made the greatest visible progress is the compilation of a directory of numeric databases, based on questionnaires sent to compilers and distributors of databases; the addresses of the organizations to be questioned were compiled by experts in the various fields of science. There was a high proportion of responses, and the directory is now (February 1990) in complete draft. Unfortunately it has been put together in a mechanical fashion, with the result that the same database may appear several times. These duplications are in the course of being weeded out, and it is hoped that it can be published about the end of 1990 . A second major activity of the group has been a study of user-friendly software. This also may lead to a publication fairly soon.

Group on Education and User Needs. The Group on Education and User Needs started the triennium badly, largely because in 1987 it was scheduled at the same time as sessions on Economic Issues and on Legal Aspects of Information Transfer, which many members of ICSTI naturally regarded as of more immediate importance. However, such competition was avoided in 1988, when R. Hsieh described its education programme and A. J. C. Wilson described that of the IUCr. A written report on 'Education and Training for Database Use in Japan' by $\mathrm{K}$. Kawano was considered at the same time. As a result of the discussion in 1988, R. Hsieh and M. Day proposed a study to determine the nature, size, scope, content and results of ongoing programs for (1) training scientists and engineers in the use of computerized information and data services and products, and (ii) developing simplified userfriendly search software specially designed for scientists and engineers. The proposal was accepted in 1989 and the study is in progress. At this request, Executive Board relieved A J.C. Wilson of his penondity as Chairman of this Group; and appointed R. Hich his thecessor.

Working Group in Chemistry. One of the concomitants of the reorganization of ICSU AB into ICSTI has been a change in the purpose of the Groups. Originally these had 
been concerned with subject fields (Physics, Chemistry, Biology etc.), but now most are concerned with the general problems (Economic Issues, Legal Aspects, Primary/ Secondary Relations etc.). The Working Group in Chemistry is the only survivor of the traditional type. In the first two years of the triennium it was largely occupied with unspectacular nomenclature problems, but in 1989 it embarked on a more ambitious activity. G. Poetzscher had prepared a memorandum for the Group on 'User Needs in Chemical Information'. It was felt to be useful but in need of much revision and rewriting before it could be presented to a wider audience; suggestions were received from several ICSTI members. A. J. C. Wilson agreed to undertake the rewriting, and the revised paper has been submitted to the Journal of Chemical Information and Computer Science. A shortened version will be presented at the International Symposium on The Future of Scientific, Technological and Industrial Information Services to be held in Leningrad in May 1990.

Technical sessions. One or more technical sessions are ordinarily organized at the annual meeting of ICSTI; in 1987 a technical session was organized by the Numeric Data Group. At the 1989 meeting there was a technical session on Bibliometric Techniques and New Added-Value Products. Bibliometric techniques provide a method for comparing the 'productivity' of individuals, laboratories or countries, and there was a lively interest in the six talks. Most of such work is based on the Science Citation Index, and thus publications in journals not covered by the SCI are not represented. There was a lively criticism of the papers, of which at most two showed a full appreciation of the weaknesses as well as of the strengths of the methods. The history of ICSTI can be traced back to a meeting on scientific information organized by Unesco in 1949; the actual incorporation of ICSU AB under Belgian law took effect some years later. Though it was not exactly a technical session, it may be recorded that in 1989 there was celebration of the fortieth anniversary, with four short talks: Introduction (J. Michel, outgoing President), Forty Years of ICSU AB/ICSTI (A. J. C. Wilson), Main Technical Achievements of ICSU AB/ICSTI (M. Day) and The Future of ICSTI (E. Kennedy, incoming President). The text of A. J. C. Wilson's talk has been deposited at the IUCr office.

Finances. ICSTI and its predecessor had encountered a problem analogous to one that has troubled IUCr from time to time: most of the income was in US Dollars, most of the expenditure was in French Francs. The strength of the Dollar in previous years had enabled ICSTI to hold dues constant for four years, but its weakness in 1988 required an increase in Dollar terms; this would mean little or no increase in their own currencies for most non-US Members. After some discussion it was agreed to simplify the book-keeping by using French Francs for the main accounts, and converting only the balance sheet and summaries into Dollars. The dues were fixed in French Francs at the General Assembly in 1989: for the IUCr they now amount to FFr 3000 per year.

Membership. New members elected during the triennium include the European Patent Office (EPO), the International Group of Scientific, Technical and Medical Publishers (STM), the Institut National de la Santé et de la Recherche Medicale (INSERM) and the International Union of Pure and Applied Physics (IUPAP). Although technically a new member, IUPAP had been a member of ICSU AB, but had not agreed to automatic transfer of membership to ICSTI. J. R. Smith, for 20 years the Chairman of the Technical Advisory and Consultative Committee and its variously named predecessors, was made an Honorary Member in 1989.
13 February 1990
A. J. C. Wilson, Representative

\section{International Council of Scientific Unions (ICSU)}

The IUCr representative on ICSU is traditionally its Immediate Past President, and is a member of the ICSU General Committee which meets annually. Every alternate year these meetings are held in association with the biennial ICSU General Assemblies, which are also attended by the IUCr Executive Secretary.

ICSU has two categories of membership. There are 76 National Members, which are scientific academies or research councils. In those countries which are members of the IUCr, the National Member is usually the same as the Adhering Body to the IUCr. ICSU also has 20 International Scientific Union Members, including the IUCr. The complement of these two groups provides a wide spectrum of scientific expertise enabling members to address major international interdisciplinary issues which none of them could handle alone. In addition, ICSU has 26 Scientific Associates.

ICSU seeks to accomplish its role in a number of ways. It initiates, designs and coordinates major international interdisciplinary research programmes, such as the International Geosphere-Biosphere Programme on Global Change (IGBP), which complements the World Climate Research Programme run jointly with the World Meteorological Organization (WMO), and aims to describe and understand the interactive physical, chemical and biological aspects of the total earth system, and the International Space Year 1992. The IUCr may be able to participate in the latter programme, with respect to microgravity materials-science experiments. ICSU also creates interdisciplinary bodies which undertake activities and research programmes of interest to several member bodies. Examples of such activities include antarctic, oceanic, space and water research, problems of the environment, genetic experimentation, solar terrestrial physics and biotechnology.

In addition to these programmes and activities, several bodies set up within ICSU address matters of common concern to all scientists, such as the teaching of science, data, science and technology in developing countries, ethics and the free circulation of scientists. Finally, ICSU maintains close working relations with a number of intergovernmental and non-governmental organizations, in particular with Unesco, in cooperation with which a number of international programmes have been launched and are being run, and with WMO.

During the triennium, an ICSU General Assembly was held in 1988 in Beijing, and General Committee meetings were held in 1987 in Rome, in 1988 in Beijing in association with the above General Assembly, and in 1989 in Lisbon. Most of the ICSU activities do not concern the IUCr directly. Although ICSU places great emphasis on science in developing countries, none of their projects are relevant to crystallography. Their lectureship programme, organized jointly with the Third World Academy of Sciences in 
Trieste, is proceeding slowly, but is likely to be similar to the IUCr Visiting Professorship Programme being set up by the IUCr Commission on Crystallographic Teaching.

The problems of the free circulation of scientists led to lengthy and heated debates, but some of the important cases are still unsolved. It seems that the IUCr and IUPAC are among the strongest supporters of the free circulation principle; other scientific unions and national representatives adopt softer attitudes.

12 April 1990

TH. HAHN, Representative

\section{ICSU Committee on Data for Science and Technology (CODATA)}

During the triennium CODATA met once, in Karlsruhe, Federal Republic of Germany. The next meeting will be in Columbus, Ohio, USA in July 1990. In common with CODATA's various publications (a list of titles may be requested from the IUCr representative), topics of the conferences reflect the international activities in the collection, storage and dissemination of data in different sciences.

The IUCr seems to have the best organized method of handling its specific data. It is likely that the report at the July 1990 meeting of CODATA, on the planned reorganization of the IUCr's data activities and the results of its Working Party on Crystallographic Information, will confirm the IUCr's position as a leader in this field. Continuation of the cooperation between the IUCr and CODATA is not only worthwhile because of the IUCr's leading role in this field, but also because it increases the opportunity of bringing crystallographic results to the knowledge of the scientific community in general and the likelihood of these results being applied as much as possible in other fields.

Moreover, CODATA has its own task groups, working groups, commissions and committees with various objectives, and the IUCr could participate in some of them. These are CODATA Referral Database, Artificial Intelligence and Computer Graphics, Network Steering Committee, Fundamental Physical Constants, Materials Database Management, Hybridoma Data Bank, Biological Macromolecules, Microbial Strain Data Network, Biological Databases, Terminology and Nomenclature Used in Biology, Critically Evaluated Phase Equilibrium Data, Chemical Thermodynamic Tables, Geothermodynamic Data, Environmental Databases, Industrial Data, Multisatellite Thematic Mapping, Data Sources in Far-Eastern Countries and Systematic Identification of Foods in Numerical Data Banks. More task groups may be formed in respect of the IUCr's activities; I recommend nomination of members for the groups on CODATA Referral Database, on Artificial Intelligence and Computer Graphics and on Biological Macromolecules.

Electronic data transfer for any purpose is one of the most common problems for all branches of science. In spite of very efficient use from some places to others there also are limitations, e.g. by charges, by gateways, by lack of networks and terminals and by local difficulties. CODATA, through its Network Steering Committee and its connections with ICSU and Unesco, could stimulate improvements in this field which would benefit the IUCr as well
21 March 1990
G. BERGERHofF, Representative

ICSU Committee on Science and Technology in Developing Countries (COSTED)

This Committee was set up by ICSU in 1966 for the encouragement of science and technology in developing countries. To achieve this purpose, the Committee has the following objectives: to coordinate and encourage efforts by the International Scientific Unions to assist the developing countries; to work with the Special and Scientific Committees of ICSU in order to facilitate the greatest possible participation in their programmes by scientists in the developing countries; to foster affiliations with COSTED of national or regional committees which could identify scientific and technical problems related to developing countries and recommend programmes and other activities for COSTED; to provide liaison and advisory services, when requested, to international and regional scientific organizations; to consider the methodology of using science and technology to assist the developing countries; and to undertake other activities and programmes designed to assist developing countries through the use of science and technology.

In recent years several regional representatives have been appointed, in an attempt to improve COSTED's scope and efficiency, However, the IUCr representative has received minimal communications about COSTED activities.
12 April 1990
TH. HaHN, Representative

\section{ICSU Committee on Space Research (COSPAR)}

The main activity in this triennium has been the second Symposium on Materials Science in Space, which was held in the frame of the COSPAR 27th Plenary Meeting in Helsinki, Finland, 18-29 July 1988 (organized by the IUCr representative). The first one was held in Philadelphia, USA, in 1976, to decide if this scientific discipline should be represented in COSPAR.

The proceedings (Advances in Space, Microgravity, Vol. 8, No. 12, 1988, Pergamon Press, 330 pages) contain a selection of 33 papers from many fields of microgravity research. Unfortunately, no contributions in protein crystallography were available at the COSPAR meeting. Important results were obtained, however, a few months later. In the frame of a NASA programme, four scouting protein crystal growth shuttle flights took place between April 1985 and January 1986. They were used by the University of Alabama to develop the equipment, and the first crystal growth studies took place in September 1988 and March 1989. A great number of experiments were performed which resulted in very good crystals of, for example, $\gamma$-interferon, porcin elastase and isocitrate lyase. According to the authors, the results show larger crystals with higher-resolution diffraction data and more uniform morphologies. More data are expected in Bordeaux.

An International Space Year is planned in 1992. COSPAR is involved strongly in the organization. After discussions with the Commission on Crystal Growth and Characterization of Materials and with the Executive Committee, it was decided that the IUCr could best participate in these activities by co-sponsoring a school in a developing country in the field of materials science in space. Depending on its success, such a school could be repeated later in other parts of the third world. 
Another activity in preparation is the COSPAR 28th Plenary Meeting in The Hague, The Netherlands, 25 June-7 July 1990 . A record number of 150 submitted papers in the field of materials science in space shows the world-wide interest in this field and the establishment of COSPAR as a neutral meeting point.

17 April 1990

E. KALDIS, Representative

\section{ICSU Committee on the Teaching of Science (CTS)}

CTS met in 1987 and 1989 in Paris. Most of its activities are directed to the teaching of science in developing countries, where teaching is difficult or impossible because of a lack of instruments, and therefore the important task is the development and maintenance of low-cost equipment. The training of technicians is also an important activity of CTS. One of the future goals of CTS is to popularize the teaching of science in general. This is considered to be most important, and essential if science is to survive.

Of its other activities, those which are a follow-up of the CTS Teaching Congress in Bangalore get first priority. Microcomputers in Teaching and Research is another highpriority item, in which Unesco is also very interested. A pilot project is going on to use microcomputers for crystallographic applications. However, Unesco budgets are small and progress is therefore critically dependent on the enthusiasm of individuals. Unesco also expressed interest in university science teaching but has restricted this for the time being to the basic disciplines, such as chemistry and physics; crystallography may enter later. CTS is also setting up activities as part of the Global Change Programme of ICSU itself.

There are therefore many activities going on in ICSU CTS, most of them suffering from lack of money, but nevertheless many of them on a semi-permanent basis due to enthusiastic international cooperation. The training of technicians is an important permanent activity of CTS, as well as the teaching of science at the primary level. The latter is directed at the science and mathematics education of future elementary school teachers throughout the world.

17 April 1990

H. SCHENK, Representative

\section{Appendix H: Sponsorship of meetings: Sub-committee} on the Union Calendar

The Sub-committee on the Union Calendar is a subcommittee of the Executive Committee and, therefore, according to Statute $8 \cdot 1$, has no obligation to report to the General Assembly. However, a summary of its activities is given in this Appendix for the information of delegates.

During the period since the Perth General Assembly, the Sub-committee has considered many requests for sponsorship and financial support by the IUCr and has made recommendations accordingly to the Executive Committee. The Executive Committee's policy, of giving financial support specially devoted to help young scientists, was successfully applied. An important aspect that must be guaranteed by the organizers of all meetings sponsored by the IUCr is the free circulation of bone fide scientists.

The following meetings on topics of crystallographic significance have received IUCr sponsorship, financial support for young scientists and, often, additional finance for general organizational expenses. The $\mathrm{IUCr}$ also provided substantial financial support to the Perth Congress and the
Bordeaux Congress. The financial support given to assist young scientists totalled SwFr 35000 in 1987, SwFr 74000 in 1988 and SwFr 79000 in 1989. The support for 1990 is even larger. Hence this support has helped several hundred young scientists attend a scientific meeting during the triennium. The average level of travel assistance provided to young scientists was approximately SwFr 450 , but the amounts span a wide range ( $S w F r ~ 180$ to $S w F r$ 1500) depending on the type and location of the meeting.

Symposium on the Validity of Structures from Electron Microscopy, Melbourne, Australia, 8-9 August 1987 (satellite meeting of Perth Congress)

Symposium on Neutron Scattering, Lucas Heights, Australia, 8-10 August 1987 (satellite meeting of Perth Congress)

Symposium and Workshop on X-ray Powder Diffractomety, Perth Australia, 20-22 August 1987 (satellite meeting of Perth Congress)

International Winter School on Crystallographic Computing, Bedford Park, Australia, 22-29 August 1987 (satellite meeting of Perth Congress)

Symposium on Accuracy in Structure Factor Measurements, Lorne, Australia, 23-26 August 1987 (satellite meeting of Perth Congress)

International Conference on Applications and Techniques of Small-Angle Scattering, Argonne, Illinois, USA, 26-29 October 1987

International School on Crystal Growth and Characterization of Materials for Electronics, La Habana, Cuba, 30 November-11 December 1987

School on Crystallography of Molecular Biology, Erice, Italy, 29 May-7 June 1988

Sagamore IX Conference on Charge, Spin and Momentum Densities, Luso-Buçaco, Portugal, 26 June-2 July 1988

Second International Conference on Biophysics \& Synchrotron Radiation, Chester, England, 4-8 July 1988

Symposium on Molecular Recognition: Its Role in Chemistry and Biochemistry, Sopron, Hungary, 24-27 August 1988

Workshop: Introduction to International Tables for Crystallography, Volume A, Vienna, Austria, 26-27 August 1988

Eleventh European Crystallographic Meeting, Vienna, Austria, 28 August-2 September 1988

International Conference on Defects in Insulating Crystals, Parma, Italy, 29 August-2 September 1988

Summer School on Crystallography and its Teaching, Tianjin, People's Republic of China, 15-24 September 1988

International Summer School on Neutron Scattering, Oxford, England, 20-30 September 1988

International Symposium on Computational Methods in Chemical Design: Molecular Modelling, Theory and Experiment, Schloss Elmau, Federal Republic of Germany, 10-14 October 1988

Meeting on the Crystal Structure and Chemistry of Ribonucleases, Moscow, USSR, 28 November-2 December 1988

International Conference on the Use of X-ray Crystallography in the Design of Anti-viral Agents, Kona, Hawaii, USA, 6-8 February 1989

Symposium on Crystallographic and Modelling Methods in Molecular Design, Gulf Shores, Alabama, USA, 30 April-3 May 1989 
Meeting on Crystallography of Biological Macromolecules: Methods and Results, Como, Italy, 16-19 May 1989

Third International Meeting on Quasicrystals. Incommensurate Structures in Condensed Matter, Vista Hermosa, Mexico, 29 May-2 June 1989

International Workshop on the Rietveld Method, Petten, The Netherlands, 13-15 June 1989

Gordon Conference on Electron Distributions and Chemical Bonding, Plymouth, New Hampshire, USA, 3-7 July 1989

International Workshop on Accurate Crystal Structure Determination at High Pressure, Münich, Federal Republic of Germany, 24-25 July 1989

Symposium on Symmetry of Structure, Budapest, Hungary, 13-19 August 1989

Third International Conference on Crystallization of Biological Macromolecules, Washington, DC, USA, 13-19 August 1989

Symposium on Organic Crystal Chemistry, PoznánRydzyna, Poland, 14-17 August 1989

Twelfth European Crystallographic Meeting, Moscow, USSR, 20-29 August 1989

Ninth International Hydrogen Bond Conference, Zeist (Utrecht), The Netherlands, 10-15 September 1989

Winter School on Crystallography of Natural Materials for Science and Industry, Bangkok, Thailand, 7-15 February 1990

First International Conference on Epitaxial Crystal Growth, Budapest, Hungary, 1-7 April 1990

International School on Crystal Growth and Crystallographic Assessment of Industrial Materials, Sitges, Barcelona, Spain, 13-25 May 1990

Symposium on Short Range Order in Ill-Ordered Materials, Orsay, Near Paris, France, 16-18 July 1990 (satellite meeting of Bordeaux Congress)

Symposium on Powder Diffraction, Toulouse, France, 16-19 July 1990 (satellite meeting of Bordeaux Congress)

Symposium on Symmetry in Physical Space and in Superspaces. Physical Applications: Quasicrystals, Incommensurate Phases, Châtenay-Malabry, near Paris, France, 29-31 July 1990 (satellite meeting of Bordeaux Congress)

Symposium on Complementary Applications of Diffraction by Neutrons and by X-ray Synchrotron Radiation, near Grenoble, France, 29-31 July 1990 (satellite meeting of Bordeaux Congress)

International School on Crystallographic Computing, Bischenberg, near Strasbourg, France, 29 July-5 August 1990 (satellite meeting of Bordeaux Congress)

Summer School for Beginners with the Rietveld Method, Cieszyn, Poland, 9-11 August 1990

Iberoamerican School on Crystallography and XI Iberoamerican Congress on Crystallography, MéridaMérida, Venezuela, 30 September-13 October 1990

International Symposium on Crystallography and Molecular Biology, São Paulo, Brazil, 5-9 November 1990

Intensive Course in X-ray Structure Analysis, Aston, England, 18-24 March 1991

International Workshop on Methods of Structure Analysis of Modulated Structures and Quasi-crystals, BilbuoLekeitio, Spain, 29 April-4 May 1991
Third European Conference on Crystal Growth, Budapest, Hungary, 5-11 May 1991

International Workshop on Modern Magnetic Materials and their Technological Impact, La Habana, Cuba, 19-29 May 1991

Summer School on Neutron Scattering, Oxford, England, 18-29 September 1991

The organizers of all IUCr-sponsored meetıngs are requested to recommend the journals of the IUCr as a suitable channel of publication for the original papers presented at the meeting. 43 papers presented at the International Conference on Applications and Techniques of Small-Angle Scattering, held at Argonne, 26-29 October 1987, were published in the December 1988 of Journal of Applied Crystallography, Vol. 21, pp. 582-885. If organizers intend to publish proceedings, they should consider the IUCr Crystallographic Symposia Series, which is published jointly by the IUCr and Oxford University Press.

Organizers of meetings wishing to seek IUCr sponsorship should submit applications at least six months in advance of the date of the meeting, writing to the Chairman of the Sub-committee. The present Chairman is $P$. Coppens, Department of Chemistry, State University of New York at Buffalo, Acheson Hall, Buffalo, NY 14214, USA. Applications for sponsorship of satellite meetings must be submitted through the Chairman of the Organizing Committee of the main meeting.

\section{Appendix I: IUCr/Oxford University Press Book Series}

The launching of this Series was reported to the General Assembly at Perth. The agreement between the IUCr and the Oxford University Press (OUP) was finalized soon afterwards. The Series consists of three subseries:

IUCr Crystallographic Symposia (IUCr CS)

IUCr Monographs on Crystallography (IUCr MC)

IUCr Texts on Crystallography (IUCr TC).

The Book Series Selection Committee membership is $\mathbf{J}$. H. Robertson (UK: Chairman), A. M. Glazer (UK), J. P. Glusker (USA), K. Kuchitsu (Japan) and V. I. Simonov (USSR), with H. J. Stanbury as the ex officio representative of the OUP and the President and the General Secretary of the IUCr as ex officio members. This Committee considers proposals for new publications, whether proceedings of schools or symposia, monographs or textbooks on crystallography, and makes recommendations to the IUCr Executive Committee and to the Delegates of the Press (the body responsible for approving all publications handled by the OUP).

\section{Books already published}

IUCr CS-1. Glusker, J. P., Patterson, B. K. \& Rossi, M. (Eds.) 1987. Patterson and Pattersons. Fifty Years of the Patterson Function. (Proceedings of the symposium of that title held in Philadelphia, Pennyslvania, USA, in November 1984.) Sales to date: $\sim 700$ copies.

IUCr CS-2. Stezowski, J. J., Huang, J.-1. \& Shao, M.-c. (Eds.) 1988. Molecular Structure. Chemical Reactivity and Biological Activity. (Proceedings of the symposium of that title held in Beijing, China, in September 1986.) Sales to date: $\sim 500$ copies. 
IUCr CS-3. Isaacs, N. W. \& Taylor, M. R. (eds.) 1988. Crystallographic Computing 4. Techniques and New Technologies. (Proceedings of the International School held in Adelaide, Australia, in August 1987.) Sales to date: $\sim 500$ copies.

IUCr TC-1. Guinier, A. \& Jullien, R. 1989. The Solid State. From Superconductors to Superalloys. (Translation, by W. J. Duffin, of the original French, La Matiere à l'Etat Solide - des Supraconducteurs aux Superalliages.) Sales to date: $\sim 1700$ copies paperback, $\sim 300$ copies hardback.

\section{Books soon to be published}

IUCr MC-1. Domenicano, A. \& Hargittai, I. (Eds.) Accurate Molecular Structures. (Work on this project started over three years ago, before the Book Series Committee was set up.) The typescript is virtually completed now; 18 out of 21 chapters were already in final form in October 1989. Publication should be possible very soon.

IUCr MC-2. Cowley, J. M. (Ed.) Electron Diffraction Techniques. Final drafts of the 14 chapters of this monograph were expected to be complete at the end of 1989 , with publication early in 1990.

IUCr MC-3. Young, R. A. (Ed.) The Rietveld Method. Monograph based on invited papers at the International Workshop held in Petten, The Netherlands, in June 1989.

IUCr MC-4. Cruickshank, D. W. J., Kato, N. \& Juretschke, H. J. (Eds.) Paul Peter Ewald - a Memorial Volume. This monograph has grown out of the commemorative microsymposium held during the Perth Congress. The manuscripts are currently in their near-final stages.

IUCr CS-4. Jones, D. W., Kałuski, Z. \& Garbarczyk, J. (Eds.) Organic Crystal Chemistry. Proceedings of the Symposium of August 1989 (the seventh of its kind) held in Poznań-Rydzyna, Poland. Work on the manuscripts is still at an early stage. This proposal has not yet (as at April 1990) received the necessary approval from the OUP.

IUCr TC-2. Paufler, P. Physical Crystallography. This will be the second edition (revised and extended) of the original Physikalische Kristallographie. This project is still in its very early stages but is considered to be a promising one.

\section{Under consideration}

Translation into English, with updating and extension, of the Italian book by Giacovazzo, C. et al., Introduction to Modern Crystallography. This proposal already has OUP approval but has not yet (as at April 1990) been formally approved by the Book Series Committee.

Translation into English of the lavishly illustrated Italian book Il Meraviglioso Mondo dei Cristalli. This proposal seems unlikely to go further, mainly for reasons of cost.

Life's Molecular Machinery. Although this idea has met with some genuine enthusiasm, it is proving extremely difficult to find anyone combining a possession of the necessary expertise and of the necessary spare time to serve as its organizer/editor.

Other topics under consideration include Quasi-crystals, Diffuse Scattering, Classics of Crystal Growth, X-ray and Neutron Diffraction, Standard Data of Metal and Alloy
Structure Types, Direct Methods especially Maximum Entropy, Modern Crystal Optics and Compton Scattering.

\section{Guidelines for editors of conference proceedings}

The guidelines set out below are for prospective editors of proceedings of IUCr Crystallographic Symposia ( $\mathrm{IUCr}$ CS).

Inevitably, when the proceedings of a conference are prepared for publication in book form, there are particular difficulties in the maintenance of high standards, worthy of publication, in each of the contributions that are reported. (The fact that very many publications of conference proceedings these days fail in this respect is only too evident. We must not join their company.)

So far as the IUCr/OUP Book Series is concerned, it is our intention to publish conference proceedings only when we feel that the proper standards can be achieved: "proper standards' meaning standards fully comparable to those of the other publications of the Union.

At the IUCr General Assembly in August 1987, in Perth, Australia, this objective was expressed rather bluntly in the following resolution, which was approved:

Conference proceedings should be published in the IUCr Crystallographic Symposium Series only in cases where the individual contributions have been subjected to refereeing at the same standards as apply to contributions to the Union's journals.

In the journals, Acta Crystallographica and Journal of Applied Crystallography, it is the rule that every paper is refereed by at least two independent referees (one of whom may be the Co-editor involved). The editing of contributions which have been presented at a conference and which are then being considered for inclusion in a published proceedings is a different type of exercise from the editing of papers for a journal. For one thing, the terse kind of brevity demanded of a journal paper is less appropriate in a book. For another, there has to be some difference in the treatment given to officially 'invited' contributions, as opposed to the rest. For yet another thing, it is of crucial importance that the components of any book should be mutually consistent, mutually complementary and mutually well fitting, so as to give the proper coherence to the final production. Thus, the input of a book editor must be significantly stronger and also more personal than in the case of a journal. We also recognise that each conference, or school, or meeting has its own character, its own urgency and, doubtless, its own special problems, for which it is impossible to lay down instructions in advance.

Having noted all these points, we urge any prospective editor of a symposium proceedings to do everything possible in the particular circumstances that he or she encounters, to follow the spirit of the Perth resolution quoted above, so as to ensure the highest possible standards - standards comparable with those of the other publications of the Union.

\section{Meetings of the Book Series Committee}

The Committee met twice during the Perth Congress and will meet again during the Bordeaux Congress. Otherwise, all its business is transacted by correspondence.
20 April 1990
J. H. ROBERTSON, Chairman 
Appendix J: Budget estimates for the period to the Sixteenth General Assembly: determination of the unit contribution

\section{(a) Budget estimates}

The estimated budget for the General Fund (GF) is set out below, for the period until the next General Assembly. Since the budget estimates had to be prepared at a time when the decisions on many activities were still to be made, these estimates should be considered with due reserve. With this proviso, and in accordance with Statute 9.3, the Executive Committee presents to the General Assembly the following estimates for the three-year period 1 January 199031 December 1992.

General Fund

INCOME
Subscriptions from Adhering Bodies
Yield from investments and
banking accounts
Subventions from Unesco through
ICSU
EXPENDITURE
Administration
Subscriptions to ICSU and
bodies of ICSU
Administrative meetings
Scientific meetings
Transfers to other accounts

SwFr SwFr

400500

820000

$38000 \quad 1258500$

546700

13100

209000

189000

$270000 \quad 1227800$

\section{(b) Unit contribution}

According to Statute $5 \cdot 10(k)$, the General Assembly has to determine the unit contribution to be paid by the Adhering Bodies for the period to the next General Assembly. The Executive Committee recommends to the General Assembly that the unit contribution should be retained at its present level, SwFr 890, for the years 1991-1993.

ESTIMATED PROFIT 


\section{ANNEX II \\ Statutes and By-Laws of the International Union of Crystallography}

as Adopted by the Fourth General Assembly in 1957 and Amended by the Fifth General Assembly in 1960, the Sixth General Assembly in 1963, the Seventh General Assembly in 1966, the Eighth General Assembly in 1969, the Ninth General Assembly in 1972, the Tenth General Assembly in 1975, and the Eleventh General Assembly in $\mathbf{1 9 7 8}$

\section{Statutes}

\section{Objects of the Union}

1.1. The objects of the Union are

(a) to promote international cooperation in crystallography;

(b) to contribute to the advancement of crystallography in all its aspects, including related topics concerning the non-crystalline states;

(c) to facilitate international standardization of methods, of units, of nomenclature and of symbols used in crystallography;

(d) to form a focus for the relations of crystallography to other sciences.

1.2. For these purposes the Union shall have the power

(a) to adhere to the International Council of Scientific Unions;

(b) to organize international meetings and conferences on subjects falling within the purview of the Union;

(c) to promote international publication of crystallographic research and of crystallographic works;

(d) to set up Commissions or other bodies for special objects;

(e) to initiate, promote and coordinate crystallographic research requiring international cooperation;

$(f)$ to organize Special Projects which shall be financed independently of the regular operations of the Union;

$(g)$ to participate in Joint Commissions with other Unions or other scientific bodies in matters of interest to the Union;

(h) to perform all such other legal acts as are essential for or conducive to the objects of the Union including the constitution or organization of separate or independent bodies having an appropriate legal status;

(i) to receive into association existing regional organizations of crystallographers having substantially the same aims and objects as the Union; these organizations shall be known as Regional Associates of the Union;

(j) to receive into association existing international scientific organizations whose interests overlap with the aims and activities of the Union; these organizations shall be known as Scientific Associates of the Union.

\section{Organization and Legal Domicile}

$2 \cdot 1$. Under the name of International Union of Crystallography an Association has been organized and incorporated; it is governed by Articles 60 and following of the Swiss Civil Code and by the present Statutes of Incorporation.
2.2. The duration of the Union is not limited.

2.3. The legal domicile of the Union is in Geneva, Switzerland.

\section{Membership}

3.1. The members of the Union are its Adhering Bodies.

3.2. There shall be only one member for each Country.

3.3. In a Country the Adhering Body can be a National Academy, National Research Council or similar body, or a scientific society or group of such societies. Each Adhering Body shall form a National Committee for Crystallography to represent it in the Union.

3.4. Any number of Countries may agree to form a group in order to name or establish a single Adhering Body. This Body shall form a joint National or Regional Committee for Crystallography. Wherever the terms Country and National Committee for Crystallography are used in these Statutes or in the By-Laws, they shall be taken to include such groups of Countries and joint National or Regional Committees for Crystallography.

3-5. Membership in the Union shall be fully effective when the nature of the Adhering Body and the membership of the National Committee have been reported to and accepted by the General Assembly. Any replacement of an Adhering Body is subject to the approval of the Executive Committee and acceptance by the General Assembly. Any major change in the nature of an Adhering Body shall be considered valid only after it has been reported to and accepted by the General Assembly.

3.6. Adherence to the Union shall be in one of five Categories I-V with corresponding voting powers and contributions as set out in Statutes 5.5 and 9.4. A Body applying for adherence to the Union shall specify in which Category it wishes to adhere; this choice of Category, or any desired change in the Category, is subject to the approval of the Executive Committee and confirmation by the General Assembly.

3.7. Any extension of a joint adherence formed in accordance with Statute 3.4 is subject to the approval of the Executive Committee and acceptance by the General Assembly.

3.8. Participation in Special Projects [Statute 1.2(f)] shall not be obligatory. The extent of financial participation shall be a matter for special negotiation for each such project, except that the relationship between contribution and voting power within the project shall be that of the Category scheme defined in Statutes 5.5 and 9.4 to determine this relationship in the General Assembly. 
3.9. Each National Committee has the right to submit to the Union through the General Secretary questions within the competence of the Union.

$3 \cdot 10$. Any Adhering Body may withdraw from the Union if it has given notice of withdrawal at least six months before the end of the current financial year; it is required to fulfil its obligations relating to the time period when it was a member of the Union. Its membership and any further obligations shall then be suspended by the Executive Committee at the expiry of the notice of withdrawal. The withdrawal shall take effect when it has been reported to the General Assembly.

3.11. An Adhering Body which withdraws from the Union in accordance with Statute $3 \cdot 10$, or any Adhering Body whose membership is cancelled in accordance with Statutes $5 \cdot 12$ or $9 \cdot 6$, loses all rights in connexion with the Union.

$3 \cdot 12$. If the Countries of a group formed in accordance with Statute 3.4 agree that the group should be dissolved, or if a Country wishes to withdraw from such a group, with or without the agreement of the other Country or Countries of the group, the adherence of the original group shall be suspended by the Executive Committee at the expiry of an appropriate notice, provided that the original group has fulfilled its obligations. The termination of the original adherence shall take effect when the matter has been reported to the General Assembly. Pending this report, the Countries of the group, or any of them, may submit proposals for the continuation of their representation in the Union. In each of such proposals the nature of the Adhering Body, the membership of the National Committee and the desired Category of adherence shall be specified. These proposals are subject to the approval of the Executive Committee, which shall then make ad interim arrangements concerning these adherences. These arrangements are subject to acceptance by the General Assembly.

\section{Administration}

4.1. The work of the Union shall be conducted by

(a) the General Assembly;

(b) the Officers of the Union, constituting the Executive Committee;

(c) the Commissions as defined in Statute $8 \cdot 1$.

The composition and function of these bodies are defined in the following paragraphs, whose application is governed by the By-Laws.

\section{General Assembly}

5.1. The work of the Union shall be directed by the General Assembly which is composed of delegates appointed by the Adhering Bodies.

5.2. The Executive Committee is responsible to the General Assembly and shall participate in its deliberations. Members of the Executive Committee have no voting power in the General Assembly, except for the casting vote of the Chairman [Statute 5.8].

5.3. The General Assembly shall, as a rule, hold an ordinary meeting once every three years. The date and the place of the meeting, unless determined by the previous General Assembly, shall be determined by the Executive Committee. The General Secretary shall communicate the date and the place of the meeting to the National Commit- tees and to the Commissions at least twelve months in advance.

5.4. In special cases, the President of the Union, with the consent of the Executive Committee, may call an extraordinary meeting of the General Assembly. He shall do so at the request of one-fifth of the Adhering Bodies. The routine business of a General Assembly prescribed in Statute $5 \cdot 10$ shall normally be omitted, unless specifically included in the agenda; but an extraordinary General Assembly shall have the same powers, and be subject to the same rules, as an ordinary General Assembly, except where otherwise is stated in the Statutes and By-Laws. The General Secretary shall communicate the date and the place of the extraordinary General Assembly to the National Committees and to the Commissions at least eight months in advance if amendment of the Statutes is contemplated, or at least four months otherwise.

5.5. The voting power of an Adhering Body at General Assemblies shall be in accordance with its Category of adherence, as follows

$\begin{array}{lccccc}\text { Category } & \text { I } & \text { II } & \text { III } & \text { IV } & \text { V } \\ \text { Number of votes } & 1 & 2 & 3 & 4 & 5 .\end{array}$

5.6. Each Adhering Body, through its National Committee, shall make known to the General Secretary before the opening of each General Assembly the names of its delegates (and of their alternates, if any), and also the name of the chairman of the national or regional delegation. No Officer of the Union may be a member of any delegation, nor shall any person serve as a member of more than one delegation.

5.7. Normally each of the delegates present at a General Assembly shall have one vote only, but when for special reasons an Adhering Body cannot be fully represented at a General Assembly it may distribute its votes among a number of delegates smaller than the number of votes which that Adhering Body has in accordance with the Category in which it adheres; such a decision has to be made known to the General Secretary before the opening of the General Assembly concerned. Any Adhering Body not represented at a General Assembly may forward its views to the General Secretary by letter, and such views shall be made known to the General Assembly if received before voting takes place.

5.8. Except where otherwise provided in the Statutes and By-Laws, decisions of the General Assembly are taken by a majority of the votes cast. In the event of an equal division of votes the Chairman shall take the final decision.

5.9. No question which has not been placed on the agenda of business to be transacted at the General Assembly shall be discussed or put to the vote unless a proposal to that effect be approved by at least two-thirds of the votes there represented.

5.10. The General Assembly shall

(a) take appropriate action on any matters concerning membership in the Union [Statutes $3 \cdot 5,3 \cdot 6,3 \cdot 7,3 \cdot 10$, $3 \cdot 12$ and $5 \cdot 12] ;$

(b) elect the President, the Vice-President, the General Secretary, the Treasurer and the other Officers of the Union [Statutes $6 \cdot 1$ and 6.3];

(c) consider, and make decisions regarding, the confirmation of the appointments of Editors of publications of the Union [Statute $7 \cdot 1$ ]; 
(d) determine the number of elected members of each Commission set up by the General Assembly [Statutes $5 \cdot 11(c)$ and $8 \cdot 2]$

(e) elect the Chairmen and members of the Commissions [Statute 8.2];

( $f$ ) elect representatives of the Union on Joint Commissions with other Unions, and on other scientific bodies [Statutes $1 \cdot 2(\mathrm{~g})$ and $8 \cdot 5$ ];

(g) receive the reports on the activities of the Union and of its Commissions [Statutes 6.8 and 8.4 ];

(h) receive the audited accounts for the years elapsed since the previous General Assembly [Statute 9.1];

(i) on receipt of satisfactory reports or accounts, release the Treasurer, or any other Officer, or the Chairman or any member of any Commission or other body, from financial or other liability to the Union;

(j) determine the budget for general expenditure for the period to the next General Assembly, on the basis of the estimate prepared by the Executive Committee [Statutes $9 \cdot 2$ and $9 \cdot 3$ ];

(k) determine the unit contribution for the period to the next General Assembly [Statute 9.5];

(l) determine the general policy and the timetable for the period to the next General Assembly;

( $m$ ) give preliminary consideration to the activities of the Union for the three-year period following the next General Assembly.

5.11. The General Assembly shall have the power

(a) to amend these Statutes in accordance with Statute $13 \cdot 1$

(b) to formulate and amend By-Laws on any matters not covered by these Statutes;

(c) to set up any Commission or other body it may deem necessary for the administrative and scientific work of the Union, and to determine the terms of reference of such a body [Statute $1 \cdot 2(d)]$;

(d) to dissolve any Commission or other body set up in accordance with Statute $5 \cdot 11(\mathrm{c})$ when its existence is deemed no longer necessary;

(e) to determine the nature of Special Projects which shall be financed independently of the regular operations of the Union [Statute $1 \cdot 2(f)]$;

( $f$ ) to accept Regional Associates, to determine the nature of the association in each case, and to determine any mutual financial commitments;

( $g$ ) to accept Scientific Associates, to determine the nature of the association in each case, and to determine any mutual financial commitments;

(h) to decide on all other questions falling within the competence of the Union.

5.12. The General Assembly may cancel the membership of any Adhering Body of the Union for any serious cause; such a decision may only be taken after the member in question has been previously given an opportunity to furnish an explanation to the Executive Committee for forwarding to the General Assembly. At least three-fourths of the total number of the votes of all Adhering Bodies are required for cancellation.

\section{Executive Committee}

$6 \cdot 1$. The Officers of the Union constituting the Executive Committee are (a) the President;

(b) the Vice-President;

(c) the General Secretary;

(d) the Treasurer;

(e) the immediate Past President;

(f) six ordinary members.

6.2. The election of Officers of the Union shall be arranged in such a way that there will not be more than two Officers from any one Country. A person is regarded as belonging to the Country in which he is normally resident and where he conducts the main part of his work. In cases of doubt the General Assembly shall decide to which Country a person is considered to belong.

If during the period between General Assemblies the number of Officers from a Country is increased above two because of any change of Country of residence, the Officer or Officers who changed his or their Country of residence may continue his or their service until the close of the next General Assembly. If at that time the number of Officers from the Country concerned would remain above two, one or more of the Officers who changed his or their Country of residence shall be considered to have resigned.

$6 \cdot 3$. The offices of General Secretary and Treasurer may be combined and shall then be considered as a single office. Otherwise no person shall hold more than one office simultaneously. The voting power of the Officer holding the combined office of General Secretary and Treasurer shall not be more than that of either the General Secretary or the Treasurer.

6.4. The President holds office as President until the close of the ordinary General Assembly following his election, and continues as a member of the Executive Committee until the close of the ordinary General Assembly next but one following that of his election. He is not then eligible for immediate re-election to the office of President, nor to any other office in the Executive Committee.

The Vice-President holds office until the close of the ordinary General Assembly following his election. He is not eligible for immediate re-election to the same office.

The General Secretary and the Treasurer hold office until the close of the ordinary General Assembly following that of their election. They are eligible for immediate re-election to the same office, but shall not serve in that office for more than three full consecutive terms.

Three ordinary members are elected at each ordinary General Assembly and hold office until the close of the ordinary General Assembly next but one following that of their election. They are not eligible for immediate re-election to the same office.

In the event of a vacancy, through resignation, death or other cause, any Officer elected by the General Assembly to fill the unexpired term of office shall serve only to the end of the normal term of the Officer he replaces; at the end of this service he may be nominated for re-election for a full term to the same office.

6.5. The Executive Committee shall carry out the decisions of the General Assembly and give effect to the general policy of the Union as determined by the General Assembly.

6.6. During the periods between General Assemblies the Executive Committee shall have full power to carry on the business of the Union in all matters not specifically assigned by the Statutes, the By-Laws or the General Assembly to individuals or to Commissions or other bodies. If necessary, 
it may make ad interim arrangements in all matters assigned by the Statutes and By-Laws to the General Assembly.

6.7. In the event of an individual, a Commission or another body of the Union failing to act in any matter assigned to him or it by the Statutes, By-Laws or the General Assembly, the Executive Committee may, after reasonable notice to the individual or body in question, take action on behalf of the Union.

6.8. The Executive Committee shall report on its activities to the General Assembly. The action taken by the Executive Committee in accordance with Statutes 3.5, 3.6, $3 \cdot 7,3 \cdot 10,3 \cdot 12,6 \cdot 6,6 \cdot 7,7 \cdot 1,7 \cdot 2,8 \cdot 2,9 \cdot 6$ and $9 \cdot 9$ shall be included in this report. The report to the General Assembly shall be dispatched by the General Secretary to the National Committees and to the Commissions at least ten weeks before the meeting.

\section{Publications of the Union}

$7 \cdot 1$. The Editors of the publications of the Union are appointed by the Executive Committee for initial terms extending through not more than six years beyond the ordinary General Assembly following the appointment. Each initial appointment is subject to confirmation by that General Assembly. Reappointments may be made by the Executive Committee for terms of not more than three years, and are subject to confirmation by the ordinary General Assembly following the reappointment.

7.2. Co-editors and Assistant Editors are appointed by the Editors for terms of not more than three years, but they may be reappointed immediately for terms of the same length. The appointments and reappointments are subject to the approval of the Executive Committee.

7.3. Editors and Co-editors are members of the Commissions set up for their respective publications.

\section{Commissions and Joint Commissions}

8.1. The term 'Commission' shall be understood to include all Commissions, Committees, and other bodies of the Union with the exception of National Committees for Crystallography, and the Executive Committee and its subcommittees.

$8 \cdot 2$. The Chairmen and members of the Commissions are elected at each General Assembly. Subject to the approval of the Executive Committee, Commissions may co-opt further members during the periods between General Assemblies, and may fill vacancies arising from resignation, death or other cause. Members (but not Chairmen) may be nationals of or residents in a Country not adhering to the Union.

8.3. The Commissions shall be responsible to the General Assembly. They shall generally have full freedom in arranging their internal structure and work. They may formulate their own Rules of Procedure within the framework of the Statutes and By-Laws of the Union, and within their terms of reference.

8.4. The Chairmen shall report on the activities of the Commissions to the General Assembly. These reports shall reach the General Secretary at least fourteen weeks before the General Assembly and shall be dispatched by him to the National Committees and the Commissions at least ten weeks before the meeting.
8.5. The representatives of the Union on Joint Commissions and on other scientific bodies [Statute $1 \cdot 2(g)$ ] are elected at each General Assembly. For each such body one representative shall be designated as the chief representative of the Union. His obligations to report are the same as those of the Chairmen of the Commissions.

\section{Finance}

9-1. The Executive Committee shall be responsible to the General Assembly for all the financial affairs of the Union.

$9 \cdot 2$. The Chairman of each Commission (or other member approved by the Executive Committee) shall be responsible to the Executive Committee for any expenditure of funds by his Commission. Five months before each General Assembly he shall submit to the Executive Committee an estimate of the budget of his Commission for the period between that General Assembly and the one following it. He shall submit annually to the Executive Committee a revised budget for the ensuing year and a statement of accounts for the preceding year. His accounts shall be available for audit by the Executive Committee or its appointees.

9.3. The Executive Committee shall prepare an estimate of the budget for the period between the next General Assembly and that following it. This estimate shall be dispatched by the General Secretary to the National Committees and to the Commissions at least ten weeks before the meeting.

9.4. Each Adhering Body shall pay an annual subscriftion in accordance with its Category of adherence, as follows:

$\begin{array}{lccccc}\text { Category } & \text { I } & \text { II } & \text { III } & \text { IV } & \text { V } \\ \text { Number of unit contributions } & 1 & 3 & 6 & 10 & 15 .\end{array}$

The annual subscriptions are payable during the calendar year to which they apply.

$9 \cdot 5$. The unit contribution, stated in terms of a currency to be designated by the Executive Committee, shall be determined by the General Assembly for the period to the next General Assembly.

9.6. Any Adhering Body which is in arrears with its subscription for two years shall be warned and shall be deprived of its voting power. The membership of any Adhering Body which is in arrears for four years shall be automatically suspended and may be cancelled by the General Assembly under Statute 5.12. An Adhering Body whose membership has been suspended shall receive no privileges of the Union and incur no further responsibility for dues; it may be reinstated by action of the Executive Committee.

$9 \cdot 7$. The financing and management of publications of the Union shall be kept distinct from general expenditure. Editors and Co-editors shall be responsible to the Executive Committee for any receipts or expenditure of funds by them with respect to their publications.

9.8. The financing and management of Special Projects of the Union shall be kept distinct from the regular operations of the Union.

9.9. No funds may be solicited or accepted on behalf of the Union or any of its Commissions from any international, governmental or other agency or person without the prior approval of the Executive Committee. Any National Committee for Crystallography may however solicit funds within 
its own Country for the support of its own activities or in its capacity as host for a General Assembly, Congress or other meeting sponsored by the Union. Any funds, in the form of donations, legacies, or grants, accepted by the Executive Committee shall be used so far as is possible in accordance with the wishes of the donors.

\section{Liability}

10.1. The Union is liable only to the extent of its assets, and the Adhering Bodies are not individually liable for its corporate debts and liabilities.

10.2. The liabilities of the Adhering Bodies are limited to the payment of their annual subscriptions and to such contributions to the Special Projects of the Union as they may have pledged.

10.3. No Officer of the Union shall be individually liable for the corporate debts and liabilities of the Union. The Union shall indemnify any Officer or former Officer in respect of any claims laid against him in respect to his authorized actions on behalf of the Union. At its discretion the Executive Committee may extend this indemnity to other persons in respect of their authorized actions on behalf of the Union.

10.4. The Union shall not accept any liability for any personal loss, damage or accident sustained by an individual, not being an employee of the Union, engaged in any activity, including travel, on behalf of the Union.

\section{Auditor and Representation of the Union}

11.1. The Auditor of the Union shall be a person or corporation authorized to act as a public accountant. The Auditor shall be appointed by the Executive Committee on the recommendation of the Treasurer and maintained thereafter subject to the approval of the General Assembly.

$11 \cdot 2$. With the exception of cheques, all contracts and formal agreements involving the Union shall be signed by two Officers of the Union. The Executive Committee may restrict the power to sign a particular document or type of document to specific persons among the Officers; and it shall determine rules for the signing of cheques.

$11 \cdot 3$. The President shall be the official representative of the Union on all other civil and legal occasions and in dealing with other organizations. He may in this respect delegate his powers to another Officer of the Union, or, with approval of the Executive Committee, to any other person.

\section{Dissolution of the Union}

12.1. The Union shall not be dissolved except on a motion presented at a General Assembly. If a motion to dissolve is to be presented, the notice for that General Assembly as given under Statute $5 \cdot 3$ or $5 \cdot 4$ shall include a statement of the motion to dissolve and shall refer specifically to this Statute. Such a motion shall be presented to the General Assembly without amendment and at least three-fourths of the votes there represented shall be required for dissolution.

In the event that less than three-fourths of the total number of the votes of all Adhering Bodies are represented at the General Assembly, a postal ballot may be arranged, and in such a postal ballot at least three-fourths of the total number of the votes of all Adhering Bodies shall be required for dissolution.

$12 \cdot 2$. In the event of dissolution of the Union in accordance with Statute $12 \cdot 1$, the General Assembly shall appoint a special Committee, reporting to the International Council of Scientific Unions, for the liquidation of the assets of the Union. The net assets shall be given to one or more, preferably international, organizations or institutions which shall spend the assets for purposes so far as is possible in accordance with the objects of the Union.

\section{Statutes}

13.1. Amendments to the Statutes require action at a General Assembly. An amendment is adopted at such an Assembly only if (i) at least two-thirds of the votes represented at the General Assembly are affirmative and (ii) if these affirmative votes amount to more than half the total number of the votes of all Adhering Bodies. In the event that the vote on a proposed amendment satisfies condition (i) but not condition (ii), the Executive Committee may refer the proposed amendment to a postal ballot of the Adhering Bodies. If the proposed amendment then obtains affirmative votes amounting to more than half the total number of the votes of all Adhering Bodies, the amendment is adopted.

Proposals for amendments may be made by the Executive Committee or by any National Committee. Such proposals made by National Committees shall reach the General Secretary at least six months in advance of the General Assembly. The General Secretary shall dispatch these proposals, and those made by the Executive Committee, to the National Committees and to the Commissions at least four months before the meeting.

13.2. The present English text shall be considered the authoritative text in the interpretation of these Statutes. Where disputes arise concerning this interpretation, the matter shall be decided by the General Assembly, or, during the periods between General Assemblies, by a ruling of the President of the Union.

\section{By-Laws}

\section{General Assembly}

1.1. The agenda of business to be transacted at a General Assembly shall be determined by the Executive Committee and shall be dispatched by the General Secretary to the
National Committees and to the Commissions at least ten weeks before the meeting.

1.2. Any National Committee and any Commișion the Union may propose business to be transacted at a General Assembly. Such proposals shall reach the General 
Secretary at least four months before the meeting, and shall be included in the agenda of the General Assembly.

1.3. The General Assembly may provisionally determine the date and the place of the next but one ordinary meeting of the General Assembly.

1.4. Chairmen of the National Committees and of the Commissions, and representatives of Regional Associates and Scientific Associates may attend the General Assembly and take part in the discussions but shall have no voting power. The President may invite representatives of scientific bodies, or individuals, to attend the General Assembly; such invited guests may take part in the discussions but shall have no voting power. Other interested persons may also attend the General Assembly but they shall not take part in the discussions, unless specifically invited or permitted to do so by the Chairman, and they shall have no voting power.

At the discretion of the Chairman any or all of the persons attending the General Assembly under this By-Law may be required to withdraw.

1.5. If a delegate to a General Assembly is absent from a session of the Assembly, his place may be taken by any of the alternates nominated to the Assembly under Statute 5.6 provided that the Secretary of the Assembly is notified before the beginning of the session of the name of the delegate and of the name of the alternate, either by the delegate or by the chairman of his delegation. In general no such substitution may take place during a session of the Assembly, but the Chairman of the Assembly may permit substitution to be made under special circumstances.

$1 \cdot 6$. The names of the representatives of a Body whose application for adherence to the Union has been received and declared in good order by the Executive Committee under By-Law $2 \cdot 9(a)$ shall be made known to the General Secretary as prescribed in Statute $5 \cdot 6$. These representatives shall be seated with the delegates of the Adhering Bodies during the preliminary ceremonies and the initial business of the General Assembly. At the discretion of the Chairman or by a vote of the Assembly, the representatives may be required to withdraw during the discussion of and voting on matters concerning adherence to the Union. The delegates of a new member may take their seats among the other delegates as soon as the General Assembly has accepted their Adhering Body as a member of the Union.

1.7. Unless decided otherwise by the General Assembly, matters concerning adherence to the Union shall take precedence over all other business at the first business session of the General Assembly, and shall normally precede the reading of the minutes and the discussions of matters arising therefrom.

1.8. Delegates of an Adhering Body may not vote on any matter concerning its membership in the Union.

1.9. In the event of the General Assembly considering a change in a group of Countries according to Statute $3 \cdot 12$, the delegates from the Countries belonging or previously belonging to the group may not vote on any matters concerning the representation in the Union of any of these Countries. After acceptance of the ad interim arrangements made by the Executive Committee under Statute $3 \cdot 12$, these delegates have full voting power.

$1 \cdot 10$. The delegates of new members may not vote on any matters concerning adherence to the Union, nor on any matters concerning the adoption of the minutes of the previous General Assembly, during the General Assembly at which they themselves are admitted.

1.11. The General Secretary shall post on the official bulletin board of the General Assembly the names of the Chairmen and members (and alternates, if any) of the delegations and the numbers of votes represented by them.

1.12. During the General Assembly any delegate (or alternate) and any Officer of the Union is considered to have been notified of any action of the General Assembly, or of the Executive Committee, or of any Commission, if one of the two following procedures is adopted

(a) a notice is placed in the mail box or other location at which the delegate (or alternate) or the Officer is accustomed to receive his mail during the course of the General Assembly, or

(b) a notice is handed to the designated Chairman of each delegation with the specific request that he communicate its contents to his delegation, and to the General Secretary with the specific request that he communicate its contents to the Executive Committee,

provided that in either case a similar notice is posted on the official bulletin board.

1.13. Minutes of the meetings of the General Assembly shall be made. Copies of the draft minutes shall be communicated by the General Secretary to the National Committees, to the Officers of the Union and to the Chairmen of its Commissions. After approval at a subsequent General Assembly, two copies of the definitive minutes shall be signed by the Chairman and the Secretary of the session at which they are approved, and shall be kept by the President and the General Secretary.

\section{Executive Committee}

2.1. The Executive Committee shall meet at each General Assembly. There shall be at least two additional meetings during the period between General Assemblies, unless the Executive Committee by a postal vote decides otherwise.

$2 \cdot 2$. The Executive Committee shall make nominations to the General Assembly for the Officers of the Union, for the Chairmen and members of the Commissions, and for representatives on Joint Commissions and on other scientific bodies. Normally these nominations shall be made after a preceding postal communication with the National Committees. In each case in which an Officer of the Union is nominated for another office, either by the Executive Committee or by delegates to the General Assembly [ByLaw 7.2], the Executive Committee shall also include a nomination for the office which would be vacated if the election to the other office occurs. If the election to the other office does not occur and if the Officer's term has not expired, the nomination to the office which would have been vacated shall not be considered.

2.3 . In the event of the resignation, death or disability of the President, the Vice-President shall assume the office of President until the close of the next ordinary General Assembly.

In the event of the resignation, death or disability of the Vice-President, the Executive Committee may appoint one of its members to serve as Vice-President until the close of the next ordinary General Assembly.

In the event of such circumstances that the General Secretary or the Treasurer cannot carry out his duties, the 
other shall assume those duties until the Executive Committee has considered the situation. In that event the Executive Committee may, but need not, appoint a new General Secretary or Treasurer to serve until the close of the next ordinary General Assembly.

In the event of the resignation, death or disability of an ordinary member of the Executive Committee, the Executive Committee may co-opt a new member to serve until the close of the next ordinary General Assembly.

The accession of an Officer of the Union to a new office under the conditions of this By-Law shall be accompanied by his resignation from the office to which he was previously elected, but service under this By-Law shall not affect his eligibility for immediate re-election to the new office.

$2 \cdot 4$. Any Officer unable to attend a meeting of the Executive Committee may designate a deputy to attend that meeting. Such a deputy shall be named in writing to the President or the General Secretary. He shall have no voting power and shall not be counted as part of a quorum.

$2 \cdot 5$. The President, on his own initiative or at the request of the Executive Committee, may invite any individual to be present at a meeting of the Executive Committee; such an invited guest may take part in the discussions but shall have no voting power.

2.6. At a meeting of the Executive Committee two-thirds (fractional parts neglected) of the Officers specified by Statutes $6 \cdot 1$ and $6 \cdot 3$, excluding any who have resigned or died, shall constitute a quorum; and decisions shall be taken by a simple majority of the Officers present and voting. The Chairman of the meeting shall not vote in open ballots; but in the event of an equal division of votes the Chairman may take the final decision. In secret ballots required by the Statutes or By-Laws or ordered by the Chairman he may vote at his discretion. If he does not vote and there is an equal division of votes he may take the final decision. If he has voted in a secret ballot he may not take the final decision, and must leave it to further discussion and ballot.

$2 \cdot 7$. During the period between meetings of the Executive Committee, voting may take place by post. Adoption of a proposal shall require affirmative votes from two-thirds (fractional parts neglected) of the Officers specified by Statutes $6 \cdot 1$ and $6 \cdot 3$, excluding any who have resigned or died. No decision on any proposal other than calling or cancelling a meeting of the Executive Committee shall be made by postal vote in the event that at least two Officers express the wish that the matter concerned should first be given more or further consideration, either by correspondence or at a meeting of the Executive Committee.

$2 \cdot 8$. Minutes of the meetings of the Executive Committee shall be made. Two copies of the minutes shall be signed by the Chairman and the Secretary of the meeting at which they are approved, and shall be kept by the President and the General Secretary. A summary of the draft minutes of meetings of the Executive Committee shall be despatched by the General Secretary to the National Committees within ten weeks of the conclusion of each meeting.

2.9. In addition to the obligations described in the Statutes and elsewhere in these By-Laws, the Executive Committee shall

(a) receive and report on applications for adherence to the Union if the nature of the applying Body and the membership of the National Committee have been duly reported to and considered to be in good order by the Executive Committee; pending the next General
Assembly the Executive Committee may in the case of such applications provide such services of the Union as it deems proper;

(b) consider and report on any other questions concerning adherence to the Union;

(c) present an annual report, including an audited statement of receipts and expenditure, to the National Committees;

(d) report to the Commercial Registry of Geneva any changes in the registered information concerning the Union;

(e) have the power to appoint representatives on scientific bodies not belonging to the Union.

\section{President}

3.1. The President of the Union is Chairman of the General Assembly and of the Executive Committee. In the absence of the President from a session or meeting, the Vice-President, or if he is not present another Officer of the Union designated by the Executive Committee, shall act as Chairman.

3.2. The President of the Union is an ex officio member, with voting power, of all Commissions of the Union.

\section{General Secretary}

4.1. The General Secretary of the Union is Secretary of the General Assembly and of the Executive Committee. In his absence from a session or meeting, another Officer of the Union designated by the Executive Committee shall act as Secretary.

4.2. The General Secretary of the Union is an ex officio member, with voting power, of all Commissions of the Union.

4.3. The General Secretary is responsible for conducting the ordinary business of the Union, with the exception of the financial administration, and for keeping its records.

\section{Treasurer}

5.1. The Treasurer of the Union is responsible for the financial administration of the Union and for keeping its accounts.

5.2. The Treasurer is an ex officio member of all Commissions of the Union, with voting power only for those questions which may involve the Union in financial commitments.

\section{Commissions of the Union}

$6 \cdot 1$. The Chairmen of the Commissions and the chief representatives on Joint Commissions or other bodies shall forward records of all meetings of the Commissions to the President and the General Secretary. They shall report annually on the activities of these bodies to the Executive Committee.

6.2. If funds are provided for the use of a Commission, it may make its own financial arrangements, with the prior approval of the Executive Committee and subject to the provisions of the Statutes and By-Laws. In cases where the Executive Committee has given prior approval, payments toward travelling expenses of Chairmen and members of 
Commissions may be made from the general funds of the Union.

6.3. No person who has served for three consecutive full terms of office on a Commission is eligible for nomination for a fourth consecutive term of service on the same Commission except as Chairman. In no case is any person eligible for more than four consecutive full terms of service on the same Commission. These limitations do not apply to Editors [Statute 7.1], Co-editors [Statute 7.2] and ex afficio members. Any Commission, in its Rules of Procedure, may reduce the length of service specified here.

6.4. In the event of the resignation, death or disability of the Chairman of any Commission, the Executive Committee shall appoint a member of that Commission to serve as Chairman until the close of the General Assembly following this appointment.

\section{Nominations and Elections}

7.1. All delegates (and alternates) shall be notified of the nominations presented by the Executive Committee under By-Law 2.2 for the Officers of the Union as early as possible and at least ninety-six hours before the scheduled commencement of the session of the General Assembly at which the vote is to be taken.

7.2. After the delegates have been notified of the nominations by the Executive Committee as prescribed in By-Law $7 \cdot 1$, other nominations for Officers of the Union may be made by any six or more delegates. Such nominations shall be made in writing to the General Secretary not less than thirty-six hours before the voting session and shall be accompanied by a written statement that the consent of the nominees has been obtained. These nominations shall be posted by the General Secretary on the official bulletin board not less than twenty-four hours before that session.

7.3. Recommendations from each Commission for the Chairman and members of the Commission shall be made in writing to the General Secretary not less than seventy-two hours before the voting session of the General Assembly. These recommendations shall be approved by a majority of the members of the Commission and shall be accompanied by a written statement that the consent of the persons recommended has been obtained. All delegates (and alternates) shall be notified of the nominations presented by the Executive Committee under By-Law $2 \cdot 2$ for the Chairman and members of each Commission at least forty-eight hours before the voting session.

7.4. After the delegates have been notified of the nominations by the Executive Committee as prescribed in By-Law $7 \cdot 3$, other nominations for the Chairman and members of each Commission may be made by any six or more delegates. Such nominations shall be made in writing to the General Secretary not less than twenty-four hours before the voting session and shall be accompanied by a written statement that the consent of the nominees has been obtained. These nominations shall be posted by the General Secretary on the official bulletin board not less than twelve hours before that session.

7.5. In voting for the President, Vice-President, General Secretary and Treasurer of the Union, each of these offices shall be taken separately and voting shall be by secret ballot. A simple majority of the votes represented by the delegates present at the voting session shall be required for election.
If there is only one candidate for one of these offices, his nomination shall be presented to the General Assembly and the candidate concerned shall be considered as elected. If there are two candidates or more, and an election is not achieved after two ballots, the candidate receiving the smallest number of votes in the second ballot shall be removed from the list. If an election is not achieved after a third ballot, this procedure shall be repeated until an election is achieved. Any ballot form showing more than one mark shall be invalid. Any contingency arising during the balloting shall be resolved by a ruling of the Chairman of the General Assembly.

7.6. The election of the ordinary members of the Executive Committee shall be by secret ballot, the ballot form showing the nominations presented by the Executive Committee and the nominations made by delegates. A simple majority of the votes represented by delegates present at the voting session shall be required for election. If there are not more candidates than vacancies, the nominations shall be presented to the General Assembly and the candidates shall be considered as elected. If there are more candidates than vacancies and all vacancies are not filled by election at the first ballot, a second ballot shall be arranged containing the names of the candidates not elected. If there are vacancies after the second ballot, the balloting procedure shall be repeated until all vacancies are filled; for each of these subsequent ballots the name of the candidate receiving the smallest number of votes on the preceding ballot shall be removed from the list. Any ballot form showing more marks than the appropriate number of vacancies shall be invalid. Any contingency arising during the balloting shall be resolved by a ruling of the Chairman of the General Assembly.

7.7. In the event that an election must be held to fill the unexpired term of an office vacated by an ordinary member [Statute 6.4], the nominations for this office shall be distinct from the nominations for ordinary members for full terms. A person may be nominated for both categories, but can be elected to only one office [Statute 6.3]. If ballots are required in the elections for both categories, the ballots for the full-term offices shall take place first. A person who has been elected to two consecutive non-full terms is not eligible, on completion of his second term, for immediate re-election as an ordinary member of the Executive Committee.

7.8. In voting for the Chairmen and members of the Commissions each Commission shall be considered separately. For the election of the Chairmen the procedure described in By-Law 7.5 shall be followed. For the election of the members of the Commissions the procedure described in By-Law 7.6 shall be followed except that no more than two ballots shall be held. Any vacancies still remaining may be filled as provided in Statute $8 \cdot 2$.

7.9. The procedure for the nomination and election of representatives of the Union on Joint Commissions and on other scientific bodies is so far as is possible the same as that for the nomination and election of the Chairmen and members of the Commissions.

\section{By-Laws}

8.1. These By-Laws may be amended or suspended at any General Assembly and at least two-thirds of the votes 
there represented are required for an amendment or suspension. A motion to amend or suspend, if not already included in the agenda of business of the General Assembly, may be placed there by the procedure of Statute $5 \cdot 9$. No notice is required for a proposal to suspend the time limits prescribed by By-Laws $7 \cdot 2$ and $7 \cdot 4$. Notification of any other motion to amend or suspend the By-Laws must be given by its originators to all delegates (and alternates) and to all Officers of the Union in accordance with the procedure prescribed in By-Law 1.12, at least forty-eight hours before the session of the General Assembly at which the motion is to be considered.

$8 \cdot 2$. Words importing the male sex in the Statutes and By-Laws shall include the female sex.

8-3. The present English text shall be considered the authoritative text in the interpretation of these By-Laws. Where disputes arise concerning this interpretation, the matter shall be decided by the General Assembly, or during the periods between General Assemblies, by a ruling of the President of the Union.

\section{APPENDIX}

Timetable in Preparation for General Assembly

\begin{tabular}{|c|c|c|c|}
\hline & & Statute & $y-1$ \\
\hline months & $\begin{array}{l}\text { Notice of date and place of ordinary General Assembly to National Committees and } \\
\text { Commissions }\end{array}$ & $5 \cdot 3$ & \\
\hline 8 months & $\begin{array}{l}\text { Notice of date and place of extraordinary General Assembly to National Committees } \\
\text { and Commissions, if amendment of Statutes is contemplated }\end{array}$ & $5 \cdot 4$ & \\
\hline 6 months & Proposals for amendments to Statutes to General Secretary & $13 \cdot 1$ & \\
\hline 5 months & Estimated budgets from Commissions to Executive Committee & $9 \cdot 2$ & \\
\hline 4 months & Proposals for agenda of General Assembly to General Secretary & & \\
\hline 4 months & $\begin{array}{l}\text { Notice of date and place of extraordinary General Assembly to National Committees } \\
\text { and Commissions, if amendment of Statutes is not contemplated }\end{array}$ & $5 \cdot 4$ & \\
\hline 4 months & Proposals for amendments to Statutes to National Committees and Commissions & $13 \cdot 1$ & \\
\hline 14 weeks & Reports of Commissions to General Secretary & $8 \cdot 4$ & \\
\hline 10 weeks & Report of Executive Committee to National Committees and Commissions & $6 \cdot 8$ & \\
\hline 10 weeks & Reports of Commissions to National Committees and Commissions & $8 \cdot 4$ & \\
\hline 10 weeks & Budget to National Committees and Commissions & $9 \cdot 3$ & \\
\hline 10 weeks & Agenda to National Committees and Commissions & - & \\
\hline \multicolumn{4}{|c|}{ Timetable during General Assembly } \\
\hline 'Before’ & $\begin{array}{l}\text { Notice by National Committees to General Secretary of names of delegates, alternates } \\
\text { and chairmen of delegations, and of distribution of votes if not one per delegate }\end{array}$ & $5 \cdot 6,5 \cdot 7$ & \\
\hline 96 hours & Nominations by Executive Committee for Officers of Union & - & \\
\hline 72 hours & $\begin{array}{l}\text { Recommendations by Commissions to General Secretary for Chairmen and members } \\
\text { of Commissions }\end{array}$ & - & \\
\hline 48 hours & Nominations by Executive Committee for Chairmen and members of Commissions & - & \\
\hline 48 hours & Notification of motion to amend or suspend By-Laws & - & \\
\hline 36 hours & Notice to General Secretary of nominations by delegates for Officers of Union & - & \\
\hline 24 hours & Posting of nominations by delegates for Officers of Union & - & \\
\hline 24 hours & $\begin{array}{l}\text { Notice to General Secretary of nominations by delegates for Chairmen and members } \\
\text { of Commissions }\end{array}$ & - & \\
\hline 12 hours & Posting of nominations by delegates for Chairmen and members of Commissions & - & \\
\hline
\end{tabular}


ANNEX III

\title{
Committees, Commissions and representatives on Regional and Scientific Associates and bodies not belonging to the Union
}

\author{
Memberships of bodies belonging to the Union
}

\section{EXECUTIVE COMMITTEE}

President

A. Authier*

Laboratoire de Minéralogie et

Cristallographie,

Université Pierre et

Marie Curie,

4 place Jussieu,

F-75252 Paris Cedex 05,

France

Vice-President
A. Kálmán* (Hungary)

General Secretary and Treasurer

A. I. Hordvik*

Department of Chemistry, IMR University of Tromsö, N-9000 Tromsö, Norway

\section{Immediate Past President}

M. Nardelli* (Italy)

\section{Ordinary members}

R. Chidambaram $\dagger$ (India)

P. W. Codding $\dagger$ (Canada)

P. Coppens* (USA)

R. Diamond* (UK)

J. Harada† (Japan)

Y. T. Struchkov* (USSR)

\section{Executive Secretary}

J. N. King

International Union of

Crystallography,

5 Abbey Square,

Chester CH1 2HU,

England

\footnotetext{
* Until the close of the Sixteenth General Assembly (1993).

† Until the close of the Sevenieenth General Assembly (1996).
}

\author{
COMMISSION ON JOURNALS \\ Chairman and Editor of Acta \\ Crystallographica \\ C. E. Bugg \\ $\mathrm{CMC} / \mathrm{Comprehensive} \mathrm{Cancer}$ \\ Center, \\ University of Alabama at \\ Birmingham, \\ UAB Station, Box 79THT, \\ Birmingham, AL 35294, \\ USA
}
Co-Chairman and Editor of Journal of Applied Crystallography
A. M. Glazer
Clarendon Laboratory, University of Oxford, Parks Road, Oxford OX1 3PU, England

Co-editors

J. Albertsson (Sweden; Acta)

N. W. Alcock (UK; Acta)

T. Ashida (Japan; Acta)

I. D. Brown (Canada; Acta) (as from September 1990)

H. Burzlaff (Germany; Acta) (until the end of 1991)

P. W. Codding (Canada; Acta)

B. M. Craven (USA; Acta)

A. Durif (France; Actä)

A. Gavezzotti (Italy; Acta) (until the end of 1991)

J. P. Glusker (USA; Acta)

S. R. Hall (Australia; Acta)

M. M. Harding (UK; Acta)

J. R. Helliwell (UK; Acta)

H. Hope (USA; Acta)

C. J. Howard (Australia; JAC) (as from September 1990)

M. B. Hursthouse (UK; Acta)

H. Iwasaki (Japan; JAC)

A. Kálmán (Hungary; Acta)

J. I. Langford (UK; JAC)

P. F. Lindley (UK; Acta)

B. Morosin (USA; JAC)

K. W. Muir (UK; Acta)

M. Nardelli (Italy; Acta) (as from February 1991)

M. Ohmasa (Japan; Acta)

C. Pascard (France; Acta)

E. Prince (USA; $J A C$ )

S. E. Rasmussen (Denmark; $J A C$ )
W. H. E. Saenger (Germany; Acta)

V. I. Simonov (USSR; Acta)

J. C. H. Spence (USA; Acta)

H. Steinfink (USA; Acta)

G. Will (Germany; JAC)

Book-Review Editor

R. O. Gould (UK; Acta and J.AC)

Ex officio member

F. H. Allen (UK) (as Chairman of the Commission on Crystallographic Data)

\section{COMMISSION ON STRUCTURE REPORTS \\ Chairman and Editor \\ G. Ferguson \\ Department of Chemistry, University of Guelph, Guelph, Ontario, Canada N1G 2W1}

Co-editors

G. Bergerhoff (Germany)

J. Iball (UK)

S. N. Scrimgeour (UK)

J. Trotter (Canada)

Ex officio member

F. H. Allen (UK) (as Chairman of the Commission on Crystallographic Data)

\section{COMMISSION ON INTER-} NATIONAL TABLES

Chairman and Editor of Volume $C$

A. J. C. Wilson

17 Botolph Lane, Cambridge CB2 3RE, England

Editor of Volume $A$

Th. Hahn (Germany)

Editor of Volume $B$

U. Shmueli (Israel)

Editor of Volume $D$

A. Authier (France)

Editors of Volume $E$

V. Kopsky (Czechoslovakia)

D. B. Litvin (USA) 
COMMISSION ON BIOLOGICAL MACROMOLECULES

Chairman

G. G. Dodson

Department of Chemistry, University of York, Heslington, York YO1 5DD England

\section{Elected members}

E. N. Baker (New Zealand)

M. Bolognesi (Italy)

V. V. Borisov (USSR)

P. M. D. Fitzgerald (USA)

M. N. G. James (Canada)

A. C. T. North (UK)

D. Suck (Germany)

M. Vijayan (India)

COMMISSION ON CHARGE, SPIN AND MOMENTUM DENSITIES

Chairman

W. Schülke

Institute für Physik, Universität Dortmund, Postfach 500500 , W-4600 Dortmund, Germany

\section{Elected members \\ J.-X. Boucherle (France) \\ D. E. Ellis (USA) \\ D. Feil (Netherlands) \\ J. B. Forsyth (UK) \\ K. Hermansson (Sweden) \\ G. Itoh (Japan) \\ P. Mijnarends (Netherlands) \\ K. Schwarz (Austria) \\ E. D. Stevens (USA) (Secretary)}

Ex officio member

S. A. Mason (France) (as Chairman of the Commission on Neutron Diffraction)

COMMISSION ON CRYSTAL GROWTH AND CHARACTERIZATION OF MATERIALS

Chairman

C. Paorici

Physics Department, University of Parma, I-43100 Parma, Italy

Elected members

J. Barthel (Germany)

P. Bennema (Netherlands)

K. W. Benz (Germany)

R. Boistelle (France)

P. M. Dryburgh (UK)

H. Klapper (Germany) (Secretary)

K. Lal (India)

T. Nishinaga (Japan)
Ex officio members

V. V. Osiko (USSR) (as Representative of the International Organization of Crystal Growth)

A. M. Glazer (UK) (as Editor of Journal of Applied Crystallography)

\section{COMMISSION ON CRYSTALLO-} GRAPHIC APPARATUS

Chairman

D. C. Creagh

Physics Department, University College, UNSW, Northcott Drive, Campbell, ACT 2600, Australia

\section{Elected members}

B. W. Batterman (USA)

G. T. De Titta (USA)

H. Hashizume (Japan)

J.-k. Liang (People's

Republic of China)

L. F. Malakhova (USSR)

J. S. Olsen (Denmark)

F. Tuinstra (Netherlands)

\section{COMMISSION ON CRYSTALLO-} GRAPHIC COMPUTING

\section{Chairman}

H. D. Flack

Laboratoire de Cristallographie, 24 quai Ernest-Ansermet, CH-1211 Genève 4, Switzerland

\section{Elected members}

H.-f. Fan (People's Republic of China)

N. W. Isaacs (UK)

A. J. Olson (USA)

G. Reck (Germany)

M. I. Sirota (USSR)

D. L. M. Viterbo (Italy)

K. D. Watenpaugh (USA)

Ex officio member

F. H. Allen (UK) (as Chairman of the Commission on Crystallographic Data)

\section{COMMISSION ON CRYSTALLO-} GRAPHIC DATA

Chairman

F. H. Allen

Crystallographic Data Centre, University Chemical

Laboratory,

Lensfield Road,

Cambridge CB2 1EW,

England
Elected members

J. Danielsen (Denmark)

S. R. Hall (Australia)

T. F. Koetzle (USA)

J. H. Noordik (Netherlands)

J. R. Rodgers (Canada)

W. B. Schweizer (Switzerland)

K. Simon (Hungary)

M. G. Trömel (Germany)

N. Yasuoka (Japan)

Ex officio members

C. E. Bugg (USA) (as Chairman of the Commission on Journals)

G. Ferguson (Canada) (as Chairman of the Commission on Structure Reports)

H. D. Flack (Switzerland) (as Chairman of the Commission on Crystallographic Computing)

E. N. Maslen (Australia) (as Director of Archiving and Crystallographic Information) (appointed June 1991)

\section{COMMISSION ON CRYSTALLO-} GRAPHIC NOMENCLATURE

\section{Chairman}

S. C. Abrahams

Physics Department, Southern Oregon State College, Ashland, OR 97520-5074, USA

Ex officio members

C. E. Bugg (USA) (as Editor of Acta Crystallographica)

A. M. Glazer (UK) (as Editor of Journal of Applied Crystallography)

G. Ferguson (Canada) (as Editor of Structure Reports)

Th. Hahn (Germany) (as Editor of Volume A of International Tables)

U. Shmueli (Israel) (as Editor of Volume B of International Tables)

A. J. C. Wilson (UK) (as Editor of Volume $\mathrm{C}$ of International Tables)

A. Authier (France) (as Editor of Volume D of International Tables)

V. Kopsky (Czechoslovakia) (as Editor of Volume $\mathrm{E}$ of International Tables)

D. B. Litvin (USA) (as Editor of Volume $\mathrm{E}$ of International Tables)

J. H. Robertson (UK) (as Chairman of IUCr/OUP Book Series Committee) 
J. P. Glusker (USA)

(as Chairman of the Commission on Crystallographic Teaching)

(appointed June 1991)

\section{COMMISSION ON CRYSTALLO- GRAPHIC TEACHING}

\section{Chairman}

J. P. Glusker

Institute for Cancer Research, Fox Chase Cancer Center, 7701 Burholme Avenue, Philadelphia, PA 19111, USA

\section{Elected members}

L. A. Aslanov (USSR)

I. D. Brown (Canada)

C. M. Gramaccioli (Italy)

M. J. Laing (South Africa)

P. Paufler (Germany)

H. von Philipsborn (Germany) (Secretary)

W. T. Robinson (New Zealand)

M.-c. Shao (People's

Republic of China)

R. Srinivasan (India)

\section{COMMISSION ON ELECTRON} DIFFRACTION

\section{Chairman}

J. M. Cowley

Department of Physics, Arizona State University, Tempe, AZ 85287-1504, USA

\section{Elected members \\ L. Kihlborg (Sweden) \\ K.-h. Kuo (People's Republic of China) \\ D. W. H. Rankin (UK) \\ J. W. Steeds (UK) \\ M. A. Van Hove (USA) (as from July 1991, replacing M. Prutton who had resigned) \\ L. V. Vilkov (USSR) \\ K. Yagi (Japan)}

\section{COMMISSION ON NEUTRON} DIFFRACTION

\section{Chairman}

S. A. Mason Institut Laue-Langevin, 156X, F-38042 Grenoble Cedex, France

\section{Elected members \\ A. Albinati (Italy) \\ Y. Endoh (Japan) \\ B. Lebech (Denmark) \\ B. M. Powell (Canada) \\ W. Prandl (Germany)}

E. Prince (USA)

A. S. Sequeira (India)

J. W. White (Australia)

C. T. Ye (People's Republic of China)

\section{COMMISSION ON POWDER DIFFRACTION \\ Chairman \\ R. A. Young School of Physics, \\ Georgia Institute of Technology, Atlanta, GA 30332, USA}

\section{Elected members \\ Z. Bojarski (Poland) \\ D. E. Cox (USA)}

J. Fiala (Czechoslovakia)

A. Hewat (France)

R. J. Hill (Australia) (Secretary)

J. I. Langford (UK)

D. Louër (France)

P.-E. Werner (Sweden)

T. Yamanaka (Japan)

Ex officio member

L. K. Frevel (USA)

(as representative of the JCPDS-ICDD)

\section{COMMISSION ON SMALL MOLECULES}

\section{Chairman}

W. L. Duax

Medical Foundation of Buffalo, 73 High Street, Buffalo, NY 14203, USA

\section{Elected members}

P. W. Codding (Canada)

G. Gilli (Italy)

F. H. Herbstein (Israel)

J. A. K. Howard (UK)

J.-l. Huang (People's Republic of China)

B. Kojic-Prodic (Yugoslavia)

M. F. Mackay (Australia)

J. J. Stezowski (USA)

Y. T. Struchkov (USSR)

\section{COMMISSION ON SYNCHROTRON} RADIATION

\section{Chairman}

J. R. Helliwell Department of Chemistry, University of Manchester, Manchester M13 9PL, England

\section{Elected members}

Y. Amemiya (Japan)

M. Colapietro (Italy)
G.-B. M. Hedman (USA)

W. A. Hendrickson (USA)

A. H. Kvick (France)

M. Sauvage-Simkin (France)

B. Tolochko (USSR)

G. Will (Germany)

Ad interim COMMISSION ON APERIODIC CRYSTALS (established, with this amended title, by the Executive Committee in April 1991)

\section{Chairman}

J. M. Pérez-Mato

Departamento de Fisica de la

Materia Condensada, Universidad del Pais Vasco, Apartado 644, E-48080 Bilbao, Spain

Members

G. C. Chapuis (Switzerland)

M. Farkas-Jahnke (Hungary)

M. L. Senechal (USA)

W. Steurer (Germany)

\section{Regional Associates}

\section{AMERICAN CRYSTALLOGRAPHIC} ASSOCIATION

\section{Representative}

P. W. Codding

Department of Chemistry, The University of Calgary, 2500 University Drive NW, Calgary, Alberta, Canada T2N 1N4

\section{ASIAN CRYSTALLOGRAPHIC} ASSOCIATION

Representative

J. Harada

Department of Applied Physics, Nagoya University,

Chikusa-ku, Nagoya 464-01, Japan

\section{EUROPEAN CRYSTALLOGRAPHIC COMMITTEE}

Representative

\section{A. Kálmán}

Department of X-ray

Diffraction, Central Research

Institute for Chemistry, Hungarian Academy of Sciences, POB-17, H-1525 Budapest, Hungary 


\section{Scientific Associates}

INTERNATIONAL ORGANIZATION OF CRYSTAL GROWTH

Representative

C. Paorici (Italy) (ex officio as

Chairman of the Commission on Crystal Growth and Characterization of Materials)
JOINT COMMITTEE FOR POWDER DIFFRACTION STANDARDS INTERNATIONAL CENTRE FOR DIFFRACTION DATA

Representative

R. A. Young (USA) (ex officio as Chairman of the Commission on Powder Diffraction)

\section{Representatives on bodies not belonging to the Union}

\section{ACTION COMMITTEE ON CONFERENCES OF THE EUROPEAN PHYSICAL SOCIETY}

Representative

A. Kálmán

Department of X-ray Diffraction, Central Research Institute for Chemistry, Hungarian Academy of Sciences, POB 17, H-1525 Budapest, Hungary

INTERDIVISIONAL COMMITTEE ON NOMENCLATURE AND SYMBOLS OF THE INTERNATIONAL UNION OF PURE AND APPLIED CHEMISTRY

Representative

S. C. Abrahams (USA) (ex officio as Chairman of the Commission on Crystallographic Nomenclature)

INTERNATIONAL COUNCIL FOR SCIENTIFIC AND TECHNICAL INFORMATION

Representative (appointed June 1991 to succeed F. H. Allen)

E. N. Maslen Crystallography Centre, University of Western Australia, Nedlands 6009, WA, Australia

\section{INTERNATIONAL COUNCIL OF SCIENTIFIC UNIONS (ICSU) \\ Representative}

M. Nardelli (Italy) (ex officio as Immediate Past President of the IUCr)

ISCU COMMITTEE ON DATA FOR SCIENCE AND TECHNOLOGY

Representative

F. H. Allen

Crystallographic Data Centre, University Chemical Laboratory, Lensfield Road, Cambridge CB2 1EW, England

Alternate

J. R. Rodgers CISTI, National Research Council of Canada, Montreal Road, Ottawa, Ontario, Canada K1A 0S2

ICSU COMMITTEE ON SCIENCE AND TECHNOLOGY IN DEVELOPING COUNTRIES

Representative

M. Nardelli (Italy) (ex officio as Immediate Past President of the IUCr)
ICSU COMMITTEE ON SPACE RESEARCH

Representative

C. Paorici

Physics Department, University of Parma, I-43100 Parma, Italy

ICSU COMMITTEE ON THE TEACHING OF SCIENCE

Representative

J. P. Glusker (USA) (ex officio as Chairman of the Commission on Crystallographic Teaching) 


\section{ANNEX IV}

\section{Adhering Bodies}

\begin{tabular}{|c|c|c|}
\hline Country & Category* & Adhering Body \\
\hline Argentina & I & $\begin{array}{l}\text { Consejo Nacional de } \\
\text { Investigaciones Científicas y } \\
\text { Técnicas }\end{array}$ \\
\hline Australia & III & Australian Academy of Science \\
\hline Austria & I & $\begin{array}{l}\text { Österreichische Akademie der } \\
\text { Wissenschaften }\end{array}$ \\
\hline Belgium & II & $\begin{array}{l}\text { Académie Royale des Sciences, } \\
\text { des Lettres et des Beaux-Arts } \\
\text { de Belgique }\end{array}$ \\
\hline Brazil & III & $\begin{array}{l}\text { Conselho Nacional de } \\
\text { Desenvolvimento Científico e } \\
\text { Tecnológico }\end{array}$ \\
\hline Bulgaria ; & I & $\begin{array}{l}\text { Bulgarian Academy of } \\
\text { Sciences }\end{array}$ \\
\hline Canada & III & National Research Council \\
\hline Chile & I & $\begin{array}{l}\text { Comision Nacional de } \\
\text { Investigación Cientifica y } \\
\text { Tecnologia }\end{array}$ \\
\hline $\begin{array}{l}\text { China, People's } \\
\text { Republic of }\end{array}$ & IV & Academia Sinica \\
\hline Czechoslovakia & I & Československá Akademie Vẽd \\
\hline Denmark & I & $\begin{array}{l}\text { Royal Danish Academy of } \\
\text { Sciences and Letters }\end{array}$ \\
\hline $\begin{array}{l}\text { Egypt, Arab } \\
\text { Republic of }\end{array}$ & 1 & $\begin{array}{l}\text { Academy of Scientific Research } \\
\text { and Technology }\end{array}$ \\
\hline Finland & I & $\begin{array}{l}\text { Suomen Tiedeakatemiain } \\
\text { Valtuuskunta }\end{array}$ \\
\hline France & IV & $\begin{array}{l}\text { Académie des Sciences (Institut } \\
\text { de France) }\end{array}$ \\
\hline Germany & IV & $\begin{array}{l}\text { Deutsche Gesellschaft für } \\
\text { Kristallographie }\end{array}$ \\
\hline Hungary & I & Magyar Tudományos Akadémia \\
\hline India & II & $\begin{array}{l}\text { Indian National Science } \\
\text { Academy }\end{array}$ \\
\hline Israel & I & $\begin{array}{l}\text { Israel Academy of Sciences and } \\
\text { Humanities }\end{array}$ \\
\hline Italy & III & $\begin{array}{l}\text { Consiglio Nazionale delle } \\
\text { Ricerche }\end{array}$ \\
\hline Japan & IV & Science Council of Japan \\
\hline Mexico & I & $\begin{array}{l}\text { Consejo Nacional de Ciencia y } \\
\text { Tecnologia }\end{array}$ \\
\hline Netherlands & II & $\begin{array}{l}\text { Stichting voor Fundamenteel } \\
\text { Onderzoek der Materie met } \\
\text { Röntgen- en Elektronenstralen }\end{array}$ \\
\hline
\end{tabular}

Secretary of National Committee

M. A. R. DE Benyacar, División Física del Solido, Comisión Nacional de Energía Atómica, Av. del Libertador 8250, 1429 Buenos Aires

The Executive Secretary, Australian Academy of Science, GPO Box 783, Canberra, ACT 2601

A. Preisinger, Institut für Mineralogie, Kristallographie und Strukturchemie, Technische Universität Wien, Getriedemarkt 9/171, A-1060 Vienna

G. H. Evrard, Groupe de Chimie Physique, FUNDP, Rue de Bruxelles 61, B-5000 Namur

S. Caticha Ellis, DESCM, Instituto de Física, Universidade Estadual de Campinas, Campinas, São Paulo 13100

J. MACICEKK, Bulgarian Academy of Sciences, Institute of Applied Mineralogy, Rakovsky str. 92, 1000 Sofia

J. T. SZYMAŃSKI, CANMET, Department of Energy, Mines and Resources, 555 Booth St, Ottawa, Ontario K1A 0G1

D. BoYs, Departamento de Física, Universidad de Chile, Casilla 487-3, Santiago

Xu XIAO-JIE, Department of Chemistry, Peking University, Beijing 100871

V. Petricek, Institute of Physics, Czechoslovak Academy of Sciences, Na Slovance 2, 18040 Praha 8

R. Feidenhans'L, Physics Department, Risø National Laboratory, Postbox 49, DK-4000 Roskilde

S. A. AbDel-Hady, Physics Department, Faculty of Science, Cairo Higher Institute of Technology, Helwan, Cairo

A. M. Vahvaselkä, Department of Physics, University of Helsinki, Siltavuorenpenger $20 \mathrm{D}, \mathrm{SF}-00170$ Helsinki

B. CAPElle, Association Française de Cristallographie, Tour 16, 4 place Jussieu, F-75252 Paris Cedex 05

J. FelsChe, Fakultät für Chemie, Universität Konstanz, Postfach 5560, D-7750 Konstanz 1

K. Simon, Physical Chemistry Department, Chinoin Pharmaceutical and Chemical Works, POB 110, H-1325 Budapest

P. N. Kotru, Department of Physics, University of Jammu, Canal Road, Jammu-180001

M. HAREL, Department of Structural Biology, The Weizmann Institute of Science, Rehovot 76100

G. FilipPINI, CS per le Relazionitra Struttura e Reattività Chimica, CNR, Via Golgi 19, 1-20133 Milano

M. TANAKA, Research Institute for Scientific Measurements, Tohoku University, 2-1-1 Katahira, Aobaku, Sendai 980

M. J. YACAMAN, Instituto de Fisica, UNAM, PO Box 20-364, 0100 Mexico, DF

The Executive Secretary, FOMRE, Koningin Sophiestraat 124, 2595 TM's-Gravenhage

\footnotetext{
* Adherence to the Union is in one of five Categories $1-\mathrm{V}$, with corresponding voting powers and contributions as set out in Statutes
} $3 \cdot 6,5 \cdot 5$ and $9 \cdot 4$. 


\begin{tabular}{|c|c|c|c|}
\hline Country & Category* & Adhering Body & Secretary of National Committee \\
\hline New Zealand & I & $\begin{array}{l}\text { The Royal Society of New } \\
\text { Zealand }\end{array}$ & $\begin{array}{l}\text { J. M. WATERS, Department of Chemistry, Massey University, } \\
\text { Private Bag, Palmerston North }\end{array}$ \\
\hline Norway & I & Det Norske Videnskaps-Akademi & $\begin{array}{l}\text { B. F. PEDERSEN, Institute of Pharmacy, University of Oslo, PO } \\
\text { Box 1068, Blindern, } 0316 \text { Oslo } 3\end{array}$ \\
\hline Poland & I & Polska Akademia Nauk & $\begin{array}{l}\text { A. PiETRASZKo, W. Trzebiatowski Institute of Low Temperature } \\
\text { and Structure Research, Polish Academy of Sciences, PO } \\
\text { Box 937, 50-950 Wroclaw } 2\end{array}$ \\
\hline Portugal & $\mathbf{I}$ & Sociedade Portuguesa de Física & $\begin{array}{l}\text { M. M. R. R. CostA, Departmento de Física, Universidade de } \\
\text { Coimbra, } 3000 \text { Coimbra }\end{array}$ \\
\hline South Africa & II & $\begin{array}{l}\text { Foundation for Research } \\
\text { Development }\end{array}$ & $\begin{array}{l}\text { M. J. SwiERSTRA, FRD, South Africa ICSU Secretariat, PO Box } \\
\text { 2600, Pretoria } 0001\end{array}$ \\
\hline Spain & III & $\begin{array}{l}\text { Consejo Superior de } \\
\text { Investigaciones Cientificas }\end{array}$ & $\begin{array}{l}\text { M. MARTínez RIPOLL, Instituto Rocasolano, CSIC, Serrano } \\
\text { 119, E-28006 Madrid }\end{array}$ \\
\hline Sweden & II & Kungliga Vetenskapsakademien & $\begin{array}{l}\text { R. NORRESTAM, Department of Structural Chemistry, Arrhenius } \\
\text { Laboratory, University of Stockholm, S-106 91 Stockholm }\end{array}$ \\
\hline Switzerland & II & $\begin{array}{l}\text { Schweizerische Gesellschaft für } \\
\text { Kristallographie }\end{array}$ & $\begin{array}{l}\text { G. C. Chapuis, Institut de Cristallographie, Bâtiment des } \\
\text { Sciences Physiques, CH-1015 Lausanne }\end{array}$ \\
\hline UK & $\mathrm{v}$ & The Royal Society & $\begin{array}{l}\text { The Executive Secretary, The Royal Society, } 6 \text { Carlton House } \\
\text { Terrace, London SW1Y 5AG }\end{array}$ \\
\hline USA & $\mathrm{v}$ & $\begin{array}{l}\text { National Academy of Sciences- } \\
\text { National Research Council }\end{array}$ & $\begin{array}{l}\text { D. VAN DER HELM, Chemistry Department, University of } \\
\text { Oklahoma, } 620 \text { Parrington Oval, Norman, OK } 73069\end{array}$ \\
\hline USSR & $\mathrm{V}$ & Akademija Nauk SSSR & $\begin{array}{l}\text { N. I. SOROKINA, Institute of Crystallography, Academy of } \\
\text { Sciences of the USSR, Leninsky prospekt 59, Moscow } 117333\end{array}$ \\
\hline Yugoslavia & $\mathbf{I}$ & $\begin{array}{l}\text { Jugoslavenska Akademija } \\
\text { Znanosti i Umjetnosti }\end{array}$ & $\begin{array}{l}\text { S. PoPović, Department of Materials Research and Electronics, } \\
\text { Ruđer Bošković Institute, Bijenička 54, Croatia, } 41001 \text { Zagreb }\end{array}$ \\
\hline
\end{tabular}

National Committees for Crystallography

\section{Argentina}

S. BAGGIo (Chairman), M. E. J. DE AbEledo, L. N. BECKA, D. BEDLIVY, M. A. R. DE BENYACAR, A. BonfIGLIOLI, M. BUTSCHOWSKI, E. E. GALlONI, M. IPOHORSKI, A. PODJARNY.

\section{Australia}

H. C. Freeman (Chairman), D. J. M. Bevan, R. J. Hill, C. J. HOWARD, J. W. WhITE.

\section{Austria}

A. Preisinger (Chairman), H. Heritsch, O. KratKy, H. NOWOTNY, J. ZEMANN.

\section{Belgium}

J. F. VAN LANDUYT (Chairman), F. V. DURANT (ViceChairman), S. AMELINCKX, L. DANGUY, J.-P. DECLERQ, O. DideberG, L. Dupont, G. H. Evrard, L. V. A. Fiermans, H. J. V. H. GeISE, G. S. D. KING, K. H. J. Michel, J. F. Moreau, P. Piret, H. L. Reynaers, I. J. VENNIK.

\section{Brazil}

R. Rodrigues dA Silva (Chairman), S. Caticha Ellis, J. M. Correia Neves, C. Cusatis, Y. P. MASCARENHAS.
Bulgaria

I. Kostov (Chairman), A. Apostolov, I. BoneV, J. Macíček, M. Maleev, S. Peneva, K. Petrov.

\section{Canada}

J. Trotter (Chairman), W. Anderson, G. W. Bushnell, Y. LePage, N. C. Payne, B. M. Powell, F. D. ROCHON, J. T. SZYMAŃSKi, P. S. White.

\section{Chile}

O. Wittke (Chairman), E. Besoaín, D. Boys, H. Cid, J. A. Costamagna, J. Garín, C. Infante, M. SUWALSKY, R. VERA.

China, People's Republic of

TANG YOU-QI (Chairman), FAN HAI-FU, FU HENG, HUANG JIN-LING, KUO KE-HSIN, LiANG DONG-CAI, Liang JiNG-KUI, LU JiA-XI, MiaO FANG-MING, SHAO MEI-CHENG, XU XiaO-Jie, YU Rui-huANG.

\section{Czechoslovakia}

K. HUML (Chairman), S. DuURovič (Vice-Chairman), I. Červeñ, J. Fiala, V. Holý, V. Petříček, Z. Weiss. 


\section{Denmark}

B. Lebech (Chairman), F. BRoesby-Olsen, A. N. Christensen, R. FeIdenhans'L, L. Gerward, B. Jensen, S. LARSEN, E. MAKOVICKY, P. NORBY, S. E. RASMUSSEN, N. THORUP.

\section{Egypt, Arab Republic of}

M. S. Ahmed (Chairman), Y. M. AbBas, S. A. AbDelHady, N. A. Ahmed, S. A. A. ARafa, M. A. E. EID, K. El-Sayed, I. S. Ahmed Farag, F. M. Helmi, M. RADWAN, S. A. SAlEh, Z. M. ZaGHLOOL.

\section{Finland}

K. V. J. KuRKI-SUONIO (Chairman), V. K. LINDROOS, T. L. P. PAakkari, A. V. Pajunen, J. U. Valkonen, A. I. VORMA.

\section{France}

M. Marezio (Chairman), B. Capelle, M. Frey, J. PROTAS.

\section{Germany}

J. Felsche (Chairman), J. BohM, K. Fischer, H. Höche, B. Krebs, P. Paufler.

\section{Hungary}

L. Zsoldos (Chairman), I. DÓdONY, M. FARKASJahnke, P. Gadó, I. Hargittai, A. Kálmán, L. Malicskó, K. Sasvári, K. Simon, E. Sváb, I. Viczián.

\section{India}

K. K. KanNan (Chairman), R. ChIDAMBARAM, T. N. Gururow, M. A. ItTyachen, P. N. Kotru, D. PANDEY.

\section{Israel}

J. L. Sussman (Chairman), M. Harel, M. Kapon.

$$
\text { Italy }
$$

M. Mammi (Chairman), M. Colapietro, G. Ferraris, G. Filippini, G. Gilli, S. Lagomarsino, C. MEalli, G. D. Mita, O. Moze, C. Pedone, P. Viglino, P. F. ZANAZZI.

\section{Japan}

O. NitTono (Chairman), T. AshidA, Y, Fujli, J. HARAdA, H. INOKUCHI, Fujiko IWASAKI, Hiroshi IWASAKI, Y. KaTSUBE, H. KOMATSU, T, OHACHI, Y, Ohashi, M. Ohmasa, N. Sakabe, K. Takayanagi, M. TANAKA, M. TOKONAMI, T. YamanaKa.

\section{Mexico}

M. J. YaCAMAN (Chairman), L. Baños, O. Cano Corona, Ma. A. Castellanos, A. Cordero, A. Rodríguez-Romero, J. TACHER y SAMAREL, M. DE TERESA y Carral, R. A. TOSCANo.

\section{Netherlands}

H. SChENK (Chairman), P. T. BeuRskens, J. DRENTH, D. FEIL, R. A. G. DE GRAAF, R. B. HELMHOLDT, F. TH. Hesselink, A. M. Kroon, E. J. Mittemeijer, M. G. NORTHOLT, F. TUINSTRA, J. W. VISSER.

\section{New Zealand}

G. J. GaInsford (Chairman), E. N. BAKer, C. E. F. RICKARD, W. T. ROBINSON, J. M. WATERS.

\section{Norway}

C. RøMming (Chairman), J. K. GJøNNEs, F. Grønvold, A. I. Hordvik, F. Mo, B. F. Pedersen, J. Sletten, T. G. Strand.

\section{Poland}

K. ŁUKASzewicz (Chairman), J. AULEyTNER (ViceChairman), Z. BoJARSKı, Z. GALDECKI, B. HilCZER, A. Pietraszko, J. ŻmiJa.

\section{Portugal}

M. A. Fortes (Chairman), M. M. R. R. COSTA, M. O. V. DE Figueiredo, J. LimA-DE-FARIA, R. A. QUADRADO.

\section{South Africa}

J. C. A. Boeyens (Chairman), R. B. ENGlish, J.S. Field, G. J. Kruger, M. J. LAing, L. R. Nassimbeni, J. J. Retief, M. M. Thackeray, M. J. SwiERstra.

\section{Spain}

C. Miravitlles Torras (Chaitman), M. I. ARriortua Marcaida, A. Conde Amiano, F. HERnandez Cano, M. MARTINEz Ripoll, F. SANz Ruiz, X. Solans HUGUET.

\section{Sweden}

I. Olovsson (Chairman), B. Aurivillius (ViceChairman), O. BECKMAN, C.-I. BRÄNDEN, D. CARLSTRÖM, N. INGRI, L. KIHLBORG, B. LINDQVIST, I. LINDQVist, O. LINDQVist, A. MAGNÉli, R. Norrestam, K. Sköld, B. E. StrandberG.

\section{Switzerland}

M. Dobler (Chairman), G. C. Chapuis, J. J. DAlY.

\section{LK}

R. Diamond (Chairman), P. BARnes, M. J. Begley, A. C. Bloomer, J. E. Chisholm, C. S. G. Cousins, K. M. Crenell, W. A. Gutteridge, M. Hart, J. R. Helliwell, J. I. LANGFord, A. J. SMITH, J. M. SQUire, S. E. TARling, D. J. WatKin, M. M. WOOlFson.

\section{USA}

R. F. BRYAN (Chairman), C. E. BugG (Vice Chairman), E. T. Adman, H. M. Berman, A. Clearfield, J. Deisenhofer, D. S. EgGleston, M. E. C. Etter, P. M. D. FitzGerald, J. D. Jorgensen, J. K. MOfFAT, J. L. SMITH, R. L. SNYDER, D. VAN DER HELM, B. J. WUENSCH. 
USSR

B. K. VAINSHTEIN (Chairman), V. I. Simonov (ViceChairman), K. S. Aleksandrov, L. A. Aslanov, G. B. BOKII, S. V. BORISOV, YU. N. CHIRGADZE, V. A. FRANKKamenetskil, M. A. Porai-Koshitz, R. P. Shibaeva, N. I. SOROKINA, V. S. URUSOV.
Yugoslavia

B. KAMENAR (Chairman), V. Divjaković, L. Golič, B. GrŽETa, R. HERAK, L. Karanović, B. KOJIĆ-PRODIĆ, I. Leban, S. Popović, A. Prodan, B. Ribár.

\section{Book Reviews}

Works intended for notice in this column should be sent direct to the Book-Review Editor (R. O. Gould, Department of Chemistry, University of Edinburgh, West Mains Road, Edinburgh EH9 $3 \mathrm{JJ}$, Scotland). As far as practicable books will be reviewed in a country different from that of publication.

Acta Cryst. (1992). A48, 405-406

Historical atlas of crystallography. Edited by J. LiMADE-FARIA. Pp. $x+158$. International Union of Crystallography and Kluwer Academic Publishers, Dordrecht, London and New York, 1990. Price Df 69.00 or US $\$ 36.00$ or $£ 20.00$. ISBN $0-7923$ 0649-X.

This is an unusual book, beautifully produced and packed with interest and information. It is an excellent resource book for the teaching of the history of crystallography.

It is the character of the book which is unusual. Its focal point is a set of novel displays of all the major crystallographic landmarks, plotted as a linear function of time: 'time-maps'. Hence the word 'atlas' in the title. The first of these displays, spread over a double page, maps the development of crystallography all-inclusively, from $A D$ 1500 to the present date, with superposed blue, violet, green and red colourings to show up the distinction between geometrical, physical, chemical and structural crystallography. This main time map is followed by subsidiary maps, plotting (against time) geometric, physical, chemical and structure-determination crystallography in turn, in greater detail. A few relevant landmarks in related areas of physics have been included. The unique characteristic of this form of display is the ease with which features of historical development can be grasped at sight - since the eye is such a superlatively rapid processing instrument. Thus, one can see at a glance that Leeuwenhoek was a contemporary of Huyghens; that the polarizing microscope appeared some 150 years after the wave theory of light; that Haüy preceeded Dalton by a couple of decades; and so on. Of course, the disadvantage of showing historical developments in the form of linear charts is that there is insufficient space for all the items that should really be included and even those that are included are specified telegraphically. This difficulty is made up for in the accompanying text, where a very great deal of historical detail is presented in very readable form.

The idea for this novel type of display of historical landmarks is due to Professor José Lima-de-Faria, of Lisbon. Indeed, his was the idea for the book as a whole. It was conceived primarily as an instrument for teaching, not as a definitive work of historical scholarship, and it must be understood in that light. It was in this role, as an educational resource, that the preparation of this book was sponsored by the International Union of Crystallography and, specifically, by the Teaching Commission of the IUCr. Such sponsorship gives the book a certain status; however, the Forward (by the Chairman of that Commission) makes it clear that the book is in no sense an official version of the history of crystallography, but an account which can properly be valued for the personal views of its various authors.

Mention of the 'various authors' of this book leads at once to the main criticism that must be made of this volume. It suffers from a lack of coherence. Having conceived his idea of time maps, and having worked out both their design and their textual backup, covering the past five centuries, Lime-de-Faria felt that, to fill out the details and to bring the history up to the present day, he needed the assistance of others who could write more authoritatively on specific aspects of crystallography. He therefore recruited six specialists for this, with the result that, while the book is given a lot more weight, both in pages and in scholarship (six chapters) it is also rendered patchy by these additions. Each specialist article differs in style and emphasis, giving the book a rather fragmented profile. Five of these essays are detailed histories. They deal separately with geometrical and physical crystallography (by Marjorie Senechal and W. A. Wooster, respectively), inorganic and organic chemical crystallography (by P. B. Moore and Jenny P. Glusker, respectively) and crystal structure determination (by M. J. Buerger). These have varying degrees of overlap with Lima-de-Faria's survey, naturally, but each article is manifestly self-contained, independent of the others. Each is good material, but, as one of the objects of these essays was to take the historical treatment up to the present date as far as possible, Buerger's is the least satisfactory. The sixth invited author was Helen D. Megaw, whose contribution is a short essay attempting a definition of the scope of crystallography in the context of general physical science.

In his own contribution to this book - as its principal author and as its editor - Lima-de-Faria has been generous with bibliographic information (especially) and illustrations. Indeed, we are really indebted to him for his meticulous attention to detail. A human touch is given to his chapter on time maps by the inclusion of about 100 portraits; it is followed by a list of over 500 references and, at the end of the volume, by a bibliography of some 300 entries. Elsewhere in the book there are many more lists of references and there are illustrations of classic crystallographic diagrams, early microscopes, diffraction patterns 